
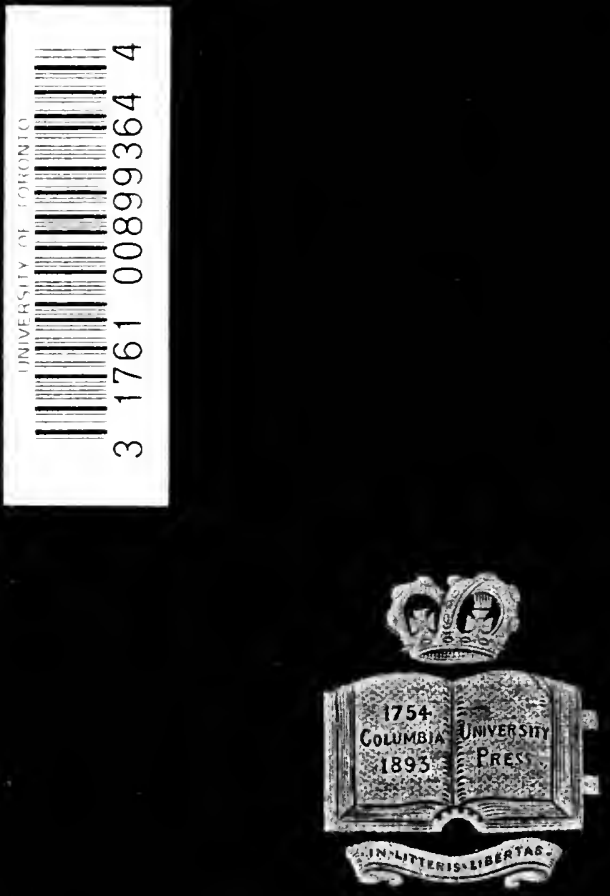



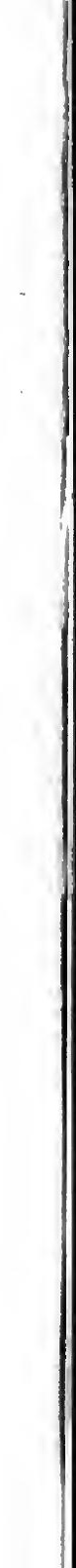




\section{Columbia aniforsity}

\section{STUDIES IN COMPARATIVE LITERATURE}

\section{THE ORIENTAL TALE IN ENGLAND}

IN THE

\section{EIGHTEENTH CENTURY}


This monograph has been recommended by the Department of Comparative Literature as a contribution to the literature of the subject worthy of publication.

\author{
J. B. FLETCHER, \\ Professor of Comparative Literature.
}




\section{THE}

\section{ORIENTAL TALE IN ENGLAND \\ IN THE}

\section{EIGHTEENTH CENTURY}

BY

MARTHA PIKE CONANT, Ph.D.

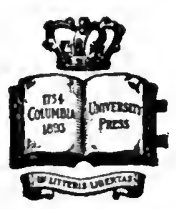

Nerw Kork

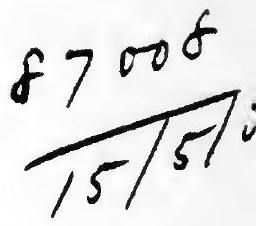

THE COLUMBIA UNIVERSITY PRESS 1908

All rights reserved 
Copyright, 1908,

By THE COLUMBIA UNIVERSITY PRESS.

Set up and electrotyped. Published January, $x 908$.

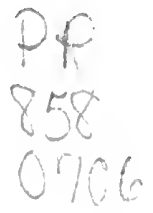

Normood 7jress

J. S. Cushing Co. - Berwick \& Smith Co.

Norwood, Mass., U.S.A. 


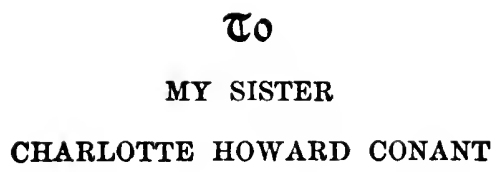




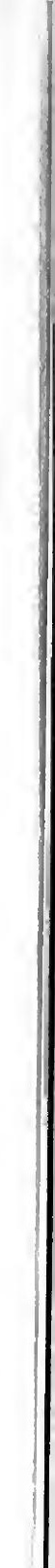




\section{PREFACE}

THIs essay is a study in eighteenth-century English literature. The author disclaims any knowledge of the oriental languages and attempts no discussion of the ultimate sources of those genuine oriental tales that appeared in English in the eighteenth century. Such a discussion is not the purpose of this study. The aim here is rather to give a clear and accurate description of a distinct component part of eighteenthcentury English fiction in its relation to its French sources and to the general current of English thought. The oriental fiction that was not original in English came, almost without exception, from French imitations or translations of genuine oriental tales; hence, as a study in comparative literature, a consideration of the oriental tale in England during the eighteenth century possesses distinct interest. Moreover the presence of this oriental and pseudo-oriental fiction in England, - as in France, - and the mingled enthusiasm and disapproval with which in both countries it was greeted, testify to the strength of established classicism and to the advent of 
the new romantic spirit. The history of the oriental tale in England in the eighteenth century might be called an episode in the development of English Romanticism.

No general survey such as the present volume undertakes, has before been made. Certain chapters in Die Vorläufer der Modernen Novelle im 18ten Jahrhundert (1897), by Dr. Rudolph Fürst, approach most nearly to the present treatment and have given valuable suggestions; H. W. Weber's Introduction to his Tales of the East (1812) contains useful data; M. Pierre Martino's work, L'Orient dans la littérature française au $X V I I^{\circ}$ et au $X V I I I^{s}$ siècle (1906), came to hand after this essay was practically completed, but has proved of distinct value; and M. Victor Chauvin's monumental Bibliographie des ouvrages arabes (1892-1905) is indispensable to any student of this subject. The Bibliography, Appendix B, II., pp. 294-306, of this volume gives the full titles of these and other books of reference to which I am indebted. None of these, however, gives anything except incidental or partial treatment of this subject. No attempt has hitherto been made to consider in a single survey all the oriental and pseudooriental fiction that appeared in England during the eighteenth century. 
It is a pleasure to take this opportunity of thanking the many friends whose assistance I have found invaluable. This book is the fruit of studies begun under the inspiration of Professor George Edward Woodberry, - an inspiration best appreciated by those students who had the rare privilege of hearing his lectures and receiving his illuminating and kindly criticism. To Dr. Frank W. Chandler, Professor of English in the Brooklyn Polytechnic Institute and formerly Instructor in Comparative Literature in Columbia University, I owe my first definite interest in the English Romantic Movement. To Dr. J. E. Spingarn, Adjunct-Professor of Comparative Literature, I am deeply indebted for friendly criticisms and counsel. To Professor Jefferson B. Fletcher, of the Department of Comparative Literature, I am especially grateful for constant assistance during the past year - assistance as generous as it was helpful; without it I could hardly have brought my work to completion. To many of my fellow-students at Columbia University I am under obligations: to Miss Mary Gertrude Cushing, now of the Department of Romance Languages and Literatures at Mount Holyoke College, for transcriptions made at the Bibliothèque Nationale, Paris; to Mr. A. D. Compton, Instructor in 
English in the College of the City of New York, for notes on certain oriental tales; to Dr. John S. Harrison, of the English Department of Kenyon College, for assistance in research; to Mr. S. L. Wolff, Adjunct-Professor of English in the University of Tennessee, for a study of oriental allusions in the eighteenth-century periodicals; to Mr. Wolff and to Dr. S. M. Tucker, Professor of English in the Florida State College for Women, for valuable suggestions. I would acknowledge also the courtesies extended by the Librarians of the British Museum, by Mr. $\mathrm{T}$. J. Kiernan of the Harvard University Library, and by the authorities of the Columbia University Library, especially Mr. Frederic W. Erb. For assistance in research at the British Museum I would thank my sister, Charlotte $\mathrm{H}$. Conant; for similar work at Harvard and in the Boston Libraries, Miss Mary H. Buckingham. Miss Buckingham enriched my initial bibliography by examining the entire Catalogue of Printed Books of the British Museum. Finally, to Dr. Duncan B. Macdonald and Dr. Edward Everett Hale I wish to express my appreciation of their kindness in lending me valuable books.

The Appendices to the present volume comprise Appendix A, Notes, chiefly concerning the indebtedness of Byron and others to the oriental 
tales; and Appendix B, I., a Chronological Table, giving full titles of the oriental tales considered, and $I I$., a Bibliography of the books of reference most useful in a study of this subject. Each book in Appendix $B, I$. and $I I$., is numbered, and will be referred to in footnotes by number when it is unnecessary to cite the full title; e.g. in the footnote on p. 2, "Cf. App. B, I., No. 4, p. 269," reference is made to the full title of the earliest known edition of the Arabian Nights, as given on p. 269. The date following the first mention of an oriental tale is, unless otherwise specified, the date of the first English edition, e.g. on p. 13, "1714" following "the Persian Tales or the Thousand and One Days." Complete lists of the oriental tales by the eighteenthcentury essayists will be found in App. B, I., e.g. No. 11, pp. 271, 272, Addison. Unknown essayists are grouped, e.g. No. 12, p. 272.

Columbia University, June, 1907. 



\section{CONTENTS}

INTRODUCTION • • • • • • $\quad \cdot \quad \begin{array}{r}\mathbf{X V} \\ \mathbf{X V}\end{array}$

CHAPTER I

The Imaginative Group $\quad$ • $\quad$ - $\quad$ - . 1

CHAPTER II

The Moralistic Group . . . . $\quad$. 73

CHAPTER III

The Philosophic Group . • • • • 112

CHAPTER IV

The Satiric Group $\quad$ • . . . 155

CHAPTER V

Literary Estimate . . . . . . 226

Appendix A. Notes • • • • • 257

Appendix B. I. Chronological Table • 267

Appendix B. II. Books of Reference • • 294

INDEX . . • • • • • • 307 


.




\section{INTRODUCTION}

IN a study of the oriental tale in England in the eighteenth century, the high lights fall upon the Arabian Nights, Dr. Johnson's Rasselas, Goldsmith's Citizen of the World, and Beckford's Vathek. The present volume aims to depict clearly the interesting orientalizing tendency of which these apparently isolated works were the best manifestations - a tendency itself a part of the larger movement of English Romanticism. By "the oriental tale in England" I mean all the oriental and pseudo-oriental fiction - chiefly prose - that appeared in English, whether written originally in English or translated from the French. Much of the fiction I-shall consider deserves distinctly to be called pseudo-oriental, Rasselas, for instance, and The Citizen of the World; on the other hand, much of it, such as the Arabian Nights and kindred literature, is genuinely oriental despite its eighteenth-century dress. By "oriental" I mean pertaining to or derived from "those countries, collectively, that begin with Islam on the eastern Mediterranean 
and stretch through Asia," 1 with - so far as this specific treatment of the subject goes - one notable exception, Palestine. To the Western mind to-day the Holy Land occupies, as Professor Pierre Martino has pointed out, a unique position somewhat apart from other oriental countries, a position which is of course due to the inherited traditions of Christianity. ${ }^{2}$ In the eighteenth century this feeling was far more pronounced than it is in these days of modern scholarship; and therefore, from the eighteenthcentury "oriental" literature under consideration we may legitimately exclude Hebrew literature and its imitations. "Oriental," then, includes here what it included according to Galland, the first translator of the Arabian Nights into French : "Sous le nom d'Orientaux, je ne comprends pas seulement les Arabes et les Persans, mais encore les Turcs et les Tartares et presque tous les peuples de l'Asie jusqu'à la Chine, mahométans ou païens et idolâtres." 3

${ }^{1}$ Standard Dictionary of the English Language, Vol. II., New York, London, and Toronto, 1895.

${ }^{2}$ Martino, Pierre, L'Orient dans la littérature française au XVII' et au XVIII's siècle, Paris, 1906, p. 20.

${ }^{3}$ Galland, Paroles remarquables des Orientaux, Paris, 1694, Avertissement, quoted by P. Martino, op. cit., p. 221. 
The scope of our subject in time is less readily defined; since, as in the case of most literary tendencies, both beginning and end were gradual and transitional. The prelude was sounded in the late seventeenth century by the first English translation of Marana's satire, The Turkish Spy. Yet, broadly speaking, the period began between the years 1704 and 1712, with the first English version of the Arabian Nights, a book so different in character from any oriental fiction then known in England, and so far-reaching in influence, that it forms the natural point of departure. The period drew to a close with the advent of the more modern and scholarly translations of various works made directly from oriental languages, which influenced later the poetry . of Southey, Moore, Byron, and others. For the approximate date we may tak 1786. In that year was published Vathek, ${ }^{1}$ the last notable oriental tale of the century, itself foreshadowing the coming work of scholars and poets. Only two years earlier Sir William Jones, the great orientalist, had given his inaugural lecture as first president of the Asiatic Society of Bengal. Yet the date $\mathbf{1 7 8 6}$ is approximate only; for in ${ }^{1}$ Cf. App. B, I., No. 73, pp. 288, 289. 
the sixties and seventies, some direct translations were made; and in the eighties and nineties oriental tales appeared, so similar in character to those of this period that they must logically be included. For the period as a whole, despite the transitional nature of the beginning and the end, has a distinctive character. It is obviously different from the period that followed. The latter, beginning with the direct translations by orientalists, has, from the days of Sir William Jones to those of Kipling, been characterized by an increasing knowledge of the Orient at first hand. By travel and residence in the East, by contact with Eastern peoples, as well as by study of oriental history, literature, and philosophy, Englishmen of the nineteenth and twentieth centuries have learned to know more of the "inscrutable Orient" than their ancestors of the eighteenth century ever imagined possible. ${ }^{1}$ This fact at once and radically differen-

${ }^{1}$ Cf. F. Brunetière, Études critiques sur l'histoire de la Littérature française, huitième série, Paris, 1907: L'Orient dans la littérature française, p. 183: "Schopenhauer," dont la philosophie n'est elle-même qu'un bouddhisme occidental, a écrit quelque part, en 1819 ou 1822, que 'le $\mathrm{XIX}^{\circ}$ siècle ne devrait guère moins un jour à la connaissance du vieux monde oriental que le XVIe siècle à la découverte ou à la révélation de l'antiquité grécoromaine.'" 
tiates these later centuries from the period we are to consider. A brief glance over the history of oriental fiction in England previous to the eighteenth century will make the distinction equally clear from that side.

Oriental fiction had been borne to England from an early period by various waves of influence. As far back as the eleventh century, fictitious descriptions of the marvels of India are found in Anglo-Saxon translations of legends concerning Alexander the Great. During the Middle Ages many Eastern stories drifted across Europe by way of Syria, Byzantium, Italy, and Spain. Merchants and travelers like Marco Polo, missionaries, pilgrims, and crusaders aided the oral transmission of this fiction; and scholärs gave to Europe Latin translations of four great collections of genuine oriental tales: Sendebar; Kalila and Dimna, or The Fables of Bidpai; Disciplina Clericalis; and Barlaam and Josaphat. A definite, though not large, share in this treasure-trove fell to the lot of England and appeared in the form of metrical romances, apologues, legends, and tales of adventure. The fabliau of Dame Siriz, The Proces of the Sevyn Sages, Mandeville's Voiage, Chaucer's 
Squier's Tale,-possibly several other Canterbury Tales, - are typical instances.

In the sixteenth century, that great period of translation, were published the first English editions of the Gesta Romanorum and of the Fables of Bidpai, the latter entitled The Morall Philosophie of Doni . . . englished out of Italian by Thomas North . . . (1570). During the reign of Elizabeth an entirely new line of intercourse between England and the East was established by the voyages of exploration, discovery, and commerce, characteristic of the Renaissance. Moreover, since the Fall of Constantinople (1453), the Turks had been an increasing menace to Europe. Their ascendancy culminated in the reign of Soliman the Magnificent (1520-1566), and their continual advance upon Christendom was checked only by their great defeat at the battle of Lepanto (1571). Throughout the century, as a natural result of these events and of the voyages referred to above, interest was aroused in oriental - especially Turkish -- history and fiction. In Painter's Palace of Pleasure, for instance, we find the stories Mahomet and Irene, and Sultan Solyman; in the drama such plays as the Soliman and Perseda, usually as- 
cribed to Kyd; Alaham, and Mustapha, by Fulke Greville, Lord Brooke; and Marlowe's Tamburlaine. In Shakespeare's plays, one incident, The Induction to the Taming of the Shrew, has been traced with a good deal of plausibility to Eastern fiction; otherwise, his works show no oriental elements of importance. "The farthest steep of India" as a part of Oberon's fairy kingdom is possibly drawn from Lord Berners's prose version of Huon of Bordeaux. That the scene of Antony and Cleopatra is partly in the East does not make it anything but a Roman play.

In the seventeenth century, interest in the Orient was shown by the works of travelers, historians, translators of French heroic romances, dramatists, and orientalists. Knolles's famous Generall History of the Turks appeared in 1603, a result of the new interest in Turkey mentioned above, and itself a notable factor in extending that interest for years to come. Toward the middle of the century the pseudo-oriental heroic romances of Mlle. de Scudéry and others were translated and won great popularity. After the Restoration numerous heroic plays on similar subjects followed in rapid succession. A few 
of these heroic romances were reprinted in the eighteenth century and thus form one link between the fiction of the two periods. Another link is Sir Roger L'Estrange's version of The Fables of Bidpai.' Still another is the Latin translation by Edward Pococke (1648-1727), son of the Oxford orientalist, of the Arabian philosophical romance Hai Ebn Yockdhan, which appeared first in English in the eighteenth century. Marana's Turkish Spy has already been mentioned as a late seventeenth-century prelude to the oriental tale of our period.

Such was the oriental fiction that had entered England previous to 1700 , and had contributed to a more or less vague and general imaginative acquaintance with the Orient. The sudden advent of the Arabian Nights, full of the life, the colour, and the glamour of the East - even in the Gallicized version of Antoine Galland naturally opened a new chapter in the history of oriental fiction in England.

The same had been true in France; in fact, the entire English movement echoed to a certain extent the similar French movement. That, also, - preluded by The Turkish Spy,-was

${ }^{2}$ Cf. pp. 104, 105, and App. B, I., No. 10, p. 271, post. 
inaugurated by the Arabian Nights, first introduced into Europe by Galland in the famous translation just referred to. Meeting with instant and great - though not unanimous favour, the Arabian Nights was followed at once by the equally popular translations by Pétis de la Croix, L'histoire de la Sultane de Perse et des Vizirs, Contes Turcs (1707), and Les Mille et un Jour [sic], Contes Persans (1710-1712). The time was ripe in France for this new literary material. At the beginning of the new century there were especial reasons for the welcome given to oriental stories and to Perrault's fairy tales, the chief reason being a natural reaction from the dominant classicism of Boileau. From Fairyland and the Far East two streams began to flow into the main current of French Romanticism. The romanticists of that day went wild over the fascinating tales of "merchants, cadis, slaves, and calendars," in a manner foreshadowing the nineteenth-century romanticists who enthusiastically welcomed Les Orientales.

Moreover, interest in the Orient had been growing throughout the seventeenth century in connection with the colonial and commercial expansion of France in the reign of Louis XIV. 
Merchants, Jesuit missionaries, travelers, and ambassadors had returned with information and entertaining or tragic stories. ${ }^{1}$ Galland and Pétis de la Croix, in their turn, found an enthusiastic reception. ${ }^{2}$ Their collections were succeeded by a swarm of preposterous imitations, such as those of Gueullette, pretending also to be translated from oriental manuscripts and catering to the inordinate popular demand for things oriental. Fantastic elements from the fairy tales of Perrault and his successors were mingled with the extravagances of oriental stories, until the torrent of enthusiasm rapidly spent its force and left several new channels open to French fiction. Satire on both oriental tales and fairy stories inevitably appeared, and proved a sharp weapon in the hands of Hamilton, Caylus, and a score of others. Philosophical satirists like Montesquieu (Lettres Persanes, 1721) found the oriental tale a convenient medium for scarcely veiled criticism of French society; and the versatile genius of Voltaire perceived

${ }^{1}$ M. de Cézy, French ambassador to Constantinople, thirty years before Racine's Bajazet, brought the original story to Paris. Cf. P. Martino, op. cit., p. 196.

${ }^{2}$ Galland and Pétis de la Croix both went to the East with embassies. 
the latent capabilities of this fiction as a vehicle for philosophy as well as for satire. The coarseness present in many oriental tales, even in Galland's expurgated and Gallicized Arabian Nights, undoubtedly afforded to Crébillon fils, and others, a starting point for their numerous contes licencieux, which satirized the extravagance of the fairy stories and the oriental tales and ridiculed the moralizing tendency as well. The latter propensity was prominent in France toward the middle of the century, witness the numerous works of Marmontel, the founder of the so-called conte moral, or tale of manners and morals. Three of his tales are oriental in setting. Parody and the use of the genre as a vehicle for satire and didacticism assisted its decline.

In England the general development of the oriental tale was similar, partly because of the direct influence of numerous translations from the French and partly because of the presence of tendencies in England analogous to those in France. The propensity to moralize and to philosophize, the love of satire, and the incipient romantic spirit, were common to both countries, although present - as we shall see - in vary-i 
ing degrees. In England this fiction falls naturally into four groups, - imaginative, moralistic, philosophic, and satiric. The imaginative group, the earliest, and, at the beginning of the century, the most significant, diminished as the other groups increased in strength, but revived again near the end of our period in Beckford's Vathek. The moralistic and philosophic groups are prominent in the periodical essays from Addison to Dr. Johnson. The philosophic group comprises besides Rasselas several translations from Voltaire's contes philosophiques. The satiric group is chiefly exemplified by the pseudo-letters culminating, in English, in Goldsmith's Citizen of the World, and by Count Hamilton's entertaining parodies. One work, indeed, belonging in the imaginative group, was influential throughout the whole period: the Arabian Nights - as numerous editions testify - was a permanent factor in the development of the oriental tale in England.

Chapters I., II., III., and IV. of this volume will be devoted to a description of the most important characteristics of these successive groups, and the final chapter will present a literary estimate of the genre as a whole. 


\section{THE ORIENTAL TALE IN ENGLAND}

\section{CHAPTER I}

\section{THE IMAGINATIVE GROUP}

OF all the wide lands open to the wandering imagination none has a more perennial charm than the mysterious East. To that magical country the Arabian Nights, ever since its first appearance in English in the early years of the eighteenth century, has proved a favourite gateway, over which might well be inscribed:-

"Be glad, thou reder, and thy sorwe of-caste, Al open am I; passe in, and hy the faste!"

With the exception of the Hebrew Scriptures, the Orient has given us no book that has become so intimate a part of our imaginative inheritance. "Aladdin's lamp," the "Open Sesame," "changing old lamps for new," "the Old Man of the Sea," have entered into familiar houschold speech. Many a reader has echoed the mood of Haw- 
thorne, "To Persia and Arabia and all the gorgeous East I owed a pilgrimage for the sake of their magic tales." 1

It would be superfluous to describe this familiar book in detail. That ground has been well covered by such translators and essayists as Sir Richard Burton and Mr. John Payne. Our purpose is rather to examine briefly the general character of the Arabian Nights ${ }^{2}$ in order to understand the significance of its sudden entrance into the England of Queen Anne. The earliest collection of oriental tales to appear in English in the century, it is also the richest in pure imaginative power and therefore has a twofold right to first consideration in this chapter.

One of the chief elements of charm in the Arabian Nights has already been suggested the sense of mystery and magic. The arrangement of the stories enhances this impression. At first glance the form seems simple. The frametale, that well-known device believed to be of oriental origin, is the story of the beautiful Scheherezade telling tales to the cruel sultan

${ }^{1}$ Nathaniel Hawthorne, by G. E. Woodberry, in the American Men of Letters Series. Boston and New York, 1902, p. 54 ; cf. p. 12.

${ }^{2}$ Cf. App. B, I., No. 4, p. 269. 
for a thousand and one nights. But within this simple setting the stories are so interwoven and so varied - apologues, romances, anecdotes, and fables - that the total effect is as intricate as the design of an oriental carpet. One strange story follows another in bewildering profusion until the reader seems to be walking in a dream "in the days of Haroun Alraschid," when the unexpected always happens. In this land of wonder and enchantment any threatening cloud may assume the form of an enormous genie, white-bearded, terrific, with torch in hand and a voice like thunder, "a Slave of the Lamp," ready to carry a sleeping prince a thousand leagues through the air or to erect over night a palace of dazzling splendour; any serpent may be an enchanted fairy; any beautiful woman may be a disguised princess"or a cruel sorceress with power to transform human beings into dogs or black stones; and at every turn one may meet African magicians who can pronounce the "Open Sesame" to subterrancan treasure-caves. In the bazaars fairies disguised as old women sell magic carpets to fortunate princes; by the wayside an aged dervish sits for the sole purpose of directing seekers toward the talking bird, the 
singing tree, and the yellow water. "The wondrous horse of brass" is no more marvelous than the roc, "a white bird of monstrous size and of such strength that it takes elephants from the plains to the tops of the mountains." In the world of the Arabian Nights is to be found the magic mirror that reveals character by remaining

- unsullied only in the presence of the pure in heart. On the sea furious storms arise and drive ships to sure disaster against the black mountain of adamant. Shipwrecked Sindbad meets strange dwarfs; "tremendous black giants, one-eyed and as high as a tall palm-tree"; and, most dangerous of all, the terrible Old Man of the Sea. Shark-headed monsters and beautiful mermaids arise from the deep; and, if one could only look down far enough, one would see in the ocean depths vast kingdoms of boundless wealth and unutterable beauty, ruled over by the flamebreathing princes of the sea. In these enchanted domains it is not surprising to find superlatively horrible monsters "with the head of an elephant and the body of a tiger" ; or to encounter blinding flashes of lightning, "followed by most tremendous thunder, ... hideous darkness, ... a dreadful cry, ... and an earthquake such as 
Asrayel is to cause on the day of judgment." The same naive love of magical unreality that adorns these stories with such transcendent horrors produces the scenes of "surpassing beauty," which have made the splendour of the Arabian Nights proverbial." Aladdin's magnificent palace - jeweled windows and all - 1 is eclipsed by the palace of the third Calendar, "more splendid than imagination can conceive."

And yet, despite all this misty atmosphere of wonder and magic, there is in the Arabian Nights a strange sense of reality in the midst of unreality, a verisimilitude which accounts in large part for the steady popularity the book

1 Proverbial despite the "extreme simplicity of its style," noted by Mr. John Payne, Vol. IX., pp. 373,375, of his edition of The Book of the Thousand Nights and a Night. London, 1884. "Nothing can be more unlike the idea of barbaric splendour, of excessive and heterogeneous ornament, that we are accustomed to associate with the name, than the majority of the tales that compose the collection. The life described in it is mainly that of the people, those Arabs so essentially brave, sober, hospitable, and kindly, almost hysterically sensitive to emotions of love and pity as well as to artistic impressions.

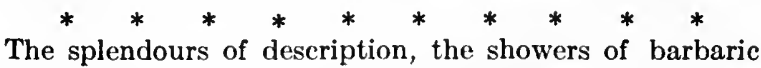
pearl and gold, that are generally attributed to the work exist but in isolated instances. The descriptions are usually extremcly naĩve." 
has enjoyed with the English people. The cities of Bagdad and Cairo, the countries of the East, the Seven Seas, are real places, though so far away that they seem on the borders of fairyland. Time as well as space is an actuality, however remote and vague. Plausible introductory phrases imitate the manner of a veracious historian, e.g., "There was a Sultan named Mirza who had peaceably filled the throne of India many years." It is easy for the reader to imagine himself present at the scenes described, e.g., the opening of the divan of the mock caliph in the Sleeper Awakened, when "the grand vizier Giafar and the judge of the police ... first bowed themselves down before him and paid him the salutations of the morning." In the bezesteins silk merchants, glass dealers, and jewelers sit by their wares and fall in love with veiled ladies; venders of roses, dervishes, and beggars crowd past; and dogs who may be enchanted princes tell false coin from true to the delight of the lookers-on. At the water-gate of the palace on the Tigris, the favourite slave of the sultaness Zobeide outwits the crabbed old eunuch and secures safe admission for the trunk containing her lover. 
Prince Houssain tells us travelers' tales of the brazen temple in which "the principal idol was ... of massive gold; its eyes were rubies, so artificially set, that it seemed to look at the spectator in whatever direction he stood." When the king of Serendib appears in public, he has a throne fixed on the back of an elephant and is surrounded by attendants clad in silk and cloth of gold; "and the officer before him cries out occasionally, 'Behold ... the potent and redoubtable sultan of the Indies, whose palace is covered with an hundred thousand rubies, ... greater than the greatest of princes!' After which the officer who is behind cries out, 'This monarch, so great, so powerful, must die, must die, must die.' The officer who is before replies, 'Praise be to him who liveth forever.'" 1

Other customs are described in equally vivid detail. The obsequies of a prince include long processions of lamenting guards, anchorites, and maidens; marriage ceremonies are accompanied by feasting, music, dancing, and the bride's seven-fold salutation of her husband. "The pure religion of our holy prophet" is contrasted with the cruel rites of fire-worshipers.

${ }^{1}$ Cf. Rambler, No. 17. 
Devout Mussulmans pass through the streets to the mosques and make pilgrimages to Mecca.

But of all the glimpses of Eastern life the most interesting is the constantly recurring picture of the oriental story-teller. Everywhere-in the bazaars, by the wayside, in palace gardens or fishermen's cottages, during the feasts or before the caliph's tribunal, by night and by day the teller of tales is sure of an interested audience. The variety of stories in the Arabian Nights makes credible the theory of recent editors, that the ultimate sources were equally diverse, - an hypothesis that goes far toward explaining the artistic excellences and limitations of the collection.

What wonder that, with listeners clamouring like children for another story, each narrator exerted his ingenuity to outdo his predecessors and, like Scheherezade herself, promised greater marvels next time? In most of the tales one surprising adventure succeeds another with kaleidoscopic rapidity, unconnected except by the mere presence of the hero. In that respect these tales resemble the modern historical romance. The chief appeal is to the listener's or reader's curiosity, and little thought is given 
to the structural unity of the narrative. There is a succession of events, but rarely any causal sequence. Even in so capital a story as Aladdin the two elements of the climax-Aladdin's marriage and the magician's resolve upon vengeance-are loosely knit by chance and by magic. The close of the average story is usually as movable a point as the climax. If the narrator thinks of another incident, he merely adds a postscript. Witness the Story of the Barber's Sixth Brother, in which the misfortunes of Shacabac after the Barmecide's death are foisted upon the admirably dramatic tale of the Barmecide's feast.

But, though the majority of the tales possess little structural unity, many individual incidents are perfect dramatic sketches, cleverly introduced, wrought to a climax, developed to a dénouement, and characterized by compression and rapid movement no less than by brilliant descriptive phrases and good dialogue. Such are the disastrous day-dream of Alnaschar the glass merchant, the adventure of the barber's blind brother, and the ruse of Abon Hassan and his wife to win gifts from the caliph and Zobeide by feigning death. ${ }^{1}$ The dénouement of the last

${ }^{1}$ The Story of the Sleeper A wakened or The Dead Alive. 
will readily be recalled. The perplexed caliph offered a thousand pieces of gold to any one who could prove which of the two, Abon Hassan or his wife, died first. "Instantly a hand was held out, and a voice from under Abon Hassan's pall was heard to say, 'I died first, Commander of the Faithful, give me the thousand pieces of gold." 'This dramatic instinct for situation or incident is especially noticeable in the numerous clever introductions. The favourite device of the disguised caliph Haroun wandering through the city in search of adventure never fails to awaken interest. Mysterious scenes of grief or sudden exclamations stimulate curiosity at once. "'For God's sake, sir,' replied the stranger, "let me go! I cannot without horror look upon that abominable barber!"”

Beyond incident and situation, however, the dramatic instinct of the story-teller does not go. He shows little psychological insight. His characters are wooden automata, picturesque truly, but neither individualized nor alive. Various figures recur repeatedly: the prodigal youth, forsaken by his fair-weather friends; the tyrant sultan; the clever man; the superlative hero; the unjust judge; good and bad 
viziers; and good and bad sons. They might be shifted from one story to another with no more shock than Aladdin's palace felt when lifted and set down again. The Arabian Nights contains, fortunately, little or no direct moralizing, but in these abstract types it offered suggestions not lost upon the eighteenth-century writers of moralistic oriental tales. Even familiar figures like Aladdin and Sindbad owe their existence as individuals to the reader's sympathetic imagination. They are interesting, not in themselves, but on account of their marvelous adventures.

For, after all, one supreme attraction of the Arabian Nights is the charm of pure adventure, the story for the sake of the story. Sentimental tales are exceptional; in only eight is love the chief interest. Adventurous tales of the Sindbad type are more eharaeteristic. It is noticeable that in many of the stories where picaresque or farcical realism is strong, magic plays no part. But in all the tales, whether. magical or realistic, the emphasis is thrown on events. Exeiting incidents are given verisimilitude by picturesque details, until the reader, forgetting for the moment the absenee of the 
deeper realities of character, comes under the spell of pure romance, - as in the case of Robinson Crusoe, the novels of Dumas, or the folk-ballads, - and must himself "mitdichten." The magical atmosphere, the rich variety of dramatic incident, the spirit of adventure, and the brilliant background, atone in part for the lack, in the Arabian Nights, of structural unity and characterization. Across the scene moves the seemingly endless, ever shifting pageant of dramatis personce, all sorts and conditions of men: princes and viziers, ropemakers and fishermen, dervishes and cadis, sheiks and slaves, queens and beggar-women. One can see them, hear them speak, and guess at their characters as one might in observing passers-by in the bazaars of some strange Eastern city. For the time being it is easy to follow Ali Baba to the forest to gather wood; or to share the fright of the fisherman who liberates the genie; or to hear the tired porter Hindbad railing at Fortune as he rests in the cool street sprinkled with rose-water, while the whitebearded, travel-wise Sindbad listens from his palace window and summons the poor man in; or to feel the human interest in the dramatic 
scene that serves as the general background Scheherezade saving the lives of her countrywomen by telling her tales to the sultan.

The collection of oriental tales next in order of importance is the Persian Tales or the Thousand and One Days ${ }^{1}$ (1714), the companion-piece to the Arabian Nights. The plan is similar: a frame-tale which introduces and concludes the collection and links the successive stories. But in the Persian Tales, instead of a sultan who has lost faith in women, the central figure is the princess of Casmire, who, having dreamed that she saw an ungrateful stag forsaking a hind, has lost faith in men and has decided never to marry. Her beauty drives men mad; the king, her father, is in despair; and her old nurse, Sutlememé, undertakes to convert her by tales of faithful lovers. For a thousand and one days the tales are told, but each hero is criticized by the skeptical and obdurate princess. She is finally persuaded to marry the prince of Persia only by the magic powers and religious authority of a holy dervish. The conclusion of the frametale is unnecessarily complicated by the introduction of the witch Mehrefsa, a Persian Circe.

${ }^{1}$ Cf. App. B, I., No. 15, p. 273. 
There is at the close an attempt to recall the introduction by the story of the prince's dream that the princess, "fairer than a houri," appeared to him in a flowery meadow and told him of her dream and conscquent loss of faith in mankind. But this incident gives only a superficial unity to the frame-tale; structural unity is lacking. The same criticism holds true of the majority of individual stories in the Persian Tales. Considerable unity of feeling, however, is given to the collection by the fact that Sutlememé's avowed purpose holds her chiefly to one theme, true love, - which often rises above the sensuous or the ridiculously sentimental and throws a pleasant light over the stories as a whole.

This characteristic differentiates the Persian Tales at once from the Arabian Nights. For instance, a typical story in the Persian Tales begins as follows: the hero, Couloufe, a youth of noble birth, having wasted his substance, wanders to a far-off city. A mysterious slave in the bazaar beckons him. He follows into a palace; enters one hall after another, each more glorious than the last; and beholds pillars of "massy gold," silver trees with emeralds for leaves, singing birds behind golden lattices, 
fragrant roses growing around marble basins of crystal water, banquets on sandalwood tables, little pages offering wine in cups made of single rubies; and, finally, the princess arrayed in "rose-coloured taffeta, thick-sown with pearls," seated on a golden throne, surrounded by "radiant damsels" singing to the lute or dulcimer, "Love but once, but love forever." "Couloufe imagined that he saw the moon surrounded by the stars, and fainted, quite overpowered with the sight of this ravishing object." To faint seems, in fact, the customary mode of showing affection. In another tale, the heroine on the slightest provocation melts into "floods of tears" and the hero is not far behind with his tears and swoons. Reproached by his mistress, he says, "It struck me to my very soul, and in the height of my grief ... I fell into a fit and swooned away at the foot of the throne." Violent agitation, "a languishing air," transports of passion or of wrath, remorse which causes death, call to mind the eighteenth-century novel of sentiment.

More sentimental than the Arabian Nights, the Persian Tales is also more fantastic. The talking bird of the prophet Isaac, which came 
to aid Aboulfouaris on the desert island, had a blue head, red eyes, yellow wings, and a green body. We are not surprised when the hero says, "I had never seen one like it." This remarkable bird is, however, eclipsed in the same story by an ugly Afrite with a nose like an elephant's trunk and with one eye blood-red, the other blue, who led Aboulfouaris past roaring lions, huge dragons, and fierce griffins. The Afrite and the griffins themselves seem commonplace beside the prophet Elias, who is pictured as a cavalier wearing a green turban set with rubies and riding a rose-coloured horse under whose feet the earth immediately produces flowers. In describing scenes of beauty or of horror the Persian Tales is far more lavish than the Arabian Nights. The princess Tourandocte, asking riddles of Prince Calaf, "not satisfied with putting this question to him, ... maliciously threw off her veil, to dazzle and confound him with the luster of her beauty. Her despite and shame [at his having guessed her other riddles] had given her a blush which added new charms, ... her head was adorned with ... flowers; . . . and her eyes shone brighter than the stars, brighter than the sun when he shines in his full glory at the open- 
ing of the black eloud. The amorous son of Timurtasch, at the sight of this incomparable prineess ... stood mute." Scenes of horror are equally marvelous. The Persian Old Man of the Sea, for instance, is a huge monster with tiger's eyes and an impenetrable skin, who meets his death only by battling with "the greatest roc that was ever seen."

Like the Arabian Nights, the Thousand and One Days carries us to a land of magic and enchantment. There we find the magic mountain of polished steel which draws all ships to it with fatal power; the ring with Solomon's seal; and the magic chest that transports its occupant through the air when guided by pressure of certain springs, like the horse of brass. There are bad genii, black and lean with sparkling eyes and horns; and there are good spirits, clothed in white like "religious Sophis." There are magicians like the witch Bedra, who sits in a dismal cavern with a great book open upon her knees, in which she reads before a furnace of gold, wherein there is a pot of silver, full of black earth that boils without fire. Caverns of treasure eontain kings and princesses in magie sleep. One amusing variation from the ordinary treas- 
ure-cave is the cavern of books. Avicena, the sage, says: "Towards the Caspian Sea there is a mountain which is called the Red Mountain, because it is covered with roses throughout the year." At the foot is a cavern of vast extent, the doors of which by virtue of a talisman open once a year of their own accord and shut again in half an hour and fifteen minutes, and if "any bookish man, too intent upon his choice of authors," stay, he is sure to be starved to death. "The wise Chec Chehabeddin" gathered there twenty thousand books, which treat of the philosopher's stone, of the method of discovering hidden treasure, of changing men into beasts, and of giving souls to vegetables: "all the secrets of nature." 1 Apparently this remarkable library was carefully catalogued and efficiently watched by genii, who seized all persons that neglected to return books and "tormented them cruelly, ... even to death." 2

${ }^{1}$ The Persian Tales, in Tales of the East, edited by Henry Weber. Edinburgh, 1812, Vol. II., p. 455.

${ }^{2}$ Washington Irving eompares the reading-room of the British Museum to the scene in "an old Arabian tale, of a philosopher who was shut up in an enchanted library, in the bosom of a mountain, that opened only once a year; where he made the spirits of the place obey his 
One of the greatest charms of the Persian Tales, as of its better-known rival, lies in the mingling of reality and unreality. Genuine glimpses of oriental eustoms and beliefs alternate with strange adventures. The scenes are laid in real places, but the Eastern names have a magic all their own. We see Aboulfouaris, "the Great Voyager," sailing down the Gulf of Basra, between Persia and Araby the Blest, toward Ormus and the kingdom of Indes. It is easy for the fancy to fly as on a magic carpet from the vale of Cashmere, from Carisme and Candahar to Golconda and Samarcande; or to sail past China to the Isle of Cheristany till our ship drives "to the Strait of the Moluccas, south of the Philippines into seas unknown to our mariners."

Strange customs are described with a lavish and yet plausible use of detail. The throne of the king of China was "made of Catai steel in the form of a dragon, about three cubits high;

eommands, and bring him books of all kinds of dark knowledge, so that at the end of the year, when the magic portal once more swung open on its hinges, he issued forth so versed in forbidden lore, as to be able to soar above the heads of the multitude and to control the powers of Nature."-The Art of Bookmaking, in the Sketch-Book. 
over it was a canopy of yellow satin adorned with diamonds supported by four lofty pillars of the same Catai steel." The king, when disposed "to take the diversion of fowling, ... was clothed in a straight caffetan, and his beard was tied up in a black bag." Grief of the Chinese courtiers for their king's death was expressed by dyeing their faces yellow and strewing rose leaves before the throne. In the story of Aboulfouaris's first voyage occurs an elaborate description of the suttee - the funeral pyre, the ablutions, the gorgeous apparel, and the voluntary suicide of the widow.

Other customs described are masquerades, visits, and feasts. On one festival night fireworks were set off, sherbets and sweetmeats were offered to every one, dancing to the tambours and deffs took place in the square, and "Calenders ran to and fro in the street like men transported with frenzy." "The shops in all the great streets and squares were hung with tapestry ... illuminated with sashes that contained some verse out of the Alcoran; . . . the sacred book might be read entire as you walked the streets. It seemed as if the Angel Gabriel had brought it down to our great prophet a second 
time in characters of light." The most binding oath is, "I swear by the black stone of the sacred temple of Mecca and by the holy grove of Medina, where the tomb of our prophet lies." "There is no other God but one, and Mahomet is his prophet." Belief in the divine pen of fire that writes on a tablet of light is referred to in the story of Couloufe. "I know not whether God wills that I die or live for you, but at least I know well that it will never be written in heaven that I shall repudiate you." There are several curious references to Eastern philosophies, e.g., the captive princess who has just stabbed herself says: "[I learned in infancy] the doctrine of Xaca, and you need not then wonder I had the courage to do this. I am returning to my original nothing." The king replies, "May you ... after having passed through the nine hells, be born again daughter of another sovereign as at the first transmigration." In the tale of Fadlallah and Zemroude the idea of transmigration is prominent.

Scattered through the Persian Tales are incidents and phrases suggesting familiar European stories. It is interesting to note the resemblances, but impossible to say whether the original source 
was oriental or European. ${ }^{1}$ For instance, this version of the Ballad of the Heir of Linne occurs. Atalmulc, the spendthrift son of a rich jeweler, had been told by his dying father that after he had wasted all his patrimony, he should tie a rope to the branch of a certain tree in the garden and "prevent the miseries of poverty." Atalmulc, thinking his father had suggested suicide, endeavoured to hang himself. The branch broke, disclosing the careful father's hoard of jewels. In the story of King Ruzvanchad the king marries the princess of the genii with the promise never to reprove her, but to say, "She is a genie and has special reasons for her actions." $\mathrm{He}$ breaks his promise, after great provocation; and she vanishes, to return after ten years to reward his constancy. There is a resemblance here to the story of Undine. Both tales, like Lohengrin and Cupid and Psyche, are variants on the world-wide theme: Lack of faith means loss of love. Other incidents in Ruzvanchad might find parallels in Celtic, or Teutonic, or Greek legends. The king meets a white doe, "beautifully sprinkled with blue

${ }^{1}$ It is particularly difficult in the case of the Persian Tales, because Le Sage "revised" the manuscripts. 
and black spots; with rings of gold upon her feet; and upon her back a yellow satin, bordered round with embroidery of silver." She disappears into a fountain; the king, thinking her a nymph in disguise, falls asleep to be awakened by "a ravishing symphony" coming from "a very magnificent palace all illuminated," which has been raised by superhuman power. Later he finds a melancholy lady in torn garments, who says: "I am the daughter and the wife of a king, and yet not what I say. I am a princess, and yet not what I am." Her misfortunes prove to be due to the machinations of a witch who, Duessa-like, has assumed her form and won away her husband. In the History of Two Brothers, Genies [sic], Adis and Dahy, a tale in some respects coarse and repulsive, there is a curious description of an island where ideas of beauty are topsyturvy; the wrinkles and decrepitude of old age are adored and the loveliness of youth despised - characteristics recalling the Topsyturvy land of European story. In the same tale the costume of the islanders seems borrowed from the san benito. They wore "long robes of cotton on which were painted scveral figures of demons in red, green, and yel- 
low, with flames and other odd conceits." In The History of Malek and the Princess Schirine, Malek, by flying in a magic chest, gains entrance to the apartment of the princess and persuades her and her father that he is the prophet Mahomet and her destined husband. There are touches of humour here, a rare quality in these tales. "I had eat up all my provisions and spent all my money. The prophet Mahomet was reduced to as low a state of want as ever man was that had asked alms." Throughout the tale there is a spirit of mockery, of practical joking, not unlike that of a Spanish story. One cannot help surmising that Le Sage's collaboration with Pétis de la Croix went further than strictly editorial work. In fact, in view of the resemblances to European legend noted above, it is most probable that Pétis de la Croix himself, taking advantage of the wave of enthusiasm recently aroused by Galland's Mille et une Nuit, ${ }^{1}$ treated his oriental manuscripts far more freely even than Galland, added decorative incidents from European sources, and invented the

${ }^{1}$ Les Mille et une Nuit [sic], Contes Arabes traduits en François [sic] par M. Galland. A Paris, 17041717 . 
title Mille et un Jour ${ }^{1}$ in direct imitation of Galland's title.

In general the Persian Tales resembles the Arabian Nights in the mingling of magic and reality, of strange enchantments and oriental customs almost as strange; in dramatic presentation of picturesque incident and background; in lack of characterization and, with few exceptions, of structural unity. But the Persian Tales is far more sentimental, more fantastic, more brilliant in colour. Here the reader is in a fairy-land of charming or grotesque surprises, while in the Arabian Nights, despite the misty clouds of enchantment, there is substantial ground under foot. May not this be one reason why the Arabian Nights has always been a greater favourite in England than the Persian Tales; and why, in France, the popularity of the Persian Tales has equaled, if not surpassed, that of the Arabian Nights?

The Turkish Tales, the third important collection, was translated from French into English in 1708, and appeared also in a version ealled

${ }^{1}$ Les Mille et un Jour [sic] Contes Persans traduits en François [sic] par M. Pétis de la Croix. A Paris, 17101712. 
The Persian and the Turkish Tales Compleat [sic] (1714). ${ }^{1}$ It is a version of the old oriental story of Sendebar, best known to English students in the Middle English form, The Seven Sages of Rome. The frame-tale in this version is briefly as follows: Queen Canzade's evil passion for her stepson turns to hatred upon his rejection of her love and her scheme to murder the king. The prince is bound to forty days' silence for fear of a mysterious calamity predicted by his tutor. The latter, meanwhile, to avoid questions retires discreetly into a cave. Canzade persuades the king to decree the prince's death; the forty viziers successively plead for him by stories of wicked women and loyal sons; the queen endeavours to win her way by tales of evil viziers and murderous princes; until finally the tutor is unearthed, the prince justified, and the queen condemned in his stead. The Tales are appropriately called by the Turks "Malice of Women," for the queen's stories reveal her malice and the vizier's tales defend the prince more by attacking women in general, and the queen in particular, than by praising him.

In this satirical spirit the Turkish Tales

${ }^{1}$ Cf. App. B, I., Nos. 7 and 15 (b), pp. 270 and 273. 
affords a marked contrast to the Persian Tales. The two collections are similar in use of magic and of oriental customs, lack of structural unity, absence of characterization, and emphasis on the story for the story's sake. The Turkish Tales differs in that it contains no elaborate descriptions. This absence of stage-setting, as it were, focuses attention on the plot and throws the characters into bolder relief. A few of the tales, as a result, are admirable narratives. The best is the most famous of the collection, The Santon Barsisa, quoted by Steele in the Guardian, No. 148, and in that form suggesting to Lewis - according to his own statement - the idea of The Monk. ${ }^{1}$ The story here is brief and crude, but swift in movement and powerful in a way not unlike early versions of the Faust saga. The dialogues between the devil and the saint are thoroughly dramatic; no mention has been

${ }^{2}$ Cf. Archiv für das Studium der neueren Sprachen und Literaturen, Vol. CXI. (n. S., XI.), pp. 106-121, "Studien zu M. G. Lewis's Roman 'Ambrosio, or the Monk,", by Otto Ritter; pp. 316-323, “Die eigentliche Quelle von Lewis's 'Monk,", by Georg Herzfeld; Vol. CXIII., pp. 56-65, "Die angebliche Quelle von M. G. Lewis's 'Monk," by Otto Ritter; Vol. CXIV., p. 167, under Kleine Mittcilungen, “ $\mathrm{Zu}$ Archiv CXIII., 63 (Lewis's (Monk')," by Otto Ritter. 
made of the devil at all, and the reader is as utterly unprepared for his sudden stage-entrance as is the saint himself. An evil idea arises in the santon's mind and, quick as thought, "the devil, taking this opportunity, whispered in his ear thus: 'O santon, do not let slip such a fortunate minute.'" The santon yields, commits one crime after another, is detected, and condemned to be hanged. On the scaffold he hears a whisper in his ear: " $\mathrm{O}$ santon, if you will worship me, I will extricate you out of this difficulty and transport you two thousand leagues from here, into a country where you shall be reverenced by men as much as you were before this adventure.' - 'I am content,' says Barsisa; 'deliver me and I will worship thee.' 'Give me first a sign of adoration,' replies the devil; whereupon the santon bowed his head and said, 'I give myself to you.' The devil, then raising his voice, said, 'O Barsisa, I am satisfied; I have obtained what I desired'; and with these words, spitting in his face, he disappeared, and the wretched santon was hanged."

Of the other tales, six deserve mention. Two were quoted in the Spectator: Chec Chehabeddin and the Sultan of Egypt in No. 94; The Fable 
of the Sultan Mahmoud and the Two Owls in No. 512. The third, the story of the King of $\mathrm{Aad},{ }^{1}$ has an interesting resemblance to an incident in Gulliver's Travels. The fourth and fifth are characteristic of the collection, The History of the Brahman and the Young Fiquay, a Turkish version of the Aladdin story, and the oriental apologue of King Togrul-Bey. The sixth, The History of the Prince of Carizme and the Princess of Georgia, may be noted as exceptionally fantastic, and as containing the song attributed to John Hughes:-

"Eternal are:the chains which here The generous souls of lovers bind," etc.

After the Arabian Nights, the Persian Tales, and the Turkish Tales, the best imaginative oriental tales are the English versions of the socalled pseudo-translations. The first to appear in English was The Travels and Adventures of the Three Princes of Serendip ${ }^{3}$... (1722) from the

${ }^{1}$ Cf. App. A, pp. 259-262.

2 The Persian words also are given in the 1708 edition (App. B, I., No. 7, p. 270).

${ }^{3}$ Cf. App. B, I., No. 20, p. 274. Cf. Horace Walpole's coinage of the word "serendipity," meaning "accidental sagacity"; Letters of Horace Walpole, edited by Mrs. 
French of De Mailli [or Mailly], whose version was in turn from the Italian Peregrinaggio . . by Armeno (1557). ${ }^{1} \quad$ The events of the story, in De Mailli's rendering, are said to have occurred "in the happy time when kings were philosophers and sent each other important problems to solve," - a sentiment lacking in the Italian, and characteristic of a French eighteenth-century version. The frame-tale recounts the travels of three "equally beautiful and gifted" princes, who seek culture and win success in various enterprises. In the Emperor Behram's country, their first adventure is the one probably imitated by Voltaire in Zadig. They tell a camel-driver that his lost camel is blind, lame, and laden with honey, butter, etc., but that they have not seen him. When accused of theft, they inform the judge that their close observation of the camel's footprints, the cropped herbage, etc., has led them to infer the truth. Another achievement is their recovery of the Emperor's lost mirror of justice, which has the extraordinary property of detecting falseaccusations. If a slanderer

Paget Toynbee in sixteen volumes. Oxford MCMIII., Vol. III., pp. 203, 204; Letter No. 382, to Horace Mann, January 28,1754 .

${ }^{1}$ Cf. App. B, II., No. 3, p. 295. 
look into the mirror, his face turns black and can be restored only by public confession and penance. Many of the stories are apparently based on Italian novelle of shepherdesses, Venetian ladies, clever goldsmiths, and other similar characters, and are unoriental. There is one story of metempsychosis, however, similar to the oriental tale, Fadlallah and Zemroude, in the Persian Tales. But "the general plan of the Peregrinaggio is more inflexible and homogeneous than is usual in oriental tales." 1 The English version stands by itself in being perhaps the only pseudo-translation which came by way of eighteenth-century France from sixteenthcentury Italy.

One of the most facile and prolific of French writers of pseudo-translations was Thomas Simon Gueullette (1683-1766). Four of his collections were translated into English under the names: Chinese Tales, or the Wonderful Adventures of the Mandarin Fum-Hoam ... (1725); Mogul Tales, or the Dreams of Men Awake: being Stories Told to Divert the Sultanas

${ }^{1}$ Die Reise der Söhne Giaffers aus dem Italienischen des Christoforo Armeno übersetzt durch Johann Wetzel, 1583, herausgegeben v. H. Fischer und J. Bolte, Tübingen, 1895, p. 178. 
of Guzarat, for the Supposed Death of the Sultan (1736); Tartarian Tales; or, a Thousand and One Quarters of Hours (1759); and Peruvian Tales Related in One Thousand and One Hours by One of the Select Virgins of Cuzco, to the Inca of Peru ... (1764, Fourth (?) Edition). ${ }^{1}$ The last named is a worthless collection, oriental or rather pseudo-oriental in everything except locale and interesting only as an example of the ultrafantastic, degenerate oriental tale. One bit of unconscious humour rewards the reader; the author gives local colour to the terrors of Peru by mentioning "muskettas, reptiles, and other insects."

Of the three other collections, the Chinese Tales may serve as the type. The frame-tale is as follows: The sultan of China in disguise wins the love of the princess Gulchenraz, kills the usurper of her kingdom, tests her love by the suit of a mock-sultan, and is accepted by her on condition that her Mahometan faith be unmolested. She agrees to listen to the Mandarin Fum-Hoam, who tells her tales to convert her to belief in transmigration; and the sultan promises that, if she remain unconverted, he will

${ }^{2}$ Cf. App. B, I., No. 22, p. 275. 
become a Mahometan. Fum-Hoam tells many tales, and at the end reveals himself as her lost brother, who is wise as Solomon, and who has brought to pass all the events of the story. He then transports them to his kingdom, Georgia, and admits that there is no truth in the transmigration theory, and that he has told his tales solely to make the sultan keep his promise of embracing Mahometanism. The frame-tale closes with the implication that they all lived happily ever after. The oriental colouring is very slight. Transmigration is mentioned only to be ridiculed. Reference is made to the suttee, to pilgrimages to Mecca, and to the fast of Ramadan according to the Koran. Descriptions of emotion are absurd; one hero dies of grief, with lamentations "like the roarings of a lion." The narratives are often grotesque, e.g. the journey to the Country of Souls, ${ }^{1}$ where the soul can be put into a bag to be brought back to the land of the living and reembodied by placing the bag at the mouth of the corpse. The author's fancy runs riot as to the successive transmigrations of Fum-Hoam, who assumes in tedious

${ }^{1}$ Cf. Orlando Furioso, Canto XXXIV., Astolfo's journey to the moon, where wits are kept. 
succession numerous forms, such as those of a dog, a maid, a flea, and a bat. There is surprisingly little satire, considering the opportunities for observing mankind possible to the ubiquitous Fum-Hoam. In the use of magic, the Chinese Tales follows conventional lines - the elixir of life or water of youth, the secret of transmuting metals to gold, the mysterious words of Solomon which command the genii; cabalistic prayers, which reveal black marble staircases leading to subterranean treasure-caves; and incantations in the manner of Theocritus. Many other incidents imply a knowledge of European legend and literature. One story tells of Grecian shepherds; another of Kolao, the wild man, and his Robinson Crusoe life; another recalls Pandora; another, the fairy tale of brothers rewarded for helping fairies in the form of animals. One incident might easily be a masque of Neptune a venerable man rising from the sea in a chariot of mother-of-pearl, drawn by sea-horses, and accompanied by mermaids. The adventure of the prince in the haunted tower of the forty virgins serves as sequel to a story similar to the Pied Piper of Hamelin. A dwarf agreed for a certain sum to free the city of Ispahan from rats 
by playing on tabor and pipe. When the people refused payment, they were threatened with dire punishments by the dwarf's mother, "a genie in the shape of an old black woman above fifty feet high . . . with a whip in her hand," unless they brought at once forty of their most beautiful daughters. To the sound of the genie's leather trumpet, "these unhappy victims of their father's perfidy" were led to the tower and seen no more until rescued by the prince. The Chinese Tales contains less moralizing than the other pseudo-translations. There is one reference to the happiness of a tranquil life away from court, from lawsuits, and from women; one moral drawn as to the ill results of educating women: "I am, from my own experience, fully satisfied that the care to govern her family should be the only employ of a virtuous wife; and that it is next to a miracle, if pride, or some other more dangerous passion, make not a woman neglect her duty, when she once comes to apply herself to the study of learning, and affects to surpass the rest of her sex." We find, also, the poetical fancy common in Persian literature that even the palace of the king is but an inn, for its successive inhabitants are but travelers upon 
earth toward the same common end, - death; ${ }^{1}$ and the equally familiar figure in which life is compared to a game of chess. "Some act the kings, the queens, the knights, the fools, and simple pawns. There is a vast difference between them, while they are in motion; but when once the game is over, and the chess-board shut, they are all thrown promiscuously together into the same box, without any sort of distinction all then become equal; and there is nothing but our good works and charity towards our neighbours, that will give us the superiority."

Gueullette's two other collections, the Mogul Tales, and the Tartarian Tales, are similar in plan and treatment. Extravagant in the use of magic, fantastic in description and incident, employing European legends freely and oriental colouring very slightly, sometimes moralizing, sometimes coarse, seldom satirical, imitating the faults rather than the excellences of genuine oriental translations, these narratives are frequently entertaining, but possess little intrinsic value.

One special point of interest in the Mogul Tales must not be omitted, - the incident of the ${ }^{1}$ Cf. Spectator, No. 289. 
sinners with flaming hearts, - since this was probably the source of the parallel passage in Beckford's Vathek. It is worth remark as external evidence that the Mogul Tales is in the catalogue of Beckford's library. The points of similarity and the superiority of Vathek are obvious, if the quotations from Vathek, pp. 6265 of this chapter, are compared with the following extract from the Mogul Tales (Weber's Tales of the East, Edinburgh, 1812, Vol. III., p. 58 et seq.). Aboul-Assam tells how he saw "a flambeau . . . carried by a little man ... entering a subterranean passage. ... We went down together.... into the mountain; at last we traversed a long alley of black marble; but so finely polished, that it had the appearance of a looking-glass; . . . we reached a large hall, where we found three men standing mute, and in postures of sorrow. They were looking earnestly on a triangular table, whereon lay a book, with clasps of gold; on its back was this inscription: 'Let no man touch this divine treatise that is not perfectly pure' ... I wish, said I . . that this peace may continue always among you. Peace is banished from these sad places, replied the eldest of the three, with an 
air of sternness. . . . We wait, said the second, in this sepulcher, for the just judgment of God. - You are then, continued I, great sinners. Alas! cried the third, we are continually tortured for our evil actions . . . they unbuttoned their waistcoats, and through their skin, which appeared like crystal, I saw their hearts compassed with fire, by which, though burnt without ceasing, yet [they were] ... never consumed; I then was at no loss for the reason of their looking so ghastly and affrighted." AboulAssam is then shown paintings representing their crimes, rebukes them in horror, is in turn rebuked by a picture of his own past sins, and condemned to blindness for seven years. Vathek is also punished, but the genius of Beckford chooses a more dramatic and awful penalty.

In connection with Vathek, the Adventures of Abdalla, Son of Hanif . . . by Jean Paul Bignon, translated into English by William Hatchett (1729), ${ }^{1}$ is of even greater interest than the Mogul Tales. It is similar in general character to its predecessors. The frame-tale, which recounts Abdalla's search for the fountain of youth, includes all his adventures and the past ${ }^{1}$ Cf. App. B, I., No. 23, pp. 275, 276. 
history of all the people he meets, and is so bewilderingly entangled that the Arabian Nights, by contrast, seems simplicity itself. The tales are more or less interesting stories ${ }^{1}$ of adventure and love, and are melodramatic, humorous, moralizing, and satirical. Magic abounds, European legends and previous oriental tales are freely utilized, and great stress is laid upon the "horrid," the grotesque, the fantastic. Given these characteristics, it is easy to see how Abdalla appealed to the author of Vathek. That it did make a strong appeal is shown by Beckford's numerous borrowings. In every instance he improved upon his original. The author of Abdalla describes rest in a delightful countryplace surrounded by "flowers of remarkable beauty," " birds of every colour," and "very fine trees." Beckford's similar description gives con-

${ }^{1}$ One incident recalls Dr. Edward Everett Hale's entertaining story, My Double and How He Undid Me: A good fairy created for King Giamschid a double, "a phantom, who ate with a very good appetite and who pronounced at intervals, in the tone and voice of the true Giamschid, a few sentences very much to the purpose." (H. Weber's Tales of the East, 1812, Vol. III., p. 671.) The similarity is a mere coincidence. Dr. Hale informs me that he was unacquainted with this story when he wrote $M y$ Double. 
crete images - fountains, roses, jessamines, violets, nightingales, doves, orange trees, palms, and pomegranates. Dilsenguin, the hero in Abdalla, "precipitated himself into a subterranean apartment," seeking "detestable volumes" of magic. The phantoms seized Dilsenguin by the feet and threw him into the well, head foremost. When he reached the hall of Eblis, he found it an immense temple of black and white marble. At the keystone of one of the arches he saw "a globe of fire, which, sometimes obscure and sometimes brilliant, filled the temple with unsteady flashes of light." The globe opened and there descended from it a huge old man in a yellow robe, holding a scepter of gold. He "seated himself upon the throne. It was the formidable Eblis. ... His looks were horrid, his beard and hair bristled. . . . [He had] a hole in the place of a nose," etc. When Dilsenguin thanked him for his magic books, Eblis, "enraged that a mortal should break silence in his temple," kicked him so violently that he lost consciousness. Contrast the impressive description of Vathek's reception by "the formidable Eblis" enthroned upon the globe of fire. "His person was that of a young man, 
whose noble and regular features seemed to have been tarnished by malignant vapours; in his large eyes appeared both pride and despair; his flowing hair retained some resemblance to that of an angel of light; in his hand, which thunder had blasted, he swayed the iron scepter that causes the monster Ouranabad, the Afrits, and all the powers of the abyss to tremble; at his presence the heart of the Caliph sunk within him, and for the first time, he fell prostrate on his face." Beckford's Eblis is a faint but not wholly unworthy echo of Milton's Satan, while Bignon's Eblis is merely the grotesque ogre of the fairy tale.

The last pseudo-translation that need be noticed is the New Arabian Nights (1792), from the French of Dom Chavis and M. Cazotte. ${ }^{1}$ The book purported to be a continuation of the Arabian Nights, translated from the Arabic. Modern scholars believe that the "translators" undoubtedly utilized Arabic manuscripts as a basis, but made so many changes that the book is to be regarded as a pseudo-translation. It may be dismissed as a weak imitation of the Arabian Nights, redeemed in part by two ad${ }^{1}$ Cf. App. B, I., No. 81, p. 290. 
mirable tales: The Robber Caliph and The History of Maugraby ${ }^{1}$ the Magician. The latter has additional interest in that it suggested to Southey the germinal idea of Thalaba. ${ }^{2}$ Maugraby, the evil enchanter, half human, half genie, carries away children to his magical domains under Mt. Atlas, and by tortures and caresses enslaves them for his master Zatanai [Satan]. If obedient, they are taken to the caverns under the sea adjoining the Dom Daniel near Tunis, - the school of magic and the magnificent court of Asmodeus, - where evil magicians assemble in the wane of the moon. The hero of this tale is the captive prince Habed, who after exciting adventures compasses the destruction of Maugraby and the liberation of his prisoners, including the princess of Egypt. The story closes with the marriage of the prince

1 The writer of a recent review, in the New York Evening Post, of Vol. IV., Lane's Arabian Nights, Bohn edition, just issued, interprets the "African" magician of Aladdin as the "Tunisian" magician, and continues: "That Tunis was especially famous for magic does not seem to be elsewhere recorded. Such was, and is, the reputation rather of Morocco and of Africa farther west in general, and in this same tale the magician is also called a Maghribi, strictly a Moroccan."

${ }^{2}$ Cf. App. A, p. 263. 
and the princess. The narrative is marred by coarse incidents and a few long digressions, but contains several interesting passages, e.g. the introductory scenes between Maugraby, the vizier, the buffoon, ${ }^{1}$ and the king; the descriptions of the wiles of the magician; and the account of Habed's life in the fairy palace. The interest is always centered on the hero's terrible task of fighting the powers of darkness, led by Maugraby. The latter possesses no countenance peculiar to himself, but changes even his features according to the passion of the moment and transfers his evil soul from one body to another. "He takes every method to engage the kings of the earth to part with their first-born sons to him that they may become powerful instruments in his hands; ... he prowls about the houses of those that are discontented. If a father . . . be displeased with his son and happen to curse him, he seizes the child; if, on the other hand, the son should curse his father, still the child is made his prey. . . . If a caravan set out for Upper Egypt ... through the desart [sic], the magician mounts on the wind schirak . . . in order to destroy them. When

' Cf. opening scenes of Vathek. 
the unfortunate company are reduced to the last extremity, he appears ... as a benefactor . . on condition that they shall surrender themselves soul and body to him, to Zatanai [Satan] and the great Kokopilesobe [Lucifer]. The caravan agreeing, presently arrives at his retreat, and, instead of two or three hundred beasts of burden, there are now above four hundred; for all the merchants and other persons are metamorphosed into brutes. ... Though he was handsome in his youth, his person is now become a mass of deformity, as well as his mind. His decrepitude is such as may be expected from his great age, which exceeds a century and a half. His human body is a mere chimera; he can, however, assume every form he chooses, and nothing discovers him but the sinister expression of his eye." 1

The other tale, The Robber Caliph, is farcical and amusing - very different from Maugraby. Haroun Alraschid, tired of elaborate court festivals, escapes to his beloved streets of Bagdad in the disguise of an Arab robber-chief, "Il Bondocani." His thirst for adventure is gratified by the rescue of a white-handed beggar-woman,

${ }^{1}$ Weber, op. cit., Vol. II., p. 290. 
who proves to be the princess of Persia. She, likewise, wanders disguised through the city, and unwittingly rouses Haroun's jealousy of a young officer, Yemalledin. The latter and the princess are imprisoned. Again the disguised caliph goes forth, finds a poor old woman with a marvelously beautiful daughter, Zutulbe, and sends the mother to order the cadi to marry Zutulbe and "Il Bondocani." The old woman's mystification, the cadi's haughty behaviour and his sudden obsequiousness at the name of "Il Bondocani" are amusing; and so are the sudden preparations for the gorgeous wedding-feast and the more sudden dispersal of clamouring neighbours by the display of "Il Bondocani's" ring. The caliph discovers from the old woman's talk the innocence of her son Yemalledin, reveals his identity, restores Yemalledin to honour, and gives him the Princess of Persia. Of course all live happily ever after. The dramatic effect throughout is capital, for the reader is in the secret and enjoys with Haroun the complication and the resolution of the plot. There are many admirable touches in dialogue, description, and oriental setting. On the whole, the story deserves to rank with the true Arabian Nights. 
Following these pseudo-translations, three small groups of imaginative oriental fiction deserve brief notice: the heroic romances, the realistic tales, and the eclogues. Of little intrinsic value, they are interesting chiefly as evidence of the diffusion of the orientalizing tendency. The first group includes reprints and imitations of a few of the heroic romances of the previous century. The Beautiful Turk (1720) is another translation of the French romance by G. de Brémond translated as Hattige, or the Amours of the King of Tamaran ..., a Novel (a roman à clef concerning Charles II. and the Duchess of Cleveland), published Amsterdam, 1680, and also in Vol. I. (1679 or 1683 ?), of R. Bentley's Modern Novels, London (1679-1692). ${ }^{1}$ The Bajazet of J. Regnauld de Segrais was reprinted in 1725. ${ }^{2}$ Mrs. Aubin's Noble Slaves, or the Lives and Adventures of Two Lords and Two Ladies (1722 ? $^{3}$ is Spanish in plot and character, but contains minor personages, - Chinese, Persian, etc., - who recount their experiences. In 1733 appeared a translation from the French
${ }^{1}$ Cf. App. B, I., No. 17, p. 274.
${ }^{2}$ Cf. App. B, I., No. 21, pp. 274, 275.
${ }^{8}$ Cf. App. B, I., No. 19, p. 274. 
of D'Orville: The Adventures of Prince Jakaya, or the Triumph of Love over Ambition, being Secret Memoirs of the Ottoman Court, ${ }^{1}$ a romantic tale. Jakaya, the true heir to the Ottoman sultanate, flees in disguise from his brother's murderous wrath, has many adventures, marries for love, and renounces ambition. The story is imaginative, but is too frequently moralistic and didactic. Yet, with others of the same type, it is interesting as constituting the last feeble wave of the receding tide of seventeenth-century heroic romances. It is true that these romances were read far into the eighteenth century; witness Mrs. Lennox's satire, The Female Quixote, and George Colman's Polly Honeycomb. But by 1740 imitations had ceased to be written; the wave had spent its force and ebbed away in stories like The Adventures of Prince Jakaya.

The sccond group referred to at the beginning of the preceding paragraph, also of little intrinsic value, is of even greater consequence as a touchstone of the times. The realistic oriental tales connect the orientalizing tendency, if one may so call it, with the more profound and widespread ${ }^{1}$ Cf. App. B, I., No. 27, p. 277. 
tendency of the age toward realism. Appropriately enough, the first great writer of realistic fiction in the century, was also the first to utilize - though very slightly - the oriental material in a realistic tale. In The Farther $A d$ ventures of Robinson Crusoe (1719), ${ }^{1}$ the hero travels through China, where he meets mandarins, sees porcelain houses, and witnesses "incredible performances." In Muscovy he destroys a village idol, escapes in safety, fights Cossacks, etc. - incidents in the manner of travelers' accounts. In 1755 a feeble imitation of Robinson Crusoe appeared, with some resemblance to an oriental tale. It is best described by the title: The Life and surprizing Adventures of Friga Reveep, of Morlaix, France, who was Sixteen years in an uninhabited Part of Africa and how he met with a young Virgin who was bannish'd and in what manner they liv'd together and had two children, $a$ Son and a Daughter, the latter dying when she was six years of Age; together with their surprizing Deliverance to their own Country again with a faithful Relation of all that past during the Time that he was there. Written in French by himself and translated into ${ }^{1}$ Cr. App. B, I., No. 5 (b), p. 270. 
English by Mr. Transmarine (1755). ${ }^{1}$ Four or five other members of this realistic group, though comparatively unimportant, are worth notice, because they are possibly founded on tales brought home from the East by English merchants, and thus bear witness to the growing interest of England in the Orient. In The History of Rodomond and the Beautiful Indian, an English merchant, saved from treacherous natives by an East Indian girl, escapes with her to England and marries her. The History of Henrietta de Bellgrave ${ }^{2}$ is the story of a girl, who, shipwrecked in the East Indies, escapes from pirates, leads a Robinson Crusoe life, and is finally married to a "Banyan." The Disinterested Nabob (1788) ${ }^{3}$ is an anonymous "novel, interspersed with genuine descriptions of India, its Manners and Customs." The scene is laid partly in India, and there is an unsuccessful attempt at local colour. The story is in reality a mediocre imitation of Sir Charles Grandison.

${ }^{1}$ Cf. App. B, I., No. 48 , p. 283 . In the above-mentioned title, the original spelling is preserved.

${ }^{2}$ These two are included in a frame-tale called The Lady's Drawing-room (1744). App. B, I., No. 35, p. 278.

${ }^{3}$ Cf. App. B, I., No. 76, p. 289. 
The Asiatic Princess, by Mrs. Pilkington (1800), ${ }^{1}$ is oriental only in so far as the heroine is the Princess Merjee of Siam and references are made to Eastern treatment of slaves and to the suttee. The princess is intrusted to an English lady and her husband to be educated by travel. Her instructors moralize on the differences between oriental and English ways, and endeavour to guide her by moral tales. Another realistic story, The Female Captive, has far more life. The entire title reads, The Female Captive, a narrative of Facts which happened in Barbary in the Year 1756, written by herself. London, $1769 .{ }^{2}$ It has many evidences of being a true story. The heroine, engaged to an Englishman, sails for home from Minorca under the care of a Mr. Crisp. Captured by Moors, she passes for his sister, and later for his wife, to save herself. After imprisonments and other hardships, she is given an audience by the prince of the country and thoughtlessly repeats unknown words a French boy interpreter asks her to say. They prove to be, "There is no God but God, and Mahomet is his prophet," and she

$$
\begin{aligned}
& { }^{1} \text { Cf. App. B, I., No. 89, (a), p. } 292 . \\
& { }^{2} \text { Cf. App. B, I., No. } 59 \text {, p. } 286 .
\end{aligned}
$$


is told by the prince that her saying them has made her a Moor, subject to death by fire if she prove renegade. ${ }^{1}$ Through Mr. Crisp's aid she escapes to England. There she finds her fiancé unworthy, and is finally married to Mr. Crisp. The narrative is by far the best of the realistic group. There are frequent appeals to Virtue and Fortitude in true eighteenth-century style, but the story is well told. Little direct description of the narrator is given, yet from what she does and suffers and what others do for her, it is easy to picture her as a fair English girl, shy and brave - an attractive heroine.

The Fair Syrian, by Robert Bage (1787), ${ }^{2}$ is a long and tedious novel in letter-form, diversified by the adventures of the English heroine among the Turks, and extolling her devotion to Virtue. The Anaconda, by "Monk" Lewis, in Romantic Tales (1808), ${ }^{3}$ belongs in certain respects to this group, being a realistic story of the adventures of various English people and natives in the East in their struggles with an anaconda. Before leaving these realistic tales, it may be well

${ }^{1}$ Cf. Voltaire's Travels of Scarmentado, p. 210, post.

${ }^{2}$ Cf. App. B, I., No. 75, p. 289.

${ }^{3}$ Cf. App. B, I., No. 93, pp. 292, 293. 
to mention The Unfortunate Princess, by Mrs. Eliza Haywood (1741), ${ }^{1}$ a fantastic tale called by the author "a veracious history," but bearing every mark of invention. Extravagant in describing magic storms and horrible monsters, coarse, didactic. and bombastic, the story is valuable only as exemplifying both the moralizing and the fantastic tendencies under the guise of realism.

The third group referred to above (p. 46) includes the oriental eclogues, of which the chief writers were William Collins, Thomas Chatterton, and John Scott. ${ }^{2}$ The four brief poems by Collins published in 1742 as Persian Eclogues, ${ }^{3}$ and afterward (1757) called Oriental Eclogues, include: I. Selim, or the Shepherd's Moral, which represents the shepherd Selim in "a valley near

${ }^{1}$ Cf. App. B, I., No. 33, p. 278.

${ }^{2}$ Cf. App. B, I., No. 69, p. 288, Chilcot, Harriet: Ormar and Zabria; and No.64(a), p. 287, Irwin, Eyles: Bedukah and Eastern Eclogues.

3 "Written originally for the entertainment of the Ladies of Tauris and now translated,".a phrase omitted from later editions. Cf. Dr. Johnson, Life of Collins (Chalmers, English Poets. London, 1810, Vol. XIII., p. 193): "In his last illness . . . he spoke with disapprobation of his Oriental Eclogues, as not sufficiently expressive of Asiatic manners, and called them his Irish Eclogues." Cf. App. B, I., No. 34, p. 278. 
Bagdat" calling the shepherdesses to practise various virtues; II. Hassan, or the Camel Driver, being Hassan's lament over the dangers of the desert; III. Abra, or the Georgian Sultana, a poem praising the pastoral life of the beautiful shepherdess who married the Sultan and brought him back occasionally to the happy shepherd life for a vacation from the cares of state; and IV. Agib and Secander, or the Fugitives. These eclogues bear to the later and better work of Collins a relation similar to that borne by Tennyson's youthful experiments in versification to the poems of his maturity. Collins's eclogues are not remarkable as poetry, but they are superior to Chatterton's or Scott's, and they possess something of the delicate finish and the pensive note characteristic of the author of The Ode to Evening. Chatterton's African Eclogues ${ }^{1}$ are three in number: I. Narva and Mored (May, 1770), recounting the love of the priest Narva for the beautiful Mored, and their tragic death; II. The Death of Nicou (June, 1770), who avenged his sister and slew himself; and III. Heccar and Gaira (printed 1784; written January, 1770), the vengeance wrought by Gaira for ${ }^{1}$ Cf. App. B, I., No. 61, p. 286. 
the enslaving of his family. These poems are characterized by crude imaginative force and incoherent, almost Ossianic, fervor. John Scott's (1730-1783) Oriental Eclogues (1782) ${ }^{1}$ (I. Zerad, or the Absent Lover, an Arabian Eclogue; II. Serim, or the Artificial Famine, an East-Indian Eclogue; and III. Li-po, or the Good Governor, a Chinese Eclogue) are early examples of the influence of the movement we have called the new scholarly movement. The author refers to the "elegant and judicious essay" of the "learned and ingenious Mr. Jones" [i.e. Sir William Jones]; and, like Moore and Southey, though with less assimilative power, draws copiously from numerous orientalists. Hence Scott's use of oriental material forms an interesting link between the simple Johnsonian manner of orientalizing by a few phrases - a manner exemplified in the eclogues of Collins - and the elaborate orientalization in the verse of Southey and of Moore. ${ }^{2}$

$i$ Cf. App. B, I., No. 67, p. 287.

2 The only other poems that may be classed as imaginative oriental tales - and that only by stretching a point - are The Indian Philosopher, by Isaac Watts, and the fragment of an eclogue called An Indian Ode, by William King. Cf. Chalmers's English Poets. London, 1810, Vol. XIII., p. 63, and Vol. IX., p. 302. 
Two years after the death of Scott, in 1785, appeared one of the most interesting of all the imaginative oriental tales: Charoba, translated from the French, and published by Clara Reeve in The Progress of Romance. ${ }^{1}$ In addition to considerable intrinsic value, Charoba deserves especial notice as the direct source of Landor's poem, Gebir (1798). The story of Charoba is briefly as follows: Gebirus, the fierce and gigantic king of the Gadites, determines to marry Charoba, queen of Egypt, and take possession of her kingdom. His naive motive is the hope of being cured of an illness by the favourable climate of that country. A prelude concerning Charoba gives an account of her father Totis, a cruel despot, who, like Balak, seeks to propitiate God's servant - in this case, Abraham. Totis dies; Charoba, handsome, "ingenious," generous, and wise, is made queen, and receives from Abraham a blessing, which distinctly foreshadows her victory over Gebirus, and enhances the artistic effect: "Great God, give her subtilty to deceive her enemies and to vanquish all those who shall arise to do her harm and to strive with her for her land." On the appearance of ${ }^{1}$ Cf. App. B, I., No. 70, p. 288. 
Gebirus, Charoba's nurse, a great enchantress, persuades him by rich gifts and by Charoba's promise to marry him when his task is done, to build a city with the stones he has brought to dam the Nile. He makes no progress, because the nurse employs demons of the sea to tear down the work each night. At last he learns from a melancholy shepherd that every evening a fair lady rises from the sea, overcomes the shepherd in wrestling, and takes away a sheep; the flock is diminishing, and he is pining for love of her. Gebirus in his stead overcomes the lady and wins as price of her freedom the secret of circumventing the destructive demons and of getting treasure from a magic cave. Thus he finishes his city. Charoba, desperate, by her nurse's advice poisons his army, receives him with royal honours, and kills him with a poisoned robe. ${ }^{1}$ Three years later she dies from a serpent's sting, and is buried in Gebirus's city.

The scene of the death of Gebirus is dramatic. The subtle nurse, throwing over his shoulders the poisoned robe, sprinkled him with magic water, and he fell at Charoba's feet. The attendants raised him up and seated him on a throne.

${ }^{1}$ Cf. Sophocles, Trachinice (Death of Hercules). 
The nurse said to him: "Is the king well tonight ?' - He replied - 'A mischief on your coming hither! - May you be treated by others as you have treated me! - this only grieves me, that a man of strength and valour should be overcome by the subtilty of a woman.' 'Is there anything you would ask of me before you taste of death?' said the queen - 'I would only intreat,' said he, 'that the words I shall utter may be engraven on one of the pillars of this palace which I have built.' Then said Charoba, 'I give thee my promise that it shall be done; and I also will cause to be engraven on another pillar, "This is the fate of such men as would compel queens to marry them, and kingdoms to receive them for their kings." Tell us now thy last words.'

"Then the king said - 'I, Gebirus the Metaphequian, the son of Gevirus, that have caused marbles to be polished, - both the red and the green stone to be wrought curiously; who was possessed of gold, and jewels, and various treasures; who have raised armies; built cities, erected palaces:- who have cut my way through mountains; have stopped rivers; and done many great and wonderful actions:- 
with all this my power and my strength, and my valour and my riches, I have been circumvented by the wiles of a woman; weak, impotent, and deceitful; who hath deprived me of my strength and understanding; and finally hath taken away my life: - wherefore, whoever is desirous to be great and to prosper; (though there is no certainty of long success in this world) - yet, let him put no trust in a woman, but let him, at all times, beware of the craft and subtilty of a woman.' After saying these words, he fainted away and they supposed him dead; but after some time he revived again. Charoba comforted. him and renewed her promise to him. Being at the point of death, he said: 'Oh Charoba! - triumph not in my death! - for there shall come upon thee a day like unto this, and the time is not very far distant. - Then thou shalt reflect on the vicissitudes of fortune and the certainty of death." 1

The other notable scene, the victory of Gebirus over the sea-nymph, recalls the SiegfriedBrunhilde story. The entire shepherd-episode, the nightly destruction of the day's work, and the incident of the poisoned robe, are like classic

${ }^{1}$ Cf. Iliad, XXII (Death of Hector). 
legends. The strange demons of the sea, the spell-bound statues, the enchanted cave, remind one of many oriental tales. Magic in Charoba is used with considerable skill, and is made subsidiary to, and symbolic of, human subtlety. It is the cunning of Charoba's nurse, more than her witchcraft, that wins the final victory, and both kinds of skill typify the desperate resistance of Charoba's will to the determination of Gebirus. But the characterization is faint, as in other oriental tales; the characters are suggested rather than wrought out. As a whole, Charoba has a rude, tragic force far superior to that of the average oriental tale. No wonder it kindled the imagination of Landor.

The poet's use of the material he found in Charoba is characteristic of his peculiar genius. He has kept the main features: the determined wooing of the princess by Gebir, the building and destruction of his city, the shepherd-episode, and the manner of Gebir's death. He has omitted the prelude concerning Totis and Abraham, and the sequel concerning Charoba's death. The poem closes with the death of Gebir, consistently with Landor's theme, which is not The History of Charoba, but Gebir. For the same reason 
throughout the poem he has heightened the character of Gebir into an heroic figure of almost epic proportions. The Gebirus of the History, a fierce and rude giant, who covets Egypt for selfish reasons, gives place to a patriotic hero, who invades Egypt in revenge for ancestral wrongs, ambitious, brave, full of pity for his brother Tamar and of love for Charoba, devout and reverent to the gods, oppressed by impending fate, yet undaunted. It is the figure of the traditional epic hero. To throw it into bolder relief, Landor has changed Charoba from the proud queen to a love-sick girl, whose fear and pride keep her from avowing her passion for Gebir. Her silence causes Gebir's death, for her nurse Dalica, inferring that she does not love him, proceeds, unknown to Charoba, to compass his death. Dalica's use of magic gives Landor the opportunity of inserting one of his most striking passages, describing her visit to the ruined city and incantations over the poisoned robe. The magic in Gebir is no longer the primitive enchantment of The History of Charoba. The latter recalls Biblical and oriental stories, such as the Witch of Endor or the Arabian Nights; but the former is rather the magic of classical legend, - 
incantations like those in Theocritus and Homer. The descent into the subterranean treasurecave in Charoba is replaced by the journey of Gebir to Hades, where he is taught the futility of ambition and the certainty of punishment for evil-doers and of reward for the righteous after death. The shepherd-episode is developed into a story by itself after the manner of Ovid, with descriptions of the nymph, the woods, the seashore, the shepherd, and the wrestling-match. In such ways the poem assumes an entirely different aspect from that of the History. It has lost the crude and primitive simplicity of the conflict between the wills of Charoba and of Gebirus, but it has gained in the heroic proportions of the character of Gebir, in remarkable descriptive passages, and in blank verse of great, though uneven, beauty.

Of even greater significance than Charoba is the History of the Caliph Vathek, ${ }^{1}$ the bizarre masterpiece of William Beckford, which holds among all the oriental tales of the century a unique

${ }^{1}$ In English, 1786; in French, 1787. It had been written between January, 1782, and January, 1783, in French, by Beckford. Cf. App. B, I., No. 73 (a), p. 288; and Vathek, edited by Richard Garnett. London, 1893, Introduction. 
and deservedly high place. It is indeed almost the only modern oriental story "which might appear without disadvantage in the Arabian. Nights, with Aladdin on its right hand and Ali Baba on its left." 1 Although not a great book, it is entitled to live chiefly for the sake of one remarkable scene - the catastrophe in the Hall of Eblis - in which the author, having laid aside the mockery, the coarseness, and the flippancy that reduce the first part of the book to the level of a mere jeu d'esprit, shows himself capable of conceiving and depicting an impressive catastrophe. From the moment when Vathek and Nouronihar approach the dark mountains guarding the infernal regions until they meet their doom, the note of horror is sustained. "A deathlike stillness reigned over the mountain and through the air; the moon dilated on a vast platform the shade of the lofty columns which reached from the terrace almost to the clouds; the gloomy watch-towers were veiled by no roof, and their capitals, of an architecture unknown in the records of the earth, served as an asylum for the birds of darkness, which, alarmed at the approach of such visitants, fled away

${ }^{1}$ Garnett, op. cit., Introduction, p. xxvii. 
croaking." They proceeded, and, "ascending the steps of a vast staircase, reached the terrace, which was flagged with squares of marble, and resembled a smooth expanse of water, upon whose surface not a leaf ever dared to vegetate; on the right rose the watch-towers, ranged before the ruins of an immense palace." On the walls Vathek beheld an Arabic inscription permitting him to enter the subterranean abode of Eblis. "He had scarcely read these words before the mountain against which the terrace was reared, trembled, and the watch-towers were ready to topple headlong upon them; the rock yawned, and disclosed 'within it a staircase of polished marble that seemed to approach the abyss; upon each stair were planted two large torches, like those Nouronihar had seen in her vision, the camphorated vapour ascending from which gathered into a cloud under the hollow of the vault." They descended to be welcomed by the malignant Giaour who had first tempted Vathek, and to be led into a magnificent hall radiant with light and fragrant with subtle odours, but containing "a vast multitude incessantly passing, who severally kept their right hands on their hearts," as if in agony. Refusing to explain 
this ominous mystery, the guide conducted them into the presence of "the formidable Eblis," the fallen archangel enthroned on a globe of fire. ${ }^{1}$ He received them and promised them treasures and talismans. But when they eagerly followed the evil Giaour to an inner treasurechamber, they heard from "the great Soliman" himself an account of his ambitions, his evil deeds, and his terrible punishment. He "raised his hands toward Heaven ... and the Caliph discerned through his bosom, which was transparent as crystal, his heart enveloped in flames." To Vathek's cry of terror the malicious Giaour replied: "Know, miserable prince! thou art now in the abode of vengeance and despair: thy heart also will be kindled, like those of the other votaries of Eblis. A few days are allotted to thee previous to this fatal period; employ them as

${ }^{1}$ Cf. Lady Burton's version of Sir Richard Burton's . Arabian Nights, edited by J. H. McCarthy (London, 1886), n., p. 11, which, following the Koran and the Talmud, calls Iblis (Eblis) a rebellious angel who refused to worship Adam, caused Adam and Eve to lose Paradise, and still betrays mankind.

Cf. E. W. Lane, Arabian Society in the Middle Ages, Studies in the Arabian Nights, edited by S. Lane-Poole, London, 1883, who, on p. 32, says, "Iblecs is represented as saying, "Thou hast created me of fire and hast created him [Adam] of earth.' Kur. VII. and XXXVIII., 77." 
thou wilt; recline on these heaps of gold; command the Infernal Potentates, . . . no barrier shall be shut against thee; as for me, I have fulfilled my mission: I now leave thee to thyself.' At these words he vanished." When the inevitable hour came, their hearts "immediately took fire, and they at once lost the most precious of the gifts of Heaven - Hope." Their mutual passion turned into hate and they "plunged themselves into the accursed multitude, there to wander in an eternity of unabating anguish."

The rest of the book does not begin to equal the catastrophe. Perhaps, indeed, one should not take it too seriously, but regard it rather as an intentionally absurd and brilliant extravaganza. Beckford seems to have begun merely with the idea of writing a clever oriental tale in the lighter manner of Voltaire and Count Hamilton; but, as he went on improvising one fantastic scene after another, the concept of the Hall of Eblis fired his imagination and roused his real genius. The plot follows the caprice of the narrator in turning aside for grotesque episodes, but is clear in its main course. It begins with Vathek's impious building of a marvelously high tower from whence he studies 
astrology. Suddenly "a hidious Giaour" appears at court and intensifies the Caliph's evil ambition for power and riches at any cost. Vathek abjures his Mahometan faith, murders, or at least attempts to murder, fifty innocent children after winning their confidence; with the aid of his mother, a horrible sorceress, kills many of his faithful subjects; insults holy dervishes; and finally violates the sacred hospitality of the Emir Fakreddin by seducing his daughter Nouronihar. Her ambition strengthens that of Vathek, and together they go on to their inevitable fate. Throughout the story premonitions, ominous hints of impending disaster, are skilfully used to prepare for the tragic outcome. Charming scenes of quiet beauty - serene sunsets, children playing with butterflies and flowers, nightingales singing among the roses are almost invariably followed by some sudden horror: an eclipse, streaks of blood across the blue sky, a vast black chasm, and other terrifying portents. The whole book gives the impression of an extraordinary dream. On one occasion Nouronihar, led by a strange globe of fire, followed through the darkness. "She stopped a second time, the sound of waterfalls mingling 
their murmurs, the hollow rustlings amongst the palm-branches, and the funereal screams of the birds from their rifted trunks, all conspired to fill her with terror; she imagined every moment that she trod on some venomous reptile; all the stories of malignant Dives and dismal Goules thronged into her memory; but her curiosity was, notwithstanding, stronger than her fears." Such passages reveal the kinship of Vathek with The Mysteries of Udolpho and other "tales of terror." An interesting distinction is noticeable between the kind of horror present here and that in tales like the Arabian Nights. In the latter it is more objective and lacks the psychological, uncanny quality found in Vathek and the others. Vathek is, however, a thoroughly oriental tale of terror. The author handles his rich store of oriental allusions, names, phrases, and imagery, so easily that one would hardly realize how great the abundance is, if one were not confronted with the elaborate annotations by the first editor, Henley. The exotic brilliance of the various scenes is enhanced by references to the angels Munkir and Nekir, who guard the bridge of death; to incantations and prayers; to the blue butterflies of Cash- 
mere; the loves of Megnoun and Leileh; cheeks the colour of the blossom of the pomegranate, etc. Another element of charm in Vathek is the style, admirably clear and forcible, though occasionally grandiose. Written by Beckford originally in French, the book retains in the English version something of the French manner. Always lucid, sometimes oratorical, frequently crisp and witty, the style recalls that of Count Hamilton and of Voltaire. Beckford follows his French prototypes, also, in his spirit of mockery and sarcasm, his fitful humour, and intentional extravagance. When Vathek was angry "one of his eyes became so terrible, that no person could bear to behold it, and the wretch upon whom it was fixed instantly fell backward and sometimes expired. For fear, however, of depopulating his domains and making his palace desolate, he but rarely gave way to his anger." Vathek "wished to know everything, even sciences that did not exist." In one of the most grotesque scenes the Caliph and all his court were bewitched into kicking the Giaour, who had rolled himself up into a ball, until he disappeared into a chasm.

But Beckford's mockery has frequently a re- 
pulsive quality; it is brutal as well as cynical, and usually dwells with repellent emphasis on things that appeal to the senses. His brief and brilliant descriptions of sensuous beauty colour, form, fragrance, melody - are also too frequently tinged with sensuality. This does not preclude, however, the moralizing tendency; in fact, the two propensities are often coexistent in the oriental tales, as they are in other forms of literature. Besides repulsive mockery and sensuality the most serious defect in Vathek is one we have noticed as distinctive of the oriental fiction under discussion, i.e. lack of characterization. The hero himself is a mere bundle of attributes, self-indulgent, voluptuous, cruel, and ambitious, not a living individual. Hence even the impressive catastrophe lacks vitality and fails to rouse either the tragic terror or the tragic pity.

Vathek has been called a sporadic and isolated phenomenon in eightcenth-century fiction. In one sense that is true; there was before Vathek no book just like it, and there has been none since. Yet it is far more closely connected with its predecessors and successors than has been generally acknowledged. We have already 
pointed out the obligations of Beckford to the Mogul Tales and the Adventures of Abdalla and suggested his indebtedness to Hamilton and Voltaire. The Arabian Nights was an obvious source of inspiration. The moralistic tales of Dr. Johnson and of Hawkesworth, in which the hero is punished for evil deeds, in all probability gave suggestions to Beckford. In the scene of the Hall of Eblis, Vathek is unique, and in a certain brilliance of execution the book has few equals. Yet far from being sporadic or abnormal, it is rather an epitome of many characteristic features of the oriental tale: fantastic in plot and brilliant in colouring like the Arabian Nights; weak in characterization, marred by sensuality, and grotesque in incident like many oriental tales; witty and satirical like some of the fiction of Voltaire and Hamilton; and tinged with the moralizing spirit seen in Dr. Johnson's tales. As a "tale of terror" it exemplifies another contemporary tendency of English fiction. The wealth of oriental allusion drawn from books reflects one more contemporaneous movement, the revival of interest in the East by scholars like Sir William Jones, and in so far foreshadows the similar use of similar material by Moore, Southey, 
and Byron. To Byron, ${ }^{1}$ moreover, as to lesser writers like Barry Cornwall, ${ }^{2}$ Vathek was a direct source of inspiration. ${ }^{3}$ For all these reasons the book is especially interesting to students of the literary history of the times. ${ }^{4}$

Half-way between the imaginative oriental tales and the moralistic is a small group including such stories as Amorassan, or the Spirit of the Frozen Ocean, ${ }^{5}$ and The History of Abdalla and Zoraide, or Filial and Paternal Love. The former is one of the Romantic Tales of M. G. Lewis (1808), and is in part a close translation from Der Faust der Morgenländer by F. M. Klinger and in part original with Lewis. It is a heavy and uninteresting story concerning a caliph, his brother, good and bad viziers, genii, and fishermen. The spirit of the frozen ocean comes to the good vizier Amorassan "to dispel.

${ }^{1}$ Cf. App. A., pp. 258, $259 . \quad{ }^{2}$ Cf. pp. 251, 252, post.

${ }^{3} \mathrm{Cf}$. also the two voices overheard by Nouronihar with The Ancient Mariner and Tennyson, The Two Voices.

${ }^{4}$ Beckford also wrote a short oriental tale, Al Raoui, nominally "translated from the Arabic" but probably composed by Beckford, 1783, and first printed 1799 . It is a fanciful and rather pleasing romantic tale and may be found in Cyrus Redding, Memoirs of William Beckford. London, 1859, Vol. I., pp. 213-226.

Cf. App. B, I., No. 93, pp. 292, 293. 
illusions," and shows him so much of the truth about mankind that he is handicapped in all his actions and exiled. He attains happiness only after dismissing the uncomfortable monitor. The moral is explicit: Do not endeavour to dispel illusions, "let benevolence and reason guide you: beyond that all is Destiny." There is a slight attempt at oriental colouring and at fanciful descriptions, but the tale is of little value. The History of Abdalla and Zoraide ${ }^{1}$ (1750?) is recommended on the title-page as "well worthy the perusal of every tender parent and dutiful child"; and, as might be inferred, is a highly moral effort. It is interesting chiefly in that it is the possible source of a tale used by Goldsmith to embellish The Citizen of the World, and that it may, with Amorassan, be taken as a type of the imaginative oriental tale so far removed from purely imaginative fiction like the Arabian Nights, the Persian Tales, or Charoba, as to be almost moralistic.

1 Based on a story in Lyttelton's Persian Letters. Cf. pp. 180 , n. 1, and 185, post. Goldsmith may have drawn directly from Lyttelton, or from this more recent (1750?) version. Cf. also App. B, I., No. 41, p. 281. 


\section{CHAPTER II}

THE MORALISTIC GROUP

IF among the imaginative tales there are some that approach the moralistic, on the other hand there are among the moralistic tales at least three thoroughly imaginative. Two are translations of contes by Marmontel: The Watermen of Besons and Friendship put to the Test; the third is Thomas Parnell's poem, The Hermit. Marmontel's two tales share the characteristics of his Contes Moraux in general, "light, elegant, and graceful beyond anything to which I can compare them in English: their form is exquisite, and they. are sometimes imagined with a fineness, a poetic subtlety, that is truly delicious. If the reader can fancy the humor of some of the stories in the Spectator turned wit, their grace indefinitely enhanced, their not very keen perception of the delicate and the indelicate indefinitely blunted, their characterization sharpened almost to an edge of cynicism at times, he will have something 
like an image of the Moral Tales in his mind." " In fact, as Mr. Howells suggests in the same essay, "The Moral Tales of Marmontel are moral, as the Exemplary Novels of Cervantes are exemplary; the adjectives are used in an old literary sense, and do not quite promise the spiritual edification of the reader, or if they promise it, do not fulfil the promise . . . they are not such reading as we might now put into young people's hands without fear of offending their modesty, but they must have seemed miracles of purity in their time, and they certainly take the side of virtue, of common sense, and of nature, whenever there is a question of these in the plot." Marmontel himself says that he has endeavoured "de rendre la vertu aimable"; and he adds: "Enfin j'ai tâché partout de peindre ou les mœurs de la societé, ou les sentiments de la nature; et c'est ce qui m'a fait donner à ce Recueil le titre de Contes Moraux." 2

Clearly, then, Marmontel stands half-way between purely imaginative writers and weightier

${ }^{1}$ Marmontel, J. F., Memoirs (Boston, 1878). Introductory essay by W. D. Howells, p. 25.

${ }^{2}$ Preface to Contes Moraux in Euvres, Paris, 1818, Vol. III., p. xiv. 
moralists like Dr. Johnson, who paraphrased Horace:-

\section{"Garrit aniles}

Ex re fabellas."

— Sat., II., VI., 76.

"The cheerful sage, when solemn dictates fail, Conceals the moral counsel in a tale." ${ }_{1}$

The Watermen of Besons ${ }^{2}$ is a story of multifarious adventures. The beautiful and virtuous heroine, a young French girl, is slave successively to a sultan, a prince, an old Cypriote, and a Knight of Malta; preserves both life and honour; and is ultimately reunited to her faithful lover André, the Waterman of Besons. He, meanwhile, has been hither and yon in the Orient, as prisoner, vizier, and cook, escaping from one farcical predicament after another. The scenes change from France to Persia, India, and Syria. The oriental setting is picturesque, if slight, and assists in emphasizing the virtue and piety of the heroine and in exalting the simple country life of the boatman and his family in contrast to the luxury and vain pleasures of the sultan's court. The story is cleverly told from introduction to

${ }^{1}$ Rambler, No. 65.

${ }^{2}$ Cf. App. B, I., No. 54 (c), p. 285. 
close ; and, except for some ostentatious moralizing and a few questionable incidents, is thoroughly attractive. In Friendship put to the Test, ${ }^{1}$ there is more moralizing and less art. It is a commonplace tale of the self-sacrifice of a youth who relinquishes his bride to his friend on discovering their mutual love. The heroine is a young East Indian, daughter to a pious Brahmin who worships Vishnu by the sacred Ganges. The author endeavours to give additional local colour by referring to "the custom of flattering a widow before she is burned." $\mathrm{He}$ satirizes European bigotry by describing the Brahmin's tolerance toward other creeds; makes one of his oriental personages criticize European etiquette in the manner of the Lettres Persanes; and praises simplicity and the ingenuous emotions of nature quite after the fashion of Rousseau. ${ }^{2}$

Marmontel's tales have been praised by no less a critic than Ruskin as being "exquisitely

${ }^{1}$ Cf. App. B, I., No. 54 (b), pp. 284, 285.

${ }^{2}$ Hugh Kelly's The Romance of an Hour, an afterpiece in two acts, was performed first, 1774. Two editions were printed. The plot was borrowed from Marmontel's tale, L'Amitie à l'Epreuve. [Gordon Goodwin in Dictionary of National Biography, article "Hugh Kelly".] 
finished." With them, so far as careful structure and polished style are concerned, The Hermit ${ }^{1}$ of Thomas Parnell may not unreasonably be classed. The poem is so well-known that only a brief comment is necessary here. It is a good example of the beauty and force given to an exceedingly simple narrative by the power of style. The tale was not original with Parnell, but was an inheritance from the earlier stores of oriental fiction given to Europe by the East during the Middle Ages. Pope writes: "The poem is very good." The story was written originally in Spanish [whence probably Howell had translated it into prose, and inserted it in one of his letters]." 2 Gaston Paris mentions the same story, L'ange et l'Ermite among the contes dévots of the Middle Ages, and says it is "juif sans doute d'origine." s Wilhelm Seele ${ }^{4}$ enumerates various versions and

${ }^{1}$ Cf. App. B, I., No. 18, p. 274.

'Spence's Anecdotes, Observations, and Characters of Books and Men, a Selection, edited by John Underhill. London [n. d.], p. 168.

${ }^{3}$ La litterature frangaise au moyen age. Paris, 1905, p. 242.

- Voltaire's Roman Zadig ou la Destinée, Eine Quellen-forschung ... von Wilhelm Seele . . Leipzig, Reudnitz, 1891. Cf. also G. A. Aitken's Introduction to Parnell's Poems, Aldine Edition. London, 1894, and 
mentions that of Parnell as one of the accepted sources of Zadig.

The opening lines of Parnell's poem describing the peaceful life of the hermit are characteristic: -

"Far in a wild, unknown to public view, From youth to age a reverend hermit grew; The moss his bed, the cave his humble cell; His food the fruits, his drink the crystal well: Remote from man, with God he pass'd the days, Prayer all his business, all his pleasure praise."

A doubt of the wisdom and power of Providence impels him to go out into the world to observe the ways of God with men. A beautiful youth becomes his companion and startles him by committing strange crimes culminating in apparently wanton murder. The hermit, in anger, begins to rebuke the youth:-

“'Detested wretch!'- but scarce his speech began, When the strange partner seem'd no longer man:

His youthful face grew more serenely sweet; His robe turn'd white, and flow'd upon his feet; Fair rounds of radiant points invest his hair; Celestial odours breathe through purpled air;

Rev. John Mitford's Life of Parnell (p. 61 n.), prefixed to The Poetical Works of Thomas Parnell. London, 1852. 
And wings, whose colours glitter'd on the Day, Wide at his back their gradual plumes display. The form ethereal bursts upon his sight, And moves in all the majesty of light."

The angel explains each apparent crime as in reality a deed of benevolence; the hermit learns to trust the mysterious ways of Providence and returns in peace to his cell. The poem has been called Parnell's masterpiece; and is, indeed, an admirable example of the conte moral in verse.

We suggested, above, two meanings of the word "moral": one, that of Marmontel, referring chiefly to manners; the other, that of Dr. Johnson, emphasizing conduct. It is the latter meaning that best characterizes the numerous moral oriental tales in eighteenth-century England the tales which we designate as "moralistic."

Even in the hands of Addison and Steele the oriental tale was speedily utilized to inculcate right living and was made into a story "with a purpose," - in a word, became moralistic. The avowed aim of the Spectator and the Tatler was to reconcile wit and morality, to entertain and to preach, to hold the mirror of kindly ridicule up to society, to smile away the follies or vices of the world, and to present serene, tem- 
perate, and beautiful ideals of thought and of conduct. Hence, even the fiction that frequently constitutes a vital part of the essays is permeated with the same spirit. This holds true of the character-sketches of Addison's real and imaginary correspondents and acquaintances, including even Sir Roger himself. It is true, also, of the frequent allegorical visions and dreams, of the numerous classical stories, and of the occasional oriental tales. To these various forms of fiction Addison turned, "rambling," as he says, "into several stories, fetching one to my present purpose." Attracted as the great essayists were by the touch of extravagance, the strange dress and colouring, the unfamiliar nomenclature and oriental fancies in these tales, they felt constrained, nevertheless, to apologize for such unclassical material and to justify their use of it. In the Spectator, No. 512, on the fable as the best form of giving advice, Addison tells the entertaining story of the Sultan Mahmoud and the vizier who pretended to understand birds' conversation, and introduces it by saying: "[There is] a pretty instance of this nature in a Turkish Tale, which I do not like the worse for that little oriental extravagance which is mixed with it." "The vir- 
tue of complaisance in friendly intercourse" is "very prettily illustrated by a little wild Arabian tale," the story of Shacabac and the Barmecide's Feast. ${ }^{1}$

The story of the Santon Barsisa ${ }^{2}$ is praised by Steele for suggesting serious reflections and an obvious Christian moral. Alnaschar from the Arabian Nights is used to conclude an essay upon the transitoriness of human life and the vain hope of worldly ambitions. Addison says, "What I have here said may serve as a moral to an Arabian fable which I find translated into French by Monsieur Galland [and which is marked by] a wild but natural simplicity." 3 In the story of the Persian Emperor's Riddle," the question, "What is the tree that has three hundred and sixty-five leaves, black and white?" is one of the riddles in the story of the Princess of China (Persian Tales). The same answer is given, "A year," but Addison affixes the reflection that the leaves represent the king's acts, which look white to his friends and black to his enemies. The "Persian story" of the just sul-

1 Guardian, No. 162.

${ }^{3}$ Spectator, No. 535.

${ }^{2}$ Ibid., No. 148, cf. pp. 27, 28, ante. 'Freeholder, No. 17. 
tan, who executed a culprit in the dark, though he knew that it might be his son, concludes an essay on justice. ${ }^{1}$ The riddle-like acts of the sultan and his final explanation seem characteristically oriental.

Two tales are apparently original with Addison: the Story of Helim and Abdallah ${ }^{2}$ and the Story of Hilpa, Harpath, and Shalum. ${ }^{3}$ The former Addison says he found "lately translated out of an Arabian manuscript." It has, he thinks, "very much the turn of an oriental tale; ... never before printed; . . . [and doubtless will be] highly acceptable to the reader." From such an introduction the reader naturally infers that Addison invented the tale. The character of the story confirms this inference. Helim, the great physician, educates Ibrahim and Abdallah, sons to the tyrant Alnareschin, who has killed thirty-five wives and twenty sons. Abdallah and Balsora, the daughter of Helim, fall in love; the king covets Balsora; Helim gives her a sleeping potion; and she wakes in a tomb with $\mathrm{Ab}$ dallah." They escape past the guards in the

${ }^{1}$ Guardian, No.99. Cf. The Persian Moonshee, Pt. II., Story 5, translated by Francis Gladwin, Calcutta and London, 1801, p. 3.

${ }^{2}$ Guardian, No. 167.

3 Spectator, Nos. 584, 585.

${ }^{4} \mathrm{Cf}$. Romeo and Juliet. 
guise of spirits and live happily in a beautiful retreat on a mountain. After the tyrant's death Helim reunites Ibrahim and Abdallah, and ultimately Abdallah's son succeeds Ibrahim. For oriental colouring Addison refers to the seal of Solomon, Persia, Mahomet, etc. His characters are the commonplace types: the tyrant, the wise physician, the beautiful girl, and others. He employs fanciful touches in describing the black marble palace with its hundred ebony doors guarded by negroes and its five thousand lamps; and also in recounting the lovers' escape by moonlight as spirits in white and azure silk robes. No direct moral is drawn, but virtue is rewarded and vice thwarted. The other moral oriental tale by Addison is called by him "an antediluvian novel," the Story of Hilpa, Harpath, and Shalum. 'He pretends to have found it in Chinese records, "the only antediluvian billet-doux in existence," and attempts to give verisimilitude by localizing it in places with fictitious names that have an oriental sound, and by using flowery language. A humorous effect of mock antiquity is obtained by exaggerating the age of the characters,

${ }^{1}$ Spectator, No. 583. 
- Hilpa, for instance, is a beautiful girl of seventy, - and a touch of satire, by implying that only an antediluvian woman would marry for money. The feeble characterization - if characterization it can be called - of the haughty and contemptuous Harpath and the good and gentle Shalum forecasts the later efforts of Johnson and Hawkesworth. Although the tale contains no explicit moral, it is used to illustrate a "kind of moral virtue" - the planting of trees. Antediluvians had an advantage over us in that they outlived the trees they planted. The lack of direct moralizing in these two original tales is unusual: at least half the oriental tales quoted or adapted in the Addisonian periodicals enunciate an express moral lesson. The morality, like the philosophy, is not distinctly oriental in character. Industry and economy, health and cleanliness, prudence and justice, kindly "complaisance," the art of giving advice and seeking instruction, serenity in the face of calumny and death, - it is the Addisonian code of virtues in oriental guise.

In thus utilizing the oriental tale for moralistic purposes and - as we shall see later ${ }^{1}-$ for ${ }^{1}$ Chap. III. 
philosophic ends also, Addison gave the prelude and the direction to two distinct tendencies of the entire period. ${ }^{1}$ The strength of the moralizing proclivity may be illustrated from the translation of the imaginative Mogul Tales of Gueullette. On the title-page of the edition of 1736 , the anonymous English translator quotes:-

"In pleasing Tales, the artful Sage can give Rules, how in Happiness and Ease to live:

Can shew what Good should most attract the Mind, And how our Woes we from our Vices find; Delighting, yet instructing thus our Youth, Who catch at Fable - How to gather Truth."

He then gives a prefatory "Discourse on the Usefulness of Romances," 2 in the course of which he says that romances are useful in that they "Engage Young People to love Reading," instil in them "Address, Politeness, and a high sense of Virtue," and teach them the geography and customs of foreign countries. "Clownish People, and Persons long doom'd to what is

${ }^{1}$ In the satirical group Marana and Brown precede Addison. The great essayist assisted in directing the tendeney, and was the first notable English writer to popularize it. Cf. Chap. IV.

${ }^{2}$ Dedicated to Raphael Courtevile, Esq. In the passage quoted the author's spelling is preserved. 
called Low-Life . . . ought on their coming into the World to be treated as Children and these Books recommended to them. By them they are led at once into Courts and into Camps, are taught the Language of the Toilette and the Drawing-Room, and are made acquainted with those superior Sentiments which inhabit only great Souls, and distinguish true Heroes from the Vulgar. By turning over such Volumes, Rusticity is quickly polished, and the Beauties of a gentile Behaviour set in such a light, as must attract a Heart not entirely Savage. . . . The late Humour of reading Oriental Romances, such as the Arabian, Persian, and Turkish Tales, though I will not contend, it has much better'd our Morals, has, however, extended our Notions, and made the Customs of the East much more familiar to us than they were before, or probably ever would have been, had they not been communicated to us by this indirect, and pleasant Way. Now these are certainly very great Advantages, and very viuluable Acquirements, even to Men; and many giddy young Fellows have been, by amusing themselves with such Trifles, taught to conceive clearly, and to converse properly, in relation to Things which 
otherwise they would have known nothing about." The writer then proceeds to bring out the moral which, in his opinion, is latent in oriental tales, especially in this collection. "The grand Moral of these ingenious Tales is contained in this Sentence: True Virtue alone is capable of standing all Trials, and persisting therein is the only means of attaining solid Happiness. The Author has illustrated the Truth of this Maxim by a Multitude of Instances, all of them probable, and some of them I have Reason to think founded upon matters of Fact. Human' Nature is represented . . . with strict regard to Truth, and in a manner which cannot fail of improving, as well as entertaining, the considerate Reader. From the perusal of these Sheets, he will have it in his Power to make a hundred Reflections, which may produce very happy Effects, if apply'd to the Regulation of his own Conduct. He will, for Example, see how ridiculous it is for a Man in Years to hope for Satisfaction from "engaging in new Amours, and vainly flattering himself that Fondness and grey Hairs will ever attach the Soul of a sprightly young Woman.... The Misfortunes of the Blind Man of Chitor, cannot fail of putting him 
who reads them, in Mind of the Danger there is in making an ill Use of Court Favour, and of studying nothing but the gratification of sensual Appetites; what is supernatural in that Story, is certainly wrought with great Strength of Genius, and gives us a fine Idea of the Wisdom and Justice of Providence, in punishing the Offenses of Mankind," and so on to the end. Similar sentiments, though less explicit, are found in Gueullette's own dedication of the Tartarian Tales to the Duke of Chartres. "The Book ... is of the Nature of those which are improving as well as entertaining. Though the Subject appear light, yet it conduces to something useful on Account of the Morality couched in it." 1

In addition to giving a general moralistic direction to the uses of oriental or pseudo-oriental material, Addison initiated the method employed in writing moral oriental tales. The similarities between the two oriental tales written by Dr. Johnson for the Rambler, and Addison's original stories in the Spectator, are obvious and afford another instance of Johnson's well-known emulation of the earlier essayist. In each case

${ }^{1}$ Quoted in the translation of $\mathbf{1 7 5 9 .}$ 
the result was insignificant in literary value. ${ }^{1}$ Yet the attitude Addison took toward this oriental material and the use he made of it are exceedingly interesting to the student of the period, even though the actual tales he composed are so few and so trifling. The same is true of Dr. Johnson, and although his "clumsy gambols," ${ }^{2}$ and those of his contemporary imitator, Dr. John Hawkesworth, need not detain us long, they must not be overlooked.

Addison's touch is lighter, as might be expected, while Johnson's manner is certainly clumsy; but in childish simplicity of plan, of characterization, and of oriental colouring, such a tale as Hamet and Raschid ${ }^{3}$ is not unlike Hilpa, Harpath, and Shalum.4 Hawkesworth followed Johnson closely in these respects.

"Ingenious Hawkesworth to this school we owe And scarce the pupil from the tutor know." s

1 Only in so far as the moralistic tales composed by Addison and Johnson are concerned. Those referred to, pp. 80-81, ante, as adapted by Addison, possess intrinsic value.

${ }^{2}$ Leslie Stephen, Hours in a Library. Second Series. London, 1876, p. 211.

${ }^{3}$ Cf. p. 93, post. 'Cf. p. 83, ante.

- Courtenay, Verses on the Moral and Literary Character of Dr. Johnson, quoted by Boswell; Life of Johnson, edited by G. B. Hill. Oxford, 1887, Vol. I., p. 223. 
The only detailed description containing local colour is the picture of Bozaldab's son upon "the throne of diamonds." He is seated beside a princess "fairer than a Houri" and is surrounded by Rajahs of fifty nations. The hall is adorned with jasper statues and ivory doors with hinges of Golconda gold. A few customs are briefly mentioned, e.g. pressing the royal signet to the forehead in token of obedience, and meeting at the well in the desert where caravans stop. $^{1}$ Neither Johnson nor Hawkesworth attempts to localize the action beyond alluding to Bagdad, the plains of India, or "all the East."

One curious characteristic differentiating these two later essayists from Addison, is their far more elaborate care to adorn their narratives with what they style "the pompous language of the East." Orientalized phrases are found in Addison's tales, but are far simpler and less frequent. Hawkesworth carries the mannerism to extremes. "Amurath, Sultan of the East, the judge of nations, the disciple of adversity,

${ }^{1}$ The Story of Nouraddin and Amana, Adventurer, No. 72 (1753). This was one of the stories translated into French and published in Le Mercure de France. The French title was Les Souhaits Punis, Conte Oriental; date, August, 1760. 
records the wonders of his life." "As the hand of time scattered snow upon his head, its freezing influence extended to his bosom." The flutter of the Angel's wings is like "the rushing of a cataract," a beautiful valley is "the Garden of Hope," a dog is "thy brother of the dust." "Despair has armed [his hand] with a dagger." Figures of speech in Biblical phraseology are frequent, e.g. a smile "diffused gladness like the morning," "the straight road of piety," "the cup of consolation," the "Angel of Death came forward like a whirlwind." In Johnson's tales and to a certain extent in Hawkesworth's Carazan," the phrases are frequently dignified as well as sonorous, but in other tales by Hawkesworth and Warton the language is absurdly "elevated," - "the hoary sage"; "the fatal malignity," i.e. the cup of poison; "the screams of the melancholy birds of midnight that flit through the echoing chambers of the Pyramids." Such diction is noticeable in contrast to the plain English of Hawkesworth's non-oriental tales, e.g. the story of Melissa, ${ }^{2}$ and indicates unmistakably that "pompous language" was one essential in the eighteenth-

${ }^{1}$ Adventurer, No. 132.

${ }^{2}$ Ibid., Nos. 7 and 8. 
century concept of the oriental tale. This is the more curious, since in the genuine oriental tales known in England at the time Johnson and Hawkesworth were writing, such language is the exception rather than the rule. ${ }^{1}$ In the Persian Tales, for instance, the collection where one might expect to find figurative language, reference is made once or twice to the nightingale as lover of the rose, but figures such as the following are noticeably rare: "I lie down upon the thorns of uneasiness; the poison of your absence preys upon my heart and insensibly consumes my very life." "Your forehead is like a plate of polished silver; your brows resemble two spacious arches; your eyes sparkle beyond diamonds; . . . your mouth is a ruby casket that holds a bracelet of pearls." The rarity of such language is worth noting, for, as has been suggested, the later pseudo-orientalists thought they must fill their pages with such figures in order to be "oriental " - a delusion satirized by Goldsmith. "They believe," he says, "that in an oriental tale nothing is required but sub-

${ }^{1}$ Contrast the later oriental tales translated about the close of this period, e.g. the Persian Tales of Inatulla, which is exceedingly flowery in language. For full title, cf. App. B, II., No. 36, p. 301. 
limity ... all is great, obscure, magnificent, and unintelligible." 1

Not only in language, but also in incident, Hawkesworth is far more fantastic than either Addison or Johnson. Obidah, in Obidah, the son of Abensima, and the Hermit, an Eastern Story, ${ }^{2}$ follows a pleasant but misleading path, is overtaken by a storm, and meets a Hermit who preaches to him on the journey of life and the necessity of following the right road. The Story of the Shepherds Hamet and Raschid ${ }^{3}$ is equally brief and unintricate. The fields of the two shepherds, who lived on the plains of India, were suffering from drought. A genius appeared with the offer of gifts. Hamet asked a little, steady brook; Raschid demanded the Ganges. The moral is as prompt and complete as in an old-fashioned Sunday-school tale. Hamet's grounds prospered; Raschid's were swept away, and - "a crocodile devoured him"! Hawkesworth is not content with such childlike simplicity. His Ring of Amurath ${ }^{4}$ is as ingenious as it is moral. The sultan Amurath is presented

${ }^{1}$ Citizen of the World, Letter XXXIII. Cf. Chap. IV.

${ }^{2}$ Rambler, No. 65.

' Ibid., No. 38. 'Adventurer, Nos. 20, 21, 22. 
with a magic ring by a Genius, who warns him that the ring will grow pale and press his finger whenever he sins. Amurath degenerates into a cruel and sensual tyrant, vainly pursues Selima, the daughter of his vizier, throws away the painful ring, and is transformed by the Genius into a "monster of the desert." Captured and cruelly abused, he finally saves the life of his keeper, and in reward for this, his first good act, is changed into a dog. In this form, entering by chance the city of lawless pleasure, he beholds the horrors of unrestrained crime, and is poisoned. In his next form, that of a white dove, he reaches - again by chance - a hermit's cave, where he beholds Selima telling her story to the hermit. Amurath feels "the sentiments of pure affection" and, in consequence, resumes human shape. The hermit, who is the Genius, preaches a final sermon and dismisses them to reign over Golconda. They will now be happy, he says, because they have learned to be wise and virtuous. Equally fantastic and more fortuitous are the events in the sketch, Transmigration of a Soul, ${ }^{1}$ a story told by a flea, a realistic, disagreeable account of cruelties inflicted

${ }^{1}$ Adventurer, No. 5. 
by men on animals. Sometimes Hawkesworth's tales are free from grotesque fancies, e.g. the story of Carazan ${ }^{1}$ the miser, who dreams he is before the Judgment Seat and condemned to eternal solitude. He awakens, reforms, and gives a great feast to the poor. Such a tale is commonplace, but in its simplicity is not entirely unimpressive. In the majority of Hawkesworth's tales, however, the fantastic elements predominate.

Of Almoran and Hamet (1761), the best known of Hawkesworth's tales outside of the periodicals, much the same may be said. The story is similar to Nouraddin and Amana, but is more elaborate. The deus ex machina is a genius who gives supernatural aid to the tyrant Almoran in pursuing his evil desires. A magic talisman enables Almoran to assume other persons' forms, prodigies apparently from heaven alarm his opponents; yet each of his wishes is frustrated by the virtuous acts of his brother Hamet and the beautiful Almeida, until in the end he is metamorphosed into a rock, and they are left to reign in peace. The oriental colouring is thin and the characterization feeble. Yet the tale

1 Adventurer, No. 132. 
won, for a time, great popularity, due partly to the melodramatic interest, partly to the moralizing tone. ${ }^{1}$ The author discourses on the essentials of good government, the duties of a king, the question of immortality, and the idea that the pursuit of pleasure alone defeats its own end. In certain ways the story reminds one of Vathek and again of Seged." Almoran, like Vathek, longs for the gratification of every desire. "If I must perish," said he, "I will at least perish unsubdued. I will quench no wish that nature kindles in my bosom; nor shall my lips utter any prayer but for new powers to feed the flame." In answer to these words, the Genius appears, "one of those delusive phantoms, which, under the appearance of pleasure, were leading him to destruction." Like Seged, Almoran finds that the deliberate attempt to be happy at any cost ends in greater pain. Both tales represent an idea that was persistent in the philosophy of the eighteenth century, and was to find its most

${ }_{1}^{1}$ The Fair Circassian, a Tragedy, by Samuel J. Pratt, second edition, London, 1781; third edition, same year, was based on Almoran and Hamet. Cf. Preface, third edition. This must not be confused with The Fair Circassian, a dramatic performance by a gentleman-commoner of Oxford [Samuel Croxall] ... Taken from the Song of Solomon, 1755.

${ }^{2}$ Cf. p. 123, post. 
artistic expression in Rasselas and The Vanity of Human Wishes.

Two other moral tales, Langhorne's Solyman and Almena (1762), ${ }^{1}$ and Mrs. Sheridan's Nourjahad (1767), ${ }^{2}$ similar to Hawkesworth's stories, likewise enjoyed considerable popularity. Nourjahad narrates the experiences of a sultan's favourite, whose chief desires are inexhaustible riches and "prolongation of his life to eternity to enjoy them." The sultan causes the apparent fulfilment of these wishes, and Nourjahad rapidly degenerates through selfish indulgence in pleasures of the senses into an impious and murderous tyrant. His acts are accompanied by increasing unhappiness: the loss of his mistress, Mandana, the ingratitude of his son, the desertion of all his servants except one, Cozro, who acts as his conscience, recapitulates his sins, and demonstrates that, "by the immutable laws of Heaven . . . either in this world or the next, vice will meet its just reward." Cozro teaches the repentant Nourjahad the happiness that comes from generosity to the poor and suffering, and the faith in one's own rectitude and in

$$
\begin{aligned}
& { }^{1} \text { Cf. App. B, I., No. 52, p. } 284 . \\
& { }^{2} \text { Cf. App. B, I., No. } 57 \text {, p. } 285 .
\end{aligned}
$$


Heaven, that makes man superior to death. Nourjahad is finally brought to despise riches; to desire to save Cozro's life by losing his own; and, when that is unavailing, to accept the prospect of death rather than bribe his jailer. At the last moment the sultan reveals to Nourjahad that he has been disguised as Cozro, that Mandana still lives and has impersonated Nourjahad's guardian genius, and that the whole series of events has been arranged to test and to purify Nourjahad's character.

The story has a certain amount of interest. The illusion is well sustained, and the dénouement comes with considerable force. There is an attempt at oriental colouring in the descriptions of the omnipotent sultan, the forests and gardens, the mourning in the city for the sultan's death, the bribery of cadi and jailers, and the urns full of gold pieces and rare jewels in the subterranean treasure-vault. But the colouring is faint and serves only as a vague background for the story. There is unity in the development of the central idca of Nourjahad's evil desires, their result and his change of heart; there is, however, no real characterization. The burden of the moral and of the inflated, pompous diction is heavy, but the narrative is clear and often vivid. 
In Solyman and Almena the oriental colouring is paler even than in Nourjahad. "In the pleasant valley of Mesopotamia on the banks of the Irwan lived Solyman, son of Ardavan the sage," who worshipped the sacred Mithra. Names, places, mention of a few oriental customs like the suttee, occasional metaphors, suffice in the eyes of the author to make the tale oriental. His chief delight is to moralize and philosophize in gentle and leisurely fashion. The story begins with Solyman's desire to travel in order to gain knowledge of mankind and of God. It advances slowly because frequently broken by generalizations,' by descriptions of places like the "frowning" ruins of Persepolis and emotions aroused thereby, and also by digressions on the state of literature and manners in England. The extreme sentimentality of the lovers and their floods of tears often delay the progress of events. The language used is eminently suitable. When Solyman found that "to all the elegant graces of female softness, she [Almena] added the virtues of benevolence, his friendship for her was heightened into the most refined affection." On the whole, although the story is stiff, tedious, and over-moralistic, it has an attractive kind of 
purity and sweetness like the fragrance from an old-fashioned garden.

In many respects similar to the fiction discussed above, but superior in narrative directness and force is the moral tale by Miss Edgeworth, Murad the Unlucky. It was not published until 1804, ${ }^{1}$ and therefore would fall outside of our study, were it not so similar in character to the fiction under consideration. The starting-point of this story is a query by the Sultan of Constantinople concerning the tale of Cogia Hassan, the Rope-maker, and the Two Friends Saad and Saadi in the Arabian Nights. The Sultan, like Haroun Alraschid, is amusing himself by going at night, in disguise, through the streets of his city. Recollecting the tale of Cogia Hassan, he declares to his companion, the vizier, that "fortune does more for men than prudence." The vizier takes the opposite view and cites as instances two brothers, called Murad the Unlucky and Saladin the Lucky. The brothers recount the stories of their lives, and at the close the Sultan says to his vizier: "I acknowledge that the histories of Saladin the Lucky and Murad the Unlucky favour your opinion, that prudence

${ }^{1}$ In Popular Tales. Cf. App. B, I., No. 92, p. 292. 
has more influence than chance in human affairs. The succèss and happiness of Saladin seem to me to have arisen from his prudence: by that prudence Constantinople has been saved from flames and from the plague. Had Murad possessed his brother's discretion, he would not have been on the point of losing his head for selling rolls which he did not bake; he would not have been kicked by a mule or bastinadoed for finding a ring; he would not have been robbed by one party of soldiers or shot by another; he would not have been lost in a desert, or cheated by a Jew; he would not have set a ship on fire; nor would he have caught the plague, and spread it through Grand Cairo; he would not have run my sultana's looking-glass through the body, instead of a robber; he would not have believed that the fate of his life depended on certain verses on a china vase; nor would he, at last, have broken this precious talisman by washing it with hot water. Henceforward, let Murad the Unlucky be named Murad the Imprudent; let Saladin preserve the surname he merits, and be henceforth called Saladin the Prudent." 1 Such a

1 Popular Tales, by Miss Edgeworth. Philadelphia and New York, 1849, pp. 67, 68. 
quotation readily shows how far removed from the Arabian Nights were the moralistic tales, imitating, as they did, the manner only and not the spirit of their prototypes.

Of Ridley's Tales of the Genii (1764), ${ }^{1}$ the translation of Le Camus's Abdeker, or the Art of Preserving Beauty (1754), ${ }^{2}$ and The Vizirs, or the Enchanted Labyrinth, an Oriental Tale $(1774)^{3}$ by Mme. Fauques de Vaucluse, the same may be said with even greater emphasis. The subtitle of the first, "Delightful Lessons of Horam the Son of Asmar," betrays the author's purpose, which proves to be to disguise "the true doctrines of morality under the delightful allegories of romantic enchantment." The disguise is thin, though the "enchantment" is plentiful. Incantations, genii, sudden transformations, flowery valleys, crystal palaces, deserts, volcanoes, shipwrecks, are all lavishly employed. The attempt to accumulate horrors results once in unconscious humour: the description of the "horrid" sorcerer, who lurks in his lurid den, cherishing "his tube burning

1 Cf. App. B, I., No. 53, p. 284.

${ }^{2}$ Cf. App. B, I., No. 46, p. 282.

${ }^{3}$ Cf. App. B, I., No. 62, p. 286. 
with the fœtid herb tobacco, filling the cave with its poisonous odour." But the narratives, in general, are tedious, and the continual moralizing is anything but "delightful." Abdeker is also unimportant but curious - an awkward combination of an Eastern love-story with recipes for cosmetics and lectures on hygiene. The form is a frame-tale in which a few minor tales, such as Zinzima and Azor, are inserted. The Vizirs is a fanciful, tediously moralized story of the complicated adventures of several Eastern princes and princesses.

One curious instance of the general propensity to moralize is Dinarbas, a Tale, being a Continuation of Rasselas, Prince of Abissinia (1790). ${ }^{1}$ The idea of such a sequel was suggested to the author by Sir John Hawkins's statement that Dr. Johnson "had an intention of marrying his hero and placing him in a state of permanent felicity." The author's purpose is to show that love, friendship, and virtuous, altruistic conduct bring happiness. Rasselas is the hero of the book;

${ }^{1}$ Published anonymously; written by Ellis Cornelia Knight, "lady companion to the Princess Charlotte of Wales," and reaching its fourth edition by 1800 . Cf. App. B, I., No. 79, p. 290. On Rasselas, ef. Chap. III., post.

${ }^{2}$ Introduction to Dinarbas. 
Dinarbas is his friend. Rasselas quells a rebellion against his father, the Emperor; is falsely accused, imprisoned, and, by aid of Dinarbas, liberated; succeeds to the throne of Abyssinia, marries the sister of Dinarbas, and gives his sister Nekayah to Dinarbas. The story closes with their visit to the Happy Valley to set free its inhabitants. Throughout the book the author inculcates resignation, rectitude, courage, usefulness, and other virtues, and endeavours "to afford consolation or relief to the wretched traveler, terrified and disheartened at the rugged paths of life." Dinarbas is obviously inferior to its predecessor; its value is not literary but historical - as an evidence of the desire to moralize everything, even the philosophic tales.

It is not surprising to find in this period several editions of the Fables of Pilpay [or Bidpai], a version of the ancient Kalila and Dimna, which had been known in England since the Middle Ages. The moralistic note in addition to the perennial interest of these stories made an especial appeal to eighteenth-century readers. In 1743 appeared The Instructive and Entertaining Fables of Pilpay, an ancient Indian Philosopher, containing a number of excellent rules for the con- 
duct of persons of all ages. London, 1743. As early as 1711 there had appeared a book of extracts: Assop naturaliz'd: in a collection of diverting fables and stories from 'Esop, Lockman, Pilpay, and others. London, $1711 ; 1771 .{ }^{1}$

The name of the minor moralists of this period is Legion. It would be superfluous to do more than mention briefly the titles of a few works: Contentment, a Fable ${ }^{2}$ Hassan (178- ?) ; ${ }^{3}$ The History of Arsaces, Prince of Betlis by the editor of Chrysal (1774); ${ }^{4}$ The Caliph of Bagdad, Travels before the Flood, an Interesting Oriental record of men and manners in the antediluvian world interpreted in fourteen evening conversations between the Caliph of Bagdad and his Court, translated from Arabic (1796); ${ }^{5}$ The Grateful Turk, in Moral Tales by Esteemed Writers (1800 ?) $;{ }^{\circ}$ Hamet and Selinda an Eastern Tale. in The Baloon or crostatic Spy, a novel containing

${ }^{1}$ Cf. App. B, I., No. 10, p. 271.

${ }^{2}$ Bound in with The History of Abdalla and Zoraide, or Filial and Paternal Love. London, 1750. Cf. p. 71, ante, and App. B, I., No. 41, p. 281.

${ }^{3}$ Cf. App. B, I., No. 66, p. 287.

4Cf. App. B, I., No. 63 (a), p. 286.

- Cf. App. B, I., No. 86, p. 291, and Amorassan, p. 71, ante.

'Cf. App. B, I., No. 90, p. 292. 
a series of adventures of an aerial traveller (1786). ${ }^{1}$

In the last half of the century several collections of such oriental tales, chiefly moralistic, were made. "Mr. Addison's" Interesting Anecdotes, memoirs, Allegories, essays, and poetical fragments, tending to amuse the fancy and inculcate morality $(1797)^{2}$ in sixteen volumes, contains a great variety of oriental and unoriental tales taken, usually without naming the author, from the Rambler, the Adventurer, and other sources. A similar collection is The Orientalist, a volume of Tales after the Eastern taste, by the author of Roderick Random, Sir Lancelot Greaves, etc., and Others (1773). ${ }^{3} \quad$ Some of these tales are fanciful; many moralizing. One is a direct and unacknowledged translation of Marmontel's Soliman II. No authors' names are given. The tales are brief, uninteresting, and, with a few exceptions such as Soliman II., of little value. The tendency, found in France earlier in the century, to "moralize" oriental stories and fairy tales for the edification of children is exemplified by a

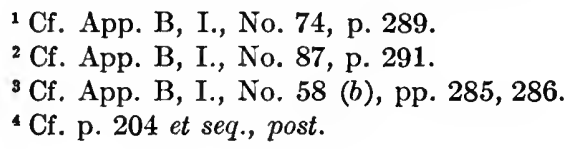


collection popular for several years after its publication: The Blossoms of Morality. Intended for the Amusement and Instruction of Young Ladies and Gentlemen by the Editor of the Looking Glass for the Mind (1789). ${ }^{1}$ In this collection are a few "oriental" tales, e.g. The Pleasures of Contentment, a "tedious brief" story of the good vizier Alibeg, unjustly exiled, discovered contentedly living as a hermit, surrounded by affectionate domestic animals. Recalled to office by popular demand, Alibeg sheds a few tears upon leaving his pastoral retreat, but returns to the city, rules wisely, and is content always and everywhere. The same collection contains An Oriental Tale; Generosity Rewarded; The Anxieties of Royalty; The Generous Punishment; - all, tales with "oriental" traces; - and The Beautiful Statue, a diluted version of the admirable tale of Zeyn Alasnam in the Arabian Nights, pitiably moralized. Finally, The Oriental Moralist appeared, in which "the Beauties of the Arabian Nights' Entertainments" were "accompanied with suitable reflections adapted to each story," by the Rev. Mr. Cooper (1790?). ${ }^{2}$

${ }^{1}$ Cf. App. B, I., No. 77, p. 289.

${ }^{2}$ Cf. App. B, I., No. 78, p. 290. 
The editor's preface needs no comment: "During a trip which I lately made to the Continent, I accidentally met with (at an Inn where I had occasion to halt a short time) a French edition of the Arabian Nights' Entertainments; having no other book at hand I was induced to wade through it. When I had finished . . . it struck my imagination, that those tales might be compared to a once rich and luxuriant garden, neglected and run to waste, where scarce anything strikes the common observer but the weeds and briars with which it is overrun, whilst the more penetrating eye of the experienced gardener discovers . . some . . . delightful flowers. Full of this idea, I determined to turn florist, and to traverse this wild and unweeded spot with a cautious and discriminating eye, . . . to cull a pleasing nosegay for my youthful friends. Quitting the simile, I have endeavoured to select a few of the most interesting tales, have given them a new dress in point of language, and have carefully expurgated everything that could give the least offense to the most delicate reader. Not satisfied barely with these views, I have added many moral reflections, wherever the story would admit of them. I have, in many instances, 
considerably altered the fables, and have given them a turn, which appeared to me the most likely to promote the love of virtue, to fortify the youthful heart against the impressions of vice, and to point out to them the paths which lead to peace, happiness, and honour." In accordance with this purpose Cooper gave the following new ending to Aladdin: "Sir, said the Sultana, after she had finished the story of the Wonderful Lamp, your majesty, without doubt, has observed, in the person of the African magician, a man abandoned to the passion of possessing immense treasures by the most horrid and detestable means. On the contrary, your majesty sees in Aladdin a person of mean birth, raised to the regal dignity, making use of the same treasures . . . just as he had occasion for them, or when an opportunity offered of applying them to the relief of the necessitous, or in rewarding industry and encouraging the practice of virtue." After that, the instant execution of the Sultana would have been, on the part of his majesty, justifiable homicide. Hawkesworth, in the concluding number of the Adventurer, confesses - hardly to the surprise of the reader who has perused the previous one hundred and 
thirty-nine essays - that he is a moral writer, and that he has found it necessary, in writing for "the Young and the Gay," to amuse the imagination "while approaching the heart." The editor of the Observer declares that simply to say that he has "written nothing but with a moral design would be saying very little, for it is not the vice of the time to countenance publications of an opposite tendency; to administer moral precepts through a pleasing medium seems now the general study of our essayists, dramatists, and novelists, ... . to bind the rod of the moralist with the roses of the muse." Beyond such didacticism no moralist could go.

If we pause to consider the Moralistic Group as a whole, our strongest impression is that of the general paucity of literary merit. Aside from Parnell's Hermit, Marmontel's contes, some of the tales quoted by Addison and Steele, and the Fables of Bidpai, there is nothing of noticeable intrinsic value. The moral oriental tales composed by Addison, Johnson, and Miss Edgeworth are the least valuable part of their work, far inferior, for instance, to the philosophic oriental tales, The Vision of Mirza and Rasselas. Only unusual genius can make an art of moralizing. 
Average writers, - like the authors of the fifteenth-century morality plays or the eighteenthcentury moralists when they turned to oriental fiction,-in their desire to express a universal truth concerning human character or conduct, eliminate so many individualizing traits that their personages become mere abstractions. They do not know the secret of embodying these abstract ideas in concrete and appropriate types, and hence their work lacks the beauty and universal human interest of the Pilgrim's Progress, the Faerie Queene, or the parables of Scripture. Yet the minor writers of any period - and the same is true of minor works by great writers - frequently reflect most clearly the current opinions of their age. ${ }^{1}$ For that reason the Moralistic Group of oriental tales possesses a distinct historical value.

1 "Yet for the real student, these secondary writers [e.g. Marmontel] . . . have, as they had for SainteBeuve, a peculiar interest. We see the movement, the drift, the line, in them more clearly than in their betters, precisely because it is less mingled with and distorted by any intense personal idiosyncrasy. They are not distractingly great nor distracted by their own greatness; they are clear if limited, comprehensible from beginning to end. The man of genius, being never merely, is never quite, of his time, the man of talent is." Professor Saintsbury's Introduction to Marmontel's Moral Tales. . . . London, 1895, p. xiv. 


\section{CHAPTER III}

\section{THE PHILOSOPHIC GROUP}

The Philosophic Group of oriental tales is in number far smaller and in literary value far more considerable than the Moralistic. Here, again, Addison was the guide, using several oriental stories to illustrate philosophical ideas and composing one famous oriental tale, or rather sketch, The Vision of Mirza. ${ }^{1}$ The Vision is so familiar and so accessible that any detailed account of it would be superfluous. Mirza, from the topmost pinnacle of the high hills of Bagdad, beholds multitudes passing over the bridge of life, which spans a part of the great tide of eternity. Sooner or later all fall from the bridge and are borne out into the thick mist toward either the islands of the blest or the dark clouds beyond the rock of adamant. By means of this vision, Mirza realizes the vicissitudes of life, the certainty of death, the consolation of

${ }^{1}$ Spectator, No. 159. 
faith, and the mystery enveloping man's existence. It is Addison's way of saying "From the great deep to the great deep he goes." 1 The form of the Vision is simplicity and clearness itself. The language, lucid and direct, displays Addison's characteristic restraint in the use of oriental ornament and imagery. The literary value of The Vision of Mirza as an oriental tale lies less in the specific detail of oriental colouring than in the general impression of beauty and of awe. "But instead of the rolling tide, the arched bridge, and the happy islands, I saw nothing but the long hollow valley of Bagdat, with oxen, sheep, and camels, grazing upon the sides of it," - a serene English valley, orientalized only by the name Bagdat and the presence of the camels. And yet, if the oriental elements were cut away from The Vision of Mirza, the picturesque attributes of the central metaphor, the bridge of human

1 One is reminded also of the Anglo-Saxon story of the sparrow flying through the lighted hall from darkness to darkness again, as a type of human life; and of the inscription on the Taj Mahal: "This world is only a bridge; therefore eross over it, but build not upon it. The future is veiled in darkness, and one short hour alone is given thee. Turn every moment into prayer if thou wouldst attain unto Heaven." 
life, would go, for they are drawn from the Mahometan tradition of the bridge "Al Sirát," laid across hell, "finer than a hair and sharper than the edge of a sword," over which the souls of men pass, - the good to the Mahometan paradise, the wicked to hell, which is encircled by a wall of adamant. Moreover, the quiet, cumulative force of one slight stroke of oriental imagery after another produces a sense of remoteness and stimulates the imagination, especially when the phrases echo Biblical cadences and thus attain an added solemnity. "'Surely,' said I, 'man is but a shadow and life a dream....' 'The valley that thou seest,' said he, 'is the vale of misery, and the tide of water that thou seest, is part of the great tide of eternity. . . .' 'I wished for the wings of an eagle that I might fly away to those happy seats; but the genius told me there was no passage to them except through the gates of death.'"

The other philosophic oriental tales in the Addisonian periodicals illustrate various themes: the transitoriness of life, the subjectivity of time, personal identity, and so on. Frequent phrases suggest that in oriental thought and imagery 
what appealed most forcibly to Addison's reverent nature was "likeness to those beautiful metaphors in scripture." 1 One brief story is told by him to illustrate the figure "where life is termed a pilgrimage, and those who pass through it are called strangers and sojourners upon earth," and to conclude an essay on the value of contemplating the transitoriness of human life. A dervish mistakes a palace for an inn, and when the king asks an explanation, replies by a series of questions leading up to an admirable climax. "'Sir,' says the Dervish, 'give me leave to ask your Majesty a question or two. Who were the persons that lodged in this house when it was first built?' The King replied, his ancestors. 'And who,' says the Dervish, 'was the last person that lodged here?' The King replied, his father. 'And who is it,' says the Dervish, 'that lodges here at present?' The King told him that it was he himself. 'And who,' says the Dervish, 'will be here after you ?' The King answered, the young Prince, his son. 'Ah, Sir,' said the Dervish, 'a house that changes its inhabitants so often and receives such a perpetual succession of guests, is not a Palace, but

${ }^{1}$ Spectator, No. 289. 
a Caravansary."' 1 The oriental colouring here is slightly stronger than in The Vision of Mirza. The dervish, "traveling through Tartary," arrived "at the town of Balk, . . . laid down his wallet and spread his carpet in order to repose himself upon it, after the manner of Eastern nations." The notion of the subjectivity of time as set forth by Locke is exemplified in the account of Mahomet's journey to the seven heavens in the twinkling of an eye, ${ }^{2}$ as well as by the adventures of the Sultan of Egypt. ${ }^{2}$ The latter story, drawn from the Turkish Tales, is interestingly told, though shorn of most of its picturesque details. From the Persian Tales an unknown contributor to the Spectator takes the story of Fadlallah and Zemroude, and introduces it by a quotation from "Mr. Locke" on personal identity and by these remarks: "I was mightily pleased by a story in some measure applicable to this piece of philosophy, which I read the other day in the Persian Tales, as they are lately very well translated by Mr. Philips . . . these stories are

${ }^{1}$ Spectator, No. 289; attributed by Addison to the travels of Sir John Chardin.

${ }^{2}$ Spectator, No. 94. 
writ after the Eastern manner, but somewhat more correct." ' The writer chastens the style of his quotation still further by eliminating many of the imaginative elements for the sake of the "piece of philosophy." The idea of perpetual suspense is illustrated by reference not only to the mediæval ass between two bundles of hay but also to Mahomet's coffin suspended in midair by magnets. ${ }^{2}$ The misery and ingratitude of humanity is shown by a vision. ${ }^{3}$ The conception of the development of philosophy and virtue in a man on a desert island, guided by "the pure light and universal benevolence of nature," is given as a quotation from an Arabian author. It calls to mind Mrs. Behn's Oroonoko and his successor, the "natural man" of the eighteenth century. In all these narratives or fragments of narratives the tone is speculative rather than directly didactic, but all except Fadlallah and Zemroude are used to point a moral. With one exception, all the

${ }^{1}$ Spectator, No. 578.

${ }^{2}$ Spectator, No. 191.

3 Spectator, No. 604.

"Guardian, No. 61 (Pope). The story is probably The Life of Hai Ebn Yokdhan, cf. p. 126 et seq., post. Pope also quotes the tale of the Traveler and the Adder, which he calls "one of the Persian fables of Pilpay." 
philosophical and moral ideas in the twenty-nine oriental tales found in these early periodicals, from the opening number of the Tatler, in 1709, to the last issue of the Freeholder, in 1716, are either noticeably English in character or else universal ideas, common to English and oriental thought. The one exception ${ }^{1}$ is the doctrine of transmigration of souls, which has been attributed to oriental philosophy. Yet this doctrine is Pythagorean as well as oriental, and the ultimate source, though possibly oriental, is unknown. In general the philosophizing in the periodicals is along the lines of universal thought, expressed in a thoroughly English and Addisonian manner.

In the philosophic as in the moralistic tales the most famous of Addison's successors was Dr. Johnson. As suggested above, ${ }^{2}$ the difference in temperament between the two men is clearly reflected in their periodicals. Addison's

${ }^{1}$ Spectator, No. 343 . At the opening of this essay Addison makes Will Honeycomb quote Sir Paul Rycaut's account of Mahometan beliefs, including transmigration. The story of Pug's adventures resembles that of the transmigrations of Fum Hoam (Chinese Tales, cf. Chap.

I I., ante). The idea of metempsychosis was a favourite one in the early eighteenth century, witness Fielding's Journey from this World to the Next. $\quad{ }^{2}$ p. 89. 
lighter touch and buoyant spirit are replaced in the Rambler and the Idler by Johnson's heavier style and more uniformly serious purpose. And yet the Rambler and its imitators have much in common with the earlier group. The similarity is especially noticeable in those parts of Johnson's work that are deliberate and conscious imitations. Addison had used the oriental tale among other devices to convey instruction under the guise of amusement; Johnson did likewise. The story of Ortogrul of Basra ${ }^{1}$ distinctly recalls Addison's oriental tales. The scene is laid in Bagdad, and the narrative opens with an account of Ortogrul wandering in "the tranquillity of meditation" along the streets. $\mathrm{He}$ is taught the value of slow and constant industry by a dream, in which, like Mirza, he beholds a vision from a hilltop. The genius in Mirza is replaced by the father of Ortogrul, who directs the latter's gaze to an ineffectual torrent and to a slow but sure "rivulet," and points the moral. For local colour in these tales Johnson is satisfied with vague allusions such as that to the vizier's return from the divan to spacious apartments in his palace, hung with golden ${ }^{1}$ Idler, No. 99. 
tapestry and carpeted with silk. Dates, places, and oriental customs are likewise indistinct. "In the reign of Zenghis Can," "Samarcand," "Arabia," "the emirs and viziers, the sons of valour and of wisdom, that stand at the corners of the Indian throne, to assist the Councils," such brief references suffice for Johnson's purpose. Like Addison, too, Johnson feels that an. oriental tale demands elevated and dignified diction, Biblical imagery, and the abstract, general term instead of the concrete.

But there the likeness ends, for Johnson's early oriental tales, far more than any of his other writings, are embellished with peculiarly Johnsonian Latin derivatives and resounding antitheses. Sometimes the style gains by these means the added force and dignity purposed by the author. "In the height of my power, I said to defamation, who will hear thee? and to artifice, what canst thou perform?" ... "The clouds of sorrow gathered round his head." But often this attempt at rhetorical ornamentation results in bombast and unintentional humour: "The curls of beauty fell from his head;" "the voracious grave is howling for its prey;" "he practised the smile of universal 
courtesy;" "a frigorific torpor encroaches upon my veins." In Ortogrul, Johnson goes even to this extreme in describing the rich vizier's life: "The dishes of Luxury cover his table, the voice of Harmony lulls him in his bowers; he breathes the fragrance of the groves of Java, and sleeps upon the down of the cygnets of Ganges." Grandiloquence of this sort takes the place of detail in description. When Johnson wishes to depict an Eastern princess, he portrays her "sitting on a throne, attired in the robe of royalty, and shining with the jewels of Golconda; command sparkled in her eyes and dignity towered on her forehead." Such a description is eminently in keeping with Johnson's didactic purpose. Didactic in the Rambler Johnson always is. "Instruction," in Boswell's words, "is the predominant purpose of the Rambler," 1 - instruction, whether directly inculcating morality, as in the moralistic tales, or indirectly setting forth some philosophic idea connected with human conduct, as in the six so-called philosophic tales. Yet, even in the latter group, Johnson's speculation is always

${ }^{1}$ Life of Johnson, edited by G. B. Hill. Oxford, 1887, Vol. I., p. 215. 
concerned with questions of vital interest to mankind, and hence in the deepest sense moral questions. In all of his fiction, moralistic teachings are present, whether explicit or implicit, although less prominent than the philosophic ideas.

Frequently pompous in diction and artificial in manner, these stories, nevertheless, do not lack a certain impressive simplicity in their presentation of various aspects of Johnson's earnest philosophy of life. His convictions of the vanity of accumulating riches, expecting gratitude, seeking happiness, desiring fame, forming a definite plan for one's life, are all found here and are all variations on his favourite theme: the vanity of human wishes. But, even in these short stories, Johnson reveals two other equally characteristic aspects of his philosophy: religious faith, and brave insistence on duty. Nouradin the Merchant and his son Almamoulin, which forms the whole of the Rambler, No. 120, is prefaced by quotations on virtue, and teaches the vanity of gathering riches. Morad the son of Hanuth and his son Abonzaid ${ }^{1}$ sets forth the vanity of labours that wish to be rewarded by

${ }^{1}$ Rambler, No. 190. 
gratitude, and concludes that the only satisfactory aim of life is to please God. Seged, Lord of Ethiopia, and his efforts to be happy, ${ }^{1}$ is obviously an earlier draft of Rasselas.' Seged, having fulfilled all his duties as king, determined to retire for ten days from the cares of state, in order to be happy for that short interval. $\mathrm{He}$ commanded "the house of pleasure built in an island of the Lake Dambia, to be prepared," and endeavoured to gratify every desire. But the first day there were so many pleasures to choose from that the day slipped by without a choice; and the other days were marred by accidents, a bad dream, tyranny, envy among those whom he sought to please, by the memory of a defeat, and finally by the death of his daughter. Hence the king concluded: "Let no man ever presume to say, "This day shall be a day of happiness." " The narrative is better

1 Rambler, Nos. 204, 205.

2 In a Voyage to Abyssinia, by Lobo, a Portuguese Jesuit, which Johnson translated, 1735, from a French version, mention is made, Chap. X., of Sultan Segued, Emperor of Abyssinia, "the much-talked-of lake of Dambia," and the bridge built across the Nile by Sultan Segued. Neither in the edition of Rasselas by G. B. Hill nor in that by James Maeaulay is the resemblance between Seged and Rasselas noted. 
than in the other tales; it possesses more unity and more interest. The oriental setting is slight, the descriptions are vague, and emphasis is thrown upon the unadorned theme. The strength of the story lies in the force of this theme and the sympathetic account of Seged's successive feelings. It is interesting to find Johnson meditating on these questions seven years before writing Rasselas. Two other tales, published after Rasselas, treat of similar ideas. Gelalledin $^{1}$ is like a part of the story of Imlac in Rasselas. Gelalledin, the learned youth, refused a professor's chair in hopes of returning to his native city "to dazzle and instruct," but when he returned, was unnoticed and ignored. Omar, Son of Hassan, ${ }^{2}$ the good and wise servant of the caliph, tells the plan he made in youth for his life: ten years study; ten years travel; marriage, and retirement from court. But he "trifled away the years of improvement," and each part of his plan was frustrated. Terrestrial happiness is short, and it is vanity to plan life according to one's wishes, - surely an echo of the theme of Rasselas.

The imitators of Johnson apparently found it

1 Idler, No. 75.

${ }^{2}$ Idler, No. 101. 
easier to write moralistic than philosophic tales. At least this is true of the editor of the Adventurer, who was so voluminous a moralist. Only one of his stories, Almet the Dervise, ${ }^{1}$ can be called philosophic, and even here the author moralizes throughout. The title given the essay is The Value of Life fixed by Hope and Fear and therefore dependent upon the Will: an Eastern story. Almet is taught by an angel, who shows him in a vision a fair landscape and an "austere" scene and comments on them. Like Johnson, Hawkesworth employs oriental colouring sparingly. He exerts his imagination upon the picture of the dervish Almet watching the sacred lamp in the sepulcher of the prophet and, after the angel has vanished, finding himself at the temple porch in the serene twilight. One other imitation of Johnson's philosophic tales is Goldsmith's Asem, an Eastern Tale: or a vindication of the wisdom of Providence in the moral government of the world. ${ }^{2}$

1 Adventurer, No. 114.

2 Published in Essays by Dr. Goldsmith, 1765 (N.B., the Preface says: "The following essays have already appeared at different times and in different publications"); to be found in The Bce and other Essays by Oliver Goldsmith. . . . London and Philadelphia, 1893, p. 187. 
Asem is taught by the customary vision and Genius. Goldsmith's fancy, not content with the conventional introduction, pictures the Genius walking over the lake and guiding Asem to a beautiful country beneath its depths. The lucid style and the occasional satire, characteristic of the author, serve to distinguish this sketch from those of his predecessors.

We have spoken of the development of the philosophic oriental tale from Addison's Vision of Mirza on through Johnson's work in the Rambler and the Idler to Hawkesworth's and Goldsmith's imitations. There remain to be considered the translations from Voltaire, especially Zadig, and the most important philosophical oriental tale of the period, Johnson's Rasselas. But before examining these books, which carry on the philosophizing tendency to its culmination, it may be well to mention two works, somewhat apart from the general current, yet warranting a brief digression.

One is a pseudo-translation: The Bonze, or Chinese Anchorite; ${ }^{1}$ the other, a genuine translation from the Arabic, The Life of Hai Ebn Yokdhan.

${ }^{1}$ The Bonze, or Chinese Anchorite, an Oriental Epic Novel. Translated from the Mandarine language of 
The full title of the latter reads: ${ }^{1}$ The Improvement of Human Reason, Exhibited in the Life of Hai Ebn Yokdhan: Written in Arabick above 500 years ago, by Abu Jaafar Ebn Tophail, In which is demonstrated, By what Methods one may, by the meer Light of Nature, attain the Knowledg of things Natural and Supernatural; more particularly the Knowledg of God, and the Affairs of another Life, Illustrated with proper Figures. Newly Translated from the Original Arabick, by Simon Ockley, A. M. Vicar of Swavesey in Cambridgshire. With an Appendix, In which the Possibility of Man's attaining the True Knowledge of God, and Things necessary to Salvation, without Instruction, is briefly consider'd. London ... 1708. The bookseller's preface to the reader summarizes the author's purpose and outlines the story with sufficient

Hoamchi-vam, a Tartarian Proselite, by Mons. D'Alenzon, Dedicated to Lord Kilwarling Son and Heir of the Earl of Hillsborough, Secretary of State for the Northern Colonies. With Adventurous wing exploring new found Worlds, the Orient Muse unfettered with Rhyme who Sings of Heaven, of Earth, and Wondrous mutations; Strives to Mingle instruction with delight, in hope to gain the smile of Approbation. Two vols. London, 1769.

${ }^{1}$ The original spelling is preserved in the quotations given from this work. Cf. App. B, I., No. 8, p. 270. 
clearness: "The Design of the Author (who was a Mahometan Philosopher) is to shew how Humane Reason may, by Observation and Experience, arrive at the Knowledge of Natural Things, and from thence to Supernatural; particularly the Knowledge of God and a Future State. And in order to [do] this, he supposes a Person brought up by himself, where he was altogether destitute of any Instruction, but what he could get from his own Observation. He lays the scene in some Fortunate Island, situate under the Equinoctial; where he supposes this Philosopher, either to have been bred (according to Avicen's Hypothesis, who conceiv'd a Possibility of a Man's being form'd by the Influence of the Planets upon Matter rightly disposed) without either Father or Mother; or else expos'd in his Infancy, and providentially suckled by a Roe. Not that our Author believ'd any such matter, but only having design'd to contrive a convenient place for his Philosopher, so as to leave him to Reason by himself, and make his Observations without any Guide. . . . Then he shews by what Steps ... he advanc'd . . . till at last he perceived the Necessity of acknowledging an Infinite, 
Eternal, Wise Creator, and also the Immateriality and Immortality of his own Soul, and that its Happiness consisted only in a continued Conjunction with this supream Being." The bookseller continues with a comment to which the reader will assent: "The Matter of this Book is curious." One interesting description of the solitary hero's method of making himself comfortable on the island recalls Robinson Crusoe, and as this book appeared only eleven years before Crusoe, the passage may possibly have been seen by Defoe. Hai Ebn Yokdhan, by the time he was twenty-one years old, "had made abundance of pretty Contrivances. He made himself both Cloaths and Shoes of the Skins of such Wild Beasts as he had dissected. His thread was made of Hair, and of the Bark of ... Plants. . . He made awls of sharp Thorns. . . . He learn'd the Art of Building from the Observations he made upon the Swallows Nests. ... He . . made a Door ... of Canes twisted together . . . etc." ${ }^{1}$ One other passage of interest is the account of his mystical trance. ${ }^{2}$ He prepared himself by abstinence and by "Imitation of the Heavenly ${ }^{1}$ p. 57 , edition of $1708 . \quad{ }_{\mathbf{K}}^{2}$ pp. 114-139, same edition. 
Bodies" in three respects, first in exercising beneficence toward animals and plants, second in keeping himself "clear, bright, and pure" like the light, third in "practising a circular motion" until dizziness weakened his bodily faculties and purified his spirit. ${ }^{1}$ By such means and by constant meditation, he at last attained to the sight of perfect vision in the highest sphere. There he beheld the reflection of the divine glory, the perfection of beauty, splendour, and joy; and after that, the successive reflections of the divine essence in the other heavenly spheres. Thus he came to realize the dependence of all created things on the "one, true, necessary, self-existent" First Cause: and saw that this world followed "the Divine World as a Shadow docs the Body." The story concludes with an account of the friendship formed by the philosopher with a holy man who came to the island, and of their "serving God . . . till they died." In addition to the slight resemblance to Robinson Crusoe noted above, the book possesses interest as a link between the work of seventeenthcentury orientalists like Dr. Pococke ${ }^{2}$ and the

${ }^{1}$ Cf. the dancing dervishes.

${ }^{2}$ Dr. Edward Pococke (1604-1691) wrote a preface to a Latin translation of Hai Ebn Yockdhan, published, Oxford, 1671, by his son Edward Pococke (1648-1727). 
oriental tales of our period; and also as an example of the exaltation of the "natural man" found earlier in Oroonoko and later in the works of Rousseau.

The Bonze is more curious but less valuable. It is an odd medley of moralistic and philosophic rhapsodies on all sorts of subjects, the Trinity, Lucifer, Adam's fall, - combined with sentimental and coarse love-tales concerning the Chinese prince Zangola's transmigrations, and recounted in a vision to the sage Confuciango. The style is so atrocious as to be amusing, e.g. the "gay pomposity" of the peacock's "beauteous tail," "horrific scenes," "old dreadful tygers" [sic], the "elegance of heaven," and "the hideous tenebrosity of hell." "Elegance" of every kind is frequent. "Never before was my heart susceptible of such elegant feelings." "Methought mortality fell from me like the catterpiller's [sic] form, when he becomes invested with elegance, and shaking his golden wings, disclaining earth, he flies exulting towards heaven." But when the writer goes so far as to describe "a sunrise, orientally decorated," one is irresistibly reminded of Fielding's cheerful parodies of flamboyant preambles 
in, for example, the opening paragraph of Chap. II., Book IV., of Tom Jones: "A short hint of what we can do in the sublime, and a description of Miss Sophia Western." The Bonze in extravagance thus occupies a unique, if insignificant, place among the philosophic tales. Like them it discusses questions such as the origin of evil and the search for happiness, attempts but little local colour, and regards the East as "romantic" and "barbaric," words at that time almost synonymous. "He received me in as kind a manner as it is possible for a mere barbarian." "There was a romantic palace in the free taste of China, which, tied to no partial rules, admitted all the beauties of architecture." The attitude of the writer is one of apologetic admiration of objects and ideas so foreign to eighteenth-century standards. But The Bonze, despite its aim to "mingle instruction with delight in hope to gain the smile of approbation," stands at one side in any general view of the philosophic oriental tale, and serves to bring into greater prominence the real value of such works as Voltaire's Zadig and Johnson's Rasselas.

In France, the Conte Philosophique, founded 
by Voltaire, had been one of the most notable imitations of the genuine oriental tale. In 1749, only a year after the first complete French edition appeared, $Z_{a d i g}{ }^{1}$ was translated into English. The popularity it attained in England was due in part to the fact that one of its chapters, The Hermit, was based on the poem by Thomas Parnell, ${ }^{2}$ in part to the fame of Voltaire, and chiefly to the character of the book itself. Abounding in wit, humour, and philosophy, - qualities enhanced by Voltaire's keen and brilliant style, - Zadig has a permanent value, visible even through the medium of translation. There is a slight but sufficiently firm thread of story, - the love of Zadig for the queen, - and on this are strung Zadig's separate and vari-coloured adventures. The discovery of the king's lost palfrey by circumstantial evidence, Zadig's pretense at worshiping candles to rebuke his idolatrous master, the

${ }^{1}$ Zadig, or the Book of Fate, an Oriental History translated from the French original of Mr. Voltaire. London ... 1749. Several other editions appeared later in the century, and one chapter, The Hermit, separately, e.g. 1779. Cf. App. B, I., No. 39 (a), p. 279; and No. 39 (j), pp. 280, 281.

2 Cf. pp. 77-79, ante. Parnell's poem was one of the sourees, not the only source, of Voltaire's chapter. 
frustrated attempt of Zadig's affectionate wife to cut off his nose, his rescue from death by a parrot's finding his verses, the fantastic scene of the maidens in a meadow searching for a basilisk, - such incidents are cleverly told, and even in the English version show something of the wit of the original French. The main story has a good climax and a happy dénouement. Voltaire's clever manipulation of oriental colouring apparently contributed not a little to the immediate popularity of both the French and the English versions. By the time Zadig appeared,' the European critic of manners and thought in the disguise of an Oriental had become a conventional type in the oriental tale. ${ }^{2}$ Zadig is a variant on the theme of the Lettres Persanes. Voltaire is a more subtle satirist in that he does not locate his Oriental in Paris, but in Babylon. Hence, like Swift's satires, Voltaire's criticisms of European customs, because ostensibly remote and not aimed at Europe, are the more penetrating. "That show of insignificant words which in Babylon they called polite conversation."... "They would not

${ }^{1}$ In French, 1747, 1748; in English, 1749.

${ }^{2}$ Cf. Chap. IV., p. 155 et seq., post. 
suffer him to open his mouth in his own vindication. His pocket-book was sufficient evidenee against him. So strict were the Babylonish laws." Zadig is, of course, Voltaire himself, and the other characters with fanciful "oriental" names - Arimanzes, Astarte, Seloc - are said to be Voltaire's court enemies and friends. Like the similar device in the pastoral, this gave piquaney to the narrative. Voltaire's twofold aim, to be the entertaining story-teller and the satirieal philosopher, is diseernible on every page, and his light and faeile use of oriental setting is not unlike Goldsmith's in The Citizen of the World. He lays the scene in Babylon or Egypt, the Indies or Memphis, and mentions Siberia and Seythia to add to the sense of remoteness. His characters wear turbans and sandals, travel on the "swiftest dromedaries" and camels, are sold as slaves to an Arab merchant, are threatened with the bowstring and poisoned cup. The "fair coquet" insists that the old and gouty chief Magus shall "dance a saraband" before her, and the beautiful Almona is rescued from the suttee by the ability of Zadig. Besides such references to Eastern customs, there are quotations of prov- 
erbs and of Zoroastrian precepts, and various references to religious beliefs and observances, e.g. the bridge of death, the angel Azrael, Oromazdes, and temple worship. Chap. XI., The Evening's Entertainment, treats of ideas found also in Voltaire's Fragments historiques sur l'Inde: the worship of one God under the symbol of fire by the ancient Persians; of one supreme Deity under various symbols by the Egyptians, etc. A heated discussion takes place between an Egyptian, an Indian, a Greek, and others as to the superior claims of their respective religions. They are finally brought by Zadig's sense and tact to acknowledge that, in truth, they all worship the Supreme Creator as behind and above all symbols. ${ }^{1} \quad$ By this mockery of oriental fanaticism, Voltaire is actually satirizing European bigotry and unreason. In a similar manner he strikes at the metaphysicians. Zadig "was well instructed in the science of the ancient Chaldeans ... and understood as much of metaphysics as any that have lived after him, - that is to say, he knew very little about it." And, aiming ostensibly at the mercenary

${ }^{1}$ Cf. Lessing: Nathan der Weise (apologue of the three rings). 
selfishness of the Babylonian courtiers, Voltaire hits the sycophants of the French court. The king ordered Zadig's fine of four hundred ounces to be restored to him. "Agreeable to his Majesty's commands, the clerk of the court, the tipstaffs, and the other petty officers, waited on Zadig . . . to refund the four hundred ounces of gold; modestly reserving only three hundred and ninety ounces, to defray the fees of the court and other expenses." The inconsistency of the oriental freebooter who thought it wrong for the rich, but quite right for himself, to get and keep wealth, might easily have found a parallel in France. "I was distracted to see" (he says) "in a wide world which ought to be divided fairly among mankind, that Fate had reserved so small a portion for me." Other themes illustrated are the misery caused by. tyrants; the injustice of the social structure; the fickleness of women who protest too much; and above all the question of the part played in human life by destiny, - the apparent supremacy of Chance, and the real supremacy of a foreknowing and overruling Providence. Zadig's adventures hinge upon trivial happenings, and hence he doubts Providence, until the 
angel, disguised as a hermit, teaches him. ${ }^{1}$ We have spoken of Voltaire's facile use of oriental colouring. But in Zadig few figures of speech occur. On one occasion Zadig addresses the judges as "glorious stars of justice," and "mirrors of equity." Such figures, however, are rare, a fact the more remarkable since Voltaire considered the immoderate use of metaphor one of the chief characteristics of oriental writing, ${ }^{2}$ and another instance of the way in which he subordinated the oriental setting to his serious purpose.

Besides Zadig, several other contes philosophiques by Voltaire were early translated into English. In the majority of them, literary and social satire predominates over philosophical speculation, and therefore these tales may best be classified among the Satiric Group in Chap. IV. But in two, though satire is present, speculation is predominant: The World as it Goes,

${ }^{1}$ Cf. W. Seele, op. cit., p. 77, n. 4, ante, in which, on p. 64, reference is made to the high estimation by Gaston Paris, of Zadig as the most beautiful of Voltaire's romances, and of the "Hermit" as the best chapter in Zadig.

${ }^{2}$ Cf. "On a Passage in Homer" under "Ancients and Moderns" in Voltaire's Philosophical Dictionary, tr. by W. F. Fleming, Vol. I., Paris, London, New York, Chicago, 1901. 
(1754) ${ }^{1}$ and The Good Bramin (1763). ${ }^{2}$ Both are brief. The latter is a sketch of a good Bramin who had studied much and, in his own estimation, learned nothing. Hence he was unhappy, yet he preferred his condition to that of an old woman, who lived near him, contented because ignorant. In conclusion the author states that he has been unable to find any philosopher who would accept happiness on the terms of being ignorant. All men seem to set a greater value on reason than on happiness. Is not that folly? The World as it Goes is an account of a visit to Persepolis, i.e. Paris, by Babouc the Scythian, sent by the genie Ithuriel to observe the inhabitants in order to assist Ithuriel in deciding whether or not to destroy Persepolis. Babouc observed soldiers, church-goers, lawyers, merchants, magi, men of letters, and women. In . each group he found both good and bad qualities so mingled that he wavered back and forth in his judgment, and finally grew fond of a city, "the inhabitants of which were polite, affable, and beneficent, though fickle, slanderous, and vain." When obliged to report to the angel, he

$$
\begin{aligned}
& { }^{1} \text { Cf. App. B, I., No. } 39(b), \text { p. } 279 . \\
& { }^{2} \text { Cf. App. B, I., No. } 39(f) \text {, p. } 280 .
\end{aligned}
$$


presented him with a little statue made of base metals, gold, and jewels. "Wilt thou break," said he to Ithuriel, "this pretty statue because it is not wholly composed of gold and diamonds?" Ithuriel understood, and resolved to spare the city and to leave "the world as it goes." "For," he said, "if all is not well, all is passable." Except for these contes by Voltaire, no philosophic oriental tales of any importance were translated from the French. The current tended, in fact, the other way. English tales, both moralistic and philosophic, were translated and adapted for use in Les Mercures de France.

Of the philosophic oriental tales composed in English, Rasselas (1759), ${ }^{1}$ the most important, remains to be discussed. The culmination of the fiction in the Rambler and the Idler, this brief sketch may be regarded as the best type of the serious English oriental tale. Written immediately after the death of Johnson's mother, it expresses the substance of the author's somber philosophy of life. Though darkened by his immediate grief, the philosophy is essentially the same as that revealed in his conversations ${ }^{1}$ Cf. App. B, I., No. 40, p. 281. 
and his verse. The theme of the tale can hardly be stated in a better phrase than "The Vanity of Human Wishes." Rasselas, confined in the Happy Valley all the days of his youth, realizes that the gratification of desire does not confer lasting happiness; and, with his sister Nekayah and two other companions, escapes into the world only to discover unhappiness everywhere. Unable to obtain even his wish to govern a little kingdom beneficently, he resolves to return to Abyssinia. In sight of this conclusion, the princess Nekayah significantly declares: "The choice of life is become less important. I hope hereafter to think only on the choice of eternity."

The story is broken by continual philosophizing, or rather the philosophizing - to the author more important - is held together by the slender thread of narrative. Serious and leisurely conversations held by Rasselas with his companions turn upon the problems of government; the characteristics of melancholia; the mysterious causes of good and evil; the immortality of the soul; and, most frequently, the impossibility of attaining happiness. One of the chief reasons for discontent is the lack of 
free choice. "Very few . . . live by choice.

Every man is placed in his present condition by causes which acted without his foresight and with which he did not always willingly coöperate; and therefore you will rarely meet one who does not think the lot of his neighbours better than his own." Each endeavour of Rasselas to find a happy man is unsuccessful. "The young men of spirit and gaiety," whose only business is pleasure, are not happy; shepherds in the much-praised pastoral life and courtiers in gay society are envious and discontented; hermits are at heart unhappy, and so are the sages who trust in empty and eloquent commonplaces on the superiority of reason; men who advise living "according to nature" attain only a false content. "Marriage has many pains, but celibacy has no pleasures;" old age is darkened by loneliness and disappointed hopes; happiness itself is the cause of keenest misery to the man who has loved and lost a friend, and "human life is everywhere a state in which much is to be endured and little to be enjoyed."

The mitigating circumstance which affords this little enjoyment is the power of man to attain knowledge and to retain integrity. An 
educated intellect and a quiet conscience go far, in Johnson's estimation, towards winning serenity and patience. "Knowledge" includes poetry; the poet Imlac is a man of learning, a scholar; and poetry is "considered as the highest learning and regarded with a veneration. . . ." The poet should educate himself by study and by observation until he is able to fulfil his function "as the interpreter of nature and the legislator of mankind, ... presiding over the thoughts and manners of future generations, . . . a being superior to time and place." To Johnson, thoroughly convinced that life ought to be viewed from the moralistic side, knowledge is valuable only when ideas are applied to life, and his philosophizing continually verges towards the dividing line between speculation and conduct. He rebukes those who, while "making the choice of life," "neglect to live"; those who, like Rasselas, pass "four months in resolving to lose no more time in idle resolves"; he inculcates employment as the best cure for sorrow; perseverance, courage, and honesty as essentials of character; and concludes that "all that virtue can afford is quictness of conscience and a steady prospect of a 
happier state; this may enable us to endure calamity with patience, but remember that patience must suppose pain."

This fundamental characteristic of Johnson's philosophy of life - the sense of the consolation offered to man in the midst of mystery and unhappiness by virtue, by knowledge, and by faith in a future existence - renders interesting a comparison of Rasselas and Candide. ${ }^{1}$ The two contes philosophiques were published almost simultaneously, ${ }^{2}$ and show striking points of similarity and of difference. Johnson's reverent manner, for instance, is opposed to Voltaire's habitual mockery; yet Johnson sometimes satirizes shams with savage irony, and

${ }^{1}$ First French edition, Candide ou l'optimisme, . . . 1759; first English edition, same year.

${ }^{2}$ Rasselas was written soon after January 23, 1759, and published in March or April of that year. Johnson was one of the first to observe the similarity between the two books. "I have heard Johnson say, that if they had not been published so closely one after the other that there was not time for imitation, it would have been in vain to deny that the scheme of that which came latest was taken from the other." Boswell, Life of Johnson, edited by G. B. Hill, Vol. I., p. 342. Hill's note, same page: "It should seem that Candide was published in the latter half of February, 1759 . . Rasselas was written before March 23; how much earlier cannot be known." 
Voltaire, underneath his mockery, has an honest reverence for the truth. Both are absolutely independent and fearless in facing intellectual or philosophic problems.

The themes of Rasselas and Candide are strikingly similar. In this enigmatical world, says Voltaire, which is full of unhappiness due to misfortune and crime, optimism is false and futile. Candide spends his sheltered youth in a castle which he is taught to believe blindly is the most magnificent of all castles in the best of all possible worlds, - an environment of ideas as artificial as the Happy Valley is for Rasselas, and affording an equally sharp contrast to the real life outside. For the Happy Valley, if we look for the meaning of Johnson's allegory, signifies the environment, whether inherited or self-made, of the extreme optimist.

Rasselas has the optimistic temperament, hopeful, charitable, saying confidently: "Surely happiness is somewhere to be found." The other inhabitants of the Happy Valley, who enter it voluntarily and can never leave it, may be likened to optimists like Dr. Pangloss, Candide's base and foolish tutor, whose blindness is the darker because self-imposed, - none so 
blind as those who will not see. Gradually the conviction is borne in upon Rasselas that every search for happiness is futile, and his efforts end in a "conclusion in which nothing is concluded." The disillusionment of Candide, less profound than that of Rasselas, is more bitter because based on intimate and vivid experiences of crime and horrors.

Rasselas is Voltairean not only in general theme but also in several specific ideas. Johnson treats with keen satire the philosopher who "looked round him with a placid air and enjoyed the consciousness of his own beneficence," after exhorting men to "live according to nature." Rasselas respectfully asked him to define his terms, whereupon he enlarged as follows: "To live according to nature is to act always with due regard to the fitness arising from the relations ... of cause and effects; to concur with the great ... scheme of universal felicity; to coöperate with the general disposition and tendency of the present system of things.' The prince found that this was one of the sages whom he should understand less as he heard him longer. He therefore bowed and was silent; and the philosopher, supposing him satisfied, 
and the rest vanquished, rose up and departed with the air of a man that had coöperated with the present system." The irony of Voltaire finds an echo in Imlac's words: "learning from the sailors the art of navigation, which I have never practised, and ... forming schemes for my conduct in different situations, in not one of which I have ever been placed." There is obvious satire too in the account of the eminent mechanist who discoursed learnedly upon the art of flying. But his flying machine refused to fly and he promptly dropped into the lake, from which "the prince drew him to land half dead with terror and vexation." 1 Johnson's "wise and happy man," who talks nobly about fortitude, but who is unable to sustain the loss of his daughter, resembles the philosopher in Voltaire's sketch, Les deux Consolés, who seeks to solace a lady's grief by eloquence and refuses to be similarly comforted upon the death of his son. Imlac's encomium upon the busy and cheerful monastic life has been compared with

${ }^{1}$ Cf. G. B. Hill's note, p. 165 of his edition of Rasselas, Oxford, 1887: "Johnson is content with giving the artist a ducking. Voltaire would have crippled him for life at the very least; most likely would have killed him on the spot." 
the close of Candide. There the hero meets a contentedly ignorant old man whose entire life is employed in cultivating his garden, and who thus escapes from ennui, vice, and want. Candide is profoundly impressed, and brushes aside the grandiloquence of Pangloss with the significant reply: "Cela est bien dit, . . . mais il faut cultiver notre jardin." This is Voltaire's last word in Candide, and, like Johnson's comment upon the return of Rasselas to Abyssinia, is " a conclusion in which nothing is concluded." Thus the similarity of incidents and ideas brings us back to the deeper analogy between the themes: the disillusionment of the optimist who has been brought up in unreality.

All this similarity is, however, counterbalanced by an utter dissimilarity of treatment. A consideration of Voltaire's artistic method throws Johnson's concept of an oriental tale into bolder relief, with the high lights on those elements that he considered of prime importance. Voltaire enjoyed telling the story for the sake of the 'story, and delighted in the means he took to make blind optimism ridiculous, wit and keen satire, vivid description and incident, clever characterization, - in short, an 
artistic use of the concrete. Candide has been called "the wittiest book of the eighteenth century," and wit is a characteristic as far removed as possible from the seriousness of Rasselas. To Johnson the story was a means to an end, - a frame necessary to hold together and enhance the thought, - hence the simpler the frame the better. In Candide the story is interpenetrated with the theme, but not borne down by it. Candide, like Rasselas, is searching for happiness; but unlike Johnson's hero, he desires not happiness in the abstract, - a philosophical possibility, - but pleasure in the concrete form of his mistress. He travels far and wide, in hopeful anticipation; but when he finds her at last, she is no longer fair or lovable, and his marriage with her is perfunctory and joyless, a concrete, Voltairean expression of the idea that happiness attained is often no happiness, but vanishes in one's grasp like the apples of dust.

The scenes of Voltaire's tale, moreover, are not laid in remote Abyssinia, but chiefly in Europe, with an excursion to "El Dorado" in the New World, an impossible and comfortable Utopia, the memory of which serves to embitter 
Candide's distress during his subsequent misfortunes. The Europe of the tale is clearly the Europe of Voltaire's own day: there are obvious allusions to contemporary events, such as the execution of the innocent English admiral Byng in 1757, an excellent opportunity for Voltaire's famous gibe at the English: "Dans ce pays-ci il est bon de tuer de temps en temps un amiral pour encourager les autres." The characters also are more individualized than in Rasselas, and scenes like the visit to the blasé Venetian senator Pococurante (Chap. XXV.) ${ }^{1}$ are brilliantly depicted. Throughout the entire story one definite incident follows another, good and bad, but never indifferent; until a general effect of rich complexity, of rapid movementnot unlike that of Gil Blas - is attained. In the last analysis what more striking contrast to this work of Voltaire, the consummate artist and keen satirist, than Rasselas, the profoundly philosophical tale of Johnson the moralist? Voltaire's keen wit and brilliant mockery is indeed exhilarating after the slow and ponder-

${ }^{1}$ For a sketch of this scene, cf. an essay on Indifferentism, by Bliss Perry in the Atlantic Monthly, Vol. XCII., p. 329 et seq. 
ous progress of Johnson's thought; but, on the other hand, after the atmosphere of turmoil, excitement, and repulsive crime in Candide, the clear and pure air of Rasselas affords a welcome relief. In the remote regions of Johnson's imaginary Abyssinia and Egypt, events are of minor importance; the quiet, even advance of speculation concerning truth is Jôhnson's chief interest. There is no emphasis on any incident

-that might distract the attention, - in fact the only noticeable events are the flight from the Happy Valley and the adventure of Pekuah. Neither is there any emphasis on description; the Happy Valley is depicted in the most general terms; it might be any valley anywhere. Similarly, in describing the Lady Pekuah in the Arab's tent, or Rasselas in Cairo, or the pyramids of Egypt, - in each case Johnson abstains from the concrete and prefers the general term. Again, as to time and place he is vague. His scene is laid far from contemporary Europe. "Rasselas was the fourth son of the mighty emperor, in whose dominions the Father of Waters begins his course, whose bounty ... scatters over half the world the harvests of Egypt." In fact Johnson's method of orien- 
talizing his tale was extremely simple. "Imlac in Rasselas," he says, "I spelt with a $c$ at the end, because it is less like English, which should always have the Saxon $k$ added to the c." 1 Eastern localities are only occasionally mentioned, and always in a thoroughly Johnsonian manner: "Agra, the capital of Indostan, the city in which the Great Mogul resides;" "Persia, where I saw many remains of ancient magnificence, and observed many new accommodations of life." But there is no local colour, even in the account of Imlac's journey with the caravan to the Red Sea, or of the Arab bandits who demanded ransom for the Lady Pekuah, or of the story-telling in the cool of the day. The language, clear and often simple, always dignified and powerful, sometimes pompous, is seldom orientalized by the introduction of figures such as "the frown of power," "the eye of wisdom," "the waves of violence," "the rocks of treachery." Unobstructed by

${ }^{1}$ Boswell's Life of Johnson, edited by G. B. Hill . . . Oxford, 1887, Vol. IV., p. 31. Cf. on "the Saxon $k$," Thomas R. Lounsbury, Confessions of a Spelling Reformer, Atlantic Monthly, May, 1907 (Vol. XCIX.), p. 627: "The Saxon $k$ was the lexicographer's personal contribution to the original English alphabet." 
imagery, it reflects Johnson's clear and serious thought. The Happy Valley, as a central concept, is as simple as the bridge in The Vision of Mirza; indeed, Johnson's treatment of imaginative elements in general is like Addison's. Rasselas, like Mirza, is so generalized as to be "Everyman," lacking the specific traits of a living individual and in so far resembling characters in other oricntal tales. Yet the earnestness and dignity of the author raise Rasselas above the average oriental tale. Both theme and treatment compel attention, and like music, may be interpreted by each reader for himself. To a man of Johnson's temperament, habitually threatened by melancholy, the brighter side of life was invisible; such facts as abiding joy, enduring content, true happiness, were beyond his field of vision. Consequently Rasselas shows only the shadows of the picture, and is, in so far, untrue to life as a whole. But the truth that Johnson saw, he faced unflinchingly and depicted powerfully, and by this truth, so depicted, Rasselas still lives. Emphasis on philosophizing rather than on narrative; creation of a setting faint in colour; intentional vagueness regarding character, time, and place, result 


\section{THE ORIENTAL TALE IN ENGLAND}

in a strong impression of remoteness. The Abyssinia and Cairo of Rasselas are far-away and shadowy places, in which shadowy people move; but the questions raised, the grief expressed, come home to whoever "hath kept watch o'er man's mortality," and, like Johnson, perplexed by

$$
\text { " the mystery, }
$$

... the heavy and the weary weight

Of all this unintelligible world,"

has taken refuge in "learning," "integrity," and "faith." These are the realities behind the shadows in Rasselas, - realities which gain from the vagueness and remoteness of setting a heightened effect of universality. 


\section{CHAPTER IV}

\section{THE SATIRIC GROUP}

IN France satire used the oriental tale seriously for the purpose of criticizing contemporary society, morals, and politics; but also turned its criticism against the oriental tale itself, which it travestied and parodied. These forms of satire we may term, respectively, social and literary, - the former, satire by means of the oriental tale; the latter, satire upon the oriental tale. Such social satire had appeared as far back as 1684 with the publication of L'Espion turc ${ }^{1}$ by Giovanni Paolo Marana. This pseudo-oriental translation catered to the. growing interest in the Orient, contributing an important element to the oriental vogue not actually inaugurated until the publication of the epoch-making Mille et une Nuits (1704-1717). The genre of pseudo-letters, founded - so far as we know - by Marana, was continued by Charles Rivière Dufresny in his Amusemens (sic)

${ }^{1}$ Cf. P. Martino, op. cit., p. 284. 
serieux et comiques (1699), ${ }^{1}$ culminated in the Lettres Persanes (1721) of Montesquieu, and was widely diffused by a score of imitators. ${ }^{2}$ A particularly light and humorous form of social satire is exemplified in Marmontel's prose tale, Soliman $I I$.

The literary satire referred to above was a natural reaction against current enthusiasm for the extravagance of the oriental tale. Count Hamilton led this reaction with his entertaining parodies on oriental stories and fairy tales; Caylus, Voltaire, and others followed. In general the satirizing tendency seems to have been about evenly divided between social and literary satire. The natural inclination of the French to satirize foibles of social life and weaknesses of the social structure is plainly visible. Equally

${ }^{1}$ Cf. T. Brown, Amusements, p. 163, post. P. Martino, op. cit. (p. 288, n. 3), gives 1705 as the date of the first edition of Dufresny. But D. Jouaust, in his Avertissement to Entretiens ou A musements sérieux et comiques par Rivière-Dufresny, Paris, 1869, affirms that this work, whence "Montesquieu a pris l'idée de son immortelle satire," appeared "pour la première fois en 1699," and was reprinted. Pétit de Julleville: Histoire de la langue et de la littérature française des origines à 1900, Paris, 1898, Tome V., . . . p. 596, also gives 1699 as the date of Dufresny's work.

${ }^{2}$ Cf. P. Martino, op. cit., p. 299. 
apparent is their acuteness in perceiving and criticizing faults of literary style. In England the emphasis was characteristically different and rested more on conduct, less on art. Numerous translations and imitations of $\mathrm{Ma}$ rana, Montesquieu, and others appeared; and in Goldsmith's Citizen of the World the genre of pseudo-letters reached its highest point of development in England. There were a few interesting translations of French tales in which literary and social satire were mingled, such as those by Voltaire; and a few translations of literary parodies by Caylus, Bougeant, and Hamilton. But, if we except Horace Walpole's trifling Hieroglyphic Tales, there was no original English parody. ${ }^{1}$

As in France, so in England the impetus and direction to this particular form of satire were first given by Marana. ${ }^{2}$ The main idea of his Espion Turc - the disguised Oriental observing and commenting on European society and politics in a series of letters home - was ap-

${ }^{1}$ Cf. The Story of Tquassaouw, p. 173, post.

2 The "Characters" (character-sketches) of the seventeenth century, both in France and in England, undoubtedly contributed to the pseudo-letters, and vice versa. Cf. e.g. pp. 183 and 239, n. 1, post. 
parently original with him and was immediately popular. The first English translation, by William Bradshaw, slightly edited by Robert Midgley, appeared 1687-1693.' ${ }^{1}$ The character of the eight small, dusty volumes of the English version is curious. An historical preface to Vol. I. is followed by a Letter to the Reader which, like Irving's account of the disappearance of Diedrich Knickerbocker, tells how the Turk vanished from his rooms leaving behind his roll of manuscript, and beseeches the Gentle Reader's respectful attention. The Letters form a rambling journal of gossip on current politics and satire on society. "We must not expect to find here in Paris the great Tranquility which is at Constantinople. The Town is so full of Coaches, of Horses and Waggons, that the Noise surpasses Imaginations. Thou wilt certainly find it strange that Men who are in Health ...

${ }^{1}$ This English version has been ascribed to Sir Roger Manley by his daughter, Mrs. Manley; but it is now "practically certain ... that the first volume of the Letters was composed, not by Manley, but by Marana; and it is at least very probable that the Italian was the author of the remainder of the work." J. M. Rigg in the Dictionary of National Biography, article "Robert Midgley" (1653-1723). For title of this English version, ef. App. B, I., No. 1, p. 267. 
should cause themselves to be drawn in an Engine with Four Wheels. ... The more moderate French, which do not approve of this luxury, say, That, in the Time of Henry III. there were but Three Coaches in Paris, whereof Two were the King's; But the Number is now so great, that they are not to be counted. I can tell thee no more of the Genius of the French; thou knowest it perfectly. There is in all their actions a Spirit very delicate and an Activity like that of Fire. It seems as if none but they knew the short Duration of man's life; they do every Thing with so much Haste, as if they had but one Day to live; If they go on Foot, they run; if they ride, they fly; and if they speak, they eat up half their Words. They love new Inventions passionately. ... They love Moneys, which they look upon as the first Matter, and second Cause of all Things; They well nigh adore it and that is the Original Sin of all Nations." 1 On all sorts of subjects the Spy makes all sorts of remarks, trivial and serious, stupid and interesting, never very profound.

${ }^{1}$ Letter VIII. The Eight Volumes of Letters Writ by a Turkish Spy ... translated ... into English ... London ... 1748, Vol. I. Quotations are from this edition, and are given in the original spelling, etc. 
He gives court gossip; sketches his call upon Cardinal Richelieu in obedience to the Cardinal's command; and recounts stories of Spanish cavaliers, Italian ladies; and Arab galley-slaves. In oriental colouring The Turkish Spy, especially in its earlier volumes, is more consistent than later imitations like, for example, Lyttelton's Persian Letters. The Spy's point of view seems remote; he speaks as a foreigner might speak of customs that appear to him different from those of his native country. "How often," he says (Vol. VI., p. 3), "have I been like to discover myself by pronouncing the sacred Bismillah, either when I sat down to eat, or ... began any other Action of Importance. ... When I met any of my acquaintance in the street, I was apt to forget that I had a hat on, and instead of putting off that, according to the Fashion of the Franks, I laid my hand in my Breast, and sometimes bow'd so low, that my Hat fell off. . . . If I had Occasion to address myself to a Person of Quality, I was ready to take up the Bottom of his Cloak, Gown, or Robe, and to kiss it in token of Reverence, as the Custom is in the East, when we salute the Grandees. Nay, sometimes I could not forbear 
falling on my Knee, or prostrate on the Ground before Cardinal Richlieu [sic]." The description (Vol. I., p. 107) of the fair Paradise of the faithful, clad in robes of "pleasing green," and receiving from the hands of God their recompense, is not unlike the conventional descriptions in the Adventures of Abdalla or the Persian Tales. Eastern proverbs and stories are quoted (Vol. I., pp. 119, 140), and Eastern or pseudo-Eastern forms of blessing; e.g. " $\mathrm{He}$ that is Lord of the East and the West, from whose Throne hang Millions of Stars in Chains of Gold, encrease thy Virtues and Blessings, and preserve thee from the Poison of ill Eyes and malicious Tongues, and bring thee to the Fields of Endless Light" (Vol. II., p. 28); or "He that is merciful and gracious, who hath separated the Brightness of the Day from the Obscurity of the Night, defend both thee and me from the malice of Whisperers, from the Enchantments of Wizards, and such as breathe thrice upon the Knot of the Triple Cord" (Vol. III., p. 47). By slight touches throughout the Letters, the author with more or less success keeps up the illusion. But "the chicf permanent interest of the once popular Letters is 
derived from the fact that they inaugurated a new species of literary composition. The similar idea of a description of England as if by a foreigner was suggested by Swift as a good and original one in the Journal to Stella, and was utilized by Ned Ward and by many successors, but Montesquieu's Lettres Persanes (1723) is the best classical example. Many subsequent writers, including Charles Lamb, have been under obligations to the Letters, etc." 1

${ }^{1} \mathrm{~J}$. M. Rigg, in the Dictionary of National Biography, article on "Robert Midgley" (1653-1723). The date, 1723, for Montesquieu's Lettres Persanes should read 1721. Mr. Rigg cites several volumes of Notes and Queries; but does not give Notes and Queries, 4th Series, VIII., November, 1871, p. 415, in which Arthur Bateman writes: "Who but remembers Elia's account of the first discovery of roast pig? . . . In the Turkish Spy (Vol. IV., book 1, letter 5) I read as follows: 'The historians say that the first inhabitants of the earth, for above two thousand years, lived altogether on the vegetable products, of which they offered the first fruits to God - it being esteemed an inexpiable wickedness to shed the blood of any animal, though it were in sacrifice, much more to eat of their flesh. To this end they relate the first slaughter of a bull to have been made at Athens ... and the bull being flea'd [sic], and fire laid on the altar, they all assisted at the new sacrifice. . . . In process of time a certain priest, in the midst of his bloody sacrifice, taking up a piece of the broiled flesh which had fallen from the altar on the ground, and 
Dufresny's influence as well as Marana's on the development of the genre of pseudo-letters is clearly visible. The Amusements Serious and Comical Calculated for the Meridian of London (1700), ${ }^{1}$ by Thomas Brown, is in part a verbal translation, in part a paraphrase of Dufresny's work, with the addition of graphic sketches of London scenes and characters in the manner of Defoe. Brown nowhere acknowledges his indebtedness, however. His Preface, or rather Dufresny's, of which his is practically a translation, defends the choice of the title, Amusements Serious and Comical, for the thoughts on life he is about to present; and avows his purpose of robbing neither the Ancients nor the Moderns of learned quotations with which to decorate his style. He will rather pillage all he gives his reader from "the Book of the World, which is very ancient and yet always new." Amusement II., The Voyage of the World, a free translation

burning his fingers therewith, suddenly clapped them to his mouth to mitigate the pain. But when he had once tasted the sweetness of the fat, he not only longed for more of it, but gave a picce to his assistant, and he to others, who, all pleased with the new-found dainties, fell to eating of flesh greedily; and hence this species of gluttony was taught to other mortals.' "

${ }^{1}$ Cf. App. B, I., No. 2, pp. 267, 268. 
of Dufresny's Amusement Second, Le Voiage du Monde, describes general impressions of life at court. Brown adds vivid pictures of individuals, e.g. the Character of the Antiquated Beau: "Observe that old starched Fop there; his Hat and Peruque continue to have as little Acquaintance together as they had in the year '65. You would take him for a Taylor by his Mein, but he is another sort of an Animal, I assure you, a Courtier, a Politician, the most unintelligible thing now in being," etc. ${ }^{1}$ Amusement III., London, is based on Dufresny's Amusement III., Paris. For the imaginary Siamese whom Dufresny conceives as a traveling companion, Brown substitutes an Indian. Brown's idea of the location of India seems as vague as that of a fifteenth-century explorer. He calls his companion, "my Indian" and "my friendly American," and on the next page makes him compare St. Paul's with the Chinese Wall and contrast the irreverent conduct of Englishmen in church with the devout worship by his countrymen of "the gods in the pagods."

${ }^{1}$ Quotations, in which the original spelling and capitalization are preserved, are taken from The Third Volume of the Works of Mr. Thomas Brown . . The Third Edition . . . London . . 1715(?). 
But the chief difference between Brown's work and Dufresny's is due to the clever way in which the English writer enriches the brief, generalized, mildly satirical comments of his French original by concrete sketches of street life, - frequently coarse, but always picturesque, - which recall the work of Defoe or Hogarth. For instance, Dufresny writes: "Je supose ${ }^{1}$ donc que mon Siamois tombe des nuës, et qu'il se trouve dans le milieu de cette Cité vaste et tumultueuse, où le repos et le silence on peine à regner pendant la nuit même. D'abord le cahos bruiant de la rüe Saint Honoré l'étourdit et l'épouvante; la tête lui tourne.

"Il voit une infinité de machines differentes que des hommes font mouvoir: les uns sont dessus, les autres dedans, les autres derriere; ceux-ci portent, ceux-la sont portez; l'un tire, l'autre pousse; l'un frape, l'autre crie; celui-ci s'enfuit, l'autre court aprés. Je demande à mon Siamois ce qu'il pense de ce spectacle. J'admire et je tremble, me repond-il; j'admire que dans un espace si etroit tant de machines et tant d'animaux, dont les mouvements sont opposez ou differens, soient ainsi agitez sans se ${ }^{1}$ Cf. p. 166, note 1, post. 
confondre; se démêler d'un tel embarras, c'est un chef-d'œuvre de l'adresse des François. . . . En voiant vôtre Paris, continuë ce Voiageur abstrait, je m'imagine voir un grand animal; les ruës sont autant de veines où le peuple circule: quelle vivacité que celle de la circulation de Paris! - Vous voiez, lui dis-je, cette circulation qui se fait dans le cœur de Paris; il s'en fait une encore plus petillante dans le sang des Parisiens; ils sont toujours agitez et toujours actifs, leurs actions se succedent avec tant de rapidité qu'ils commencent mille choses avant que d'en finir une, et en finissent milles autres avant que de les avoir commencées. Ils sont également incapables et d'attention et de patience; rien n'est plus prompt que l'effet de l'oüie et de la vûë, et cependant ils ne se donnent le tems ni d'entendre ni de voir." 1

Compare the corresponding but far livelier passage in Brown." "I will therefore suppose this Indian of mine dropt perpendicularly from

1 The above quotation, in which the original spelling, etc., are preserved, is from Entretiens ou Amusements sérieux et comiques par Rivière-Dufresny, D. Jouaust, Paris, 1869.

${ }^{2}$ Frequent coarseness of expression precludes quotation of the entire passage. 
the Clouds, and finds himself all on a sudden in the midst of this prodigious and noisy City, where Repose and Silence dare scarce shew their Heads in the darkest Night. At first dash the confused Clamours near Temple-Bar stun him, fright him and make him giddy.

"He sees an infinite number of different Machines, all in violent motion, some riding on the top, some within, others behind, and Jehu on the Coach-box, whirling some dignified Villain towards the Devil, who has got an Estate by cheating the Publick. He lolls at full Stretch within, and half-a-dozen brawny ... Footmen behind.

"In that dark Shop there, several Mysteries of Iniquity have scen Light; and its a Sign our Saviour's Example is little regarded, since the Money-changers are suffered to live so near the Temple. . . Here stands a Shop-keeper who has not Soul enough to wear a Beaver-Hat, with the Key of his Small-Beer in his Pocket; and not far from him a stingy Trader who has no Small-Beer to have a Key to. ... Some carry, others are carried; Make way there, says a gouty-legged Chairman... Make room there, says another Fellow driving a wheelbarrow 
of Nuts, that spoil the Lungs of the City Prentices. . . One draws, another drives. Stand up there, you blind Dog, says a Carman, will you have the Cart squeeze [you]? . . . One Tinker knocks, another bawls, Have you Brass-pot, Kettle, Skillet, or Frying-Pan to mend? Whilst another . . y yelps louder than Homer's Stentor, Two a groat and Four for sixpence Mackerel? ... Here a sooty Chimney-sweeper takes the Wall of a grave Alderman and a Broomman justle[s] the Parson of the Parish. ... Turn out there, you ... says a Bully with a Sword two Yards long jarring at his Heels, and throws him into the Kennel. By and by comes a Christening with a Reader screwing up his Mouth to deliver the Service alamode de Paris, and afterwards talk immoderately nice and dull with the Gossips . . . followed with . . . a . . Trumpeter calling in the Rabble to see a Calf with six Legs and a Topknot. There goes a Funeral with the Men of Rosemary after it, licking their Lips after their hits of White, Sack, and Claret in the House of Mourning, and the Sexton walking before, as big and bluff as a Beef-eater at a Coronation. Here's a Poet scampers for't as fast as his Legs will carry 
him, and at his heels a brace of Bandog Bailiffs, with open Mouths, ready to devour him and all the Nine Muses."

Then follows the story of a visit to a coffeehouse, to St. Paul's, to the shops in Cheapside, and to many other places. During the walk Brown's Indian makes the remark Dufresny puts into the mouth of his Siamese concerning the city as an "Animal" through whose veins the streets - life circulates. To the final sentence: "[The people] don't allow themselves time either to hear or to see," Brown adds, "but like Moles, work in the dark and undermine one another." The above quotations suggest better than any comments the way in which Brown utilized and enriched his source. He discussed the same topics: the playhouse, the promenades, gallantry, mar-. riage, and gaming-houses; and from Dufresny's Cercle Bourgeois developed The City Lady's Visiting-Day, which, despite Brown's characteristically coarse tone and biting satire, recalls some of Addison's essays. That Brown influenced Addison has, in fact, been suggested. ${ }^{1}$ The earlier

${ }^{2}$ George Saintsbury, $A$ Short History of English Literature. New York, London, 1905, p. 526: "The great 
writer certainly holds a significant place in the line of development of the pseudo-letter genre.

The work of Marana, Dufresny, and Brown was continued by Addison and Steele, the first notable English men of letters to utilize the oriental material as a vehicle for satire. In the case of the moralistic and philosophic groups of oriental tales they gave the initial impulse; in this instance, though they did not originate the satiric tendency, they did assist in popularizing it. As early as No. 50 of the Spectator (April 27, 1711), Addison handles similar material in his account of "the very odd observations by four [American] Indian kings" as set down in a manuscript left behind them. St. Paul's they imagined to have been wrought out of a huge misshapen rock. "It is probable that when this great work was begun, . . . many hundred years ago, there was some religion among this people; for they give it the name of a temple and have a tradition that it was designed for

essayist who immediately followed him [i.e. Brown], owed more to him than might be imagined, and in not a little of his work, especially in his Amusements, Serious and Comical, which attempt an early 'London from day to day, there is a vividness of manners which anticipates the best of the later novelists." 
men to pay their devotions in. . . . But ... I could not observe any circumstances of devotion in their behaviour. . . . Instead of paying their worship to the deity of the place; they were most of them bowing and courtesying to one another, and a considerable number of them fast asleep." "This island was very much infested with a monstrous kind of animals, in the shape of men, called whigs; . . . apt to knock us down for being kings. . . . (The tory) was as great a monster as the whig and would treat us ill for being foreigners." After ridiculing the wigs of Englishmen and the patches of English ladies, the observations close, and Addison draws the moral that we should not be so narrow as these Indians, who regard as ridiculous all customs unlike their own. Another essay in the Spectator, ${ }^{1}$ similarly modeled on The Turkish . Spy or the Amusements, is a letter to the King of Bantam from his ambassador in England, 1682, criticizing the empty compliments of English social and diplomatic circles, and giving clever pictures of London life. The pretended letter from the King of China to the Pope asking for a Christian wife ${ }^{2}$ ridicules fantastic "ori-

1 No. 557.

${ }^{2}$ Spectator, No. 545. 
ental" descriptions; the assumptions of "his majesty of Rome and his holiness of China"; and "the lady who shall have so much zeal as to undertake this pilgrimage, and be an empress for the sake of her religion."

Two other essays, not pseudo-letters, complete the slender number of satiric oriental tales used by Addison and Steele. In one, the story of the transmigrations of Pug, the monkey, satirizes the ape-like character of the beau supposed to be incarnate in Pug. ${ }^{1}$ In the other ${ }^{2}$ Will Honeycomb, apropos of "those dear, confounded creatures, women," suggests having a marriage-fair as they do, he says, in Persia, where homely women are endowed with the money paid for beauties. He questions which would be the stronger motive in Englishmen, love of money or love of beauty. The same essay contains a story of a merchant in a Chinese town after a Tartar victory. He buys a sack for a high price, discovers in it an old woman, and is about to throw her into the river, but relents when she promises wealth. She keeps her promise, and their married life is contented.

'Spectator, No. 343.

${ }^{2}$ Ibid, No. 511. 
In the later periodicals throughout the century the number of such tales is even smaller than in the Spectator. The World, No. 40, on the "Infelicities of Marriage owing to the Husband's not giving way to the Wife," contains a bald abridgment of the Story of King Ruzvanchad and the Princess Cheristany "from the first volume of the Persian Tales." The Story of the Dervise's Mirror ${ }^{1}$ has almost no oriental colouring and is used for social satire. The mirror has the power of reflecting what a person really is, what he wishes to be, and what he thinks he is. The Connoisseur, No. 21, contains the story of Tquassaouw and Knonmquaiha, "an Hottentot story," which has been well described as "an indecent parody of the oriental style," and is the only example of deliberate parody in all the eighteenth-century periodicals. As suggested elsewhere, ${ }^{2}$ English writers used the oriental tale, not so much for literary as for social satire, and expressed their disapproval of the genre by direct criticism in preference to parody.

After the social satire of Addison and of Steele, the next in point of time and the most notable is that of Montesquieu. His Lettres

${ }^{1}$ Mirror, No. $8 . \quad{ }^{2}$ p. 157, ante; and p. 230, post. 
Persanes appeared in 1721..$^{\text {The date of the }}$ first extant English translation, by Mr. Ozell, was 1730; of the third edition of Ozell's version, 1731; of an anonymous translation, sixth edition, 1776. Thus, from 1721 on past the middle of the century, the work was accessible to English readers, and made the figure of the observant, satirical European in oriental disguise, introduced by The Turkish Spy, almost as familiar in England as on the Continent. Les Lettres Persanes is unquestionably the most artistic example of the oriental pseudo-letter. Montesquieu's genius raised his work above the level of the casual and intermittent comments and external details found in The Turkish Spy and the court memoirs of the seventeenth century, to philosophic and organic criticism of life. His chief aim was to express his views on social customs, forms of government, and questions of religion and conduct; and as he published the book anonymously, he was enabled to write with great freedom. His secondary purpose

${ }^{1}$ Cf. L. Dangeau, Montesquieu, Bibliographie de ses auvres. Paris, 1874; A. Sorel, Montesquieu (In the Series, Great French Writers), tr. by G. Masson . . . London, 1887, p. 46. L. Vian, Histoire de Montesquieu . . . Paris, 1879, Chap. V. 
was to entertain, and to this purpose his genius cleverly adapted the oriental colouring. The two Persians visiting Paris, the serious Usbek and the younger and gayer Rica, and their various correspondents, are vivaciously, if slightly, sketched; the best parts of the book are the comments on European ideas and eustoms, but the slender thread of story is not without interest. As the author, in the Preliminary Reflections prefixed to the quarto edition, says: "There is nothing in the Persian Letters that has given readers so general a satisfaction as to find in them a sort of romance without having expected it." 1 The "sort of romance" relates the insubordination of Usbek's wives in his absence and culminates in the unfaithfulness of his favourite wife Roxane and the death of her lover. It is Roxane who writes to Usbek the concluding letter, informing him that she has taken poison, and reproaching him with bitter scorn.

The oriental colouring in the Letters is thin, and is often set aside by the author in his eager-

${ }^{2}$ Reprinted in Persian Letters, by M. de Montesquieu, translated from the French, in two volumes. ... The Sixth Edition ... Edinburgh, 1773. The following quotations are from this edition. 
ness to discuss general questions. Usbek and Rica write, it is true, of bashaws, brachmans, transmigrations; the Guebres, who worship the sun and talk ancient Persian; Haly and Zoroaster; imams, magi, and the Koran. Customs of the seraglio are frequently used as an excuse for extreme license in description. But the author, by taking nominally the Persian point of view and by contrasting Persian ways with European, satirizes the latter adroitly. Among the subjects discussed are the evils of despotism, the value of a mild government and of a just administration of laws, the greediness of clergy, the fallibility and conceit of the French Academy, the caprices of fashion, the vanity of authors and of women. Of Spanish literature Rica writes: "You may meet with wit and good sense among the Spaniards, but look for neither in their books. View but one of their libraries, romances on this side, and school divines on the other; you would say that they had been made... by some secret enemy to human reason. The only good one of all their books, is that which was wrote to show the ridiculousness of all the others" (Letter LXXVIII.). Sometimes the criticism is em- 
bodied in clever character-sketches, like those of the would-be wits (Letters LIV., LXXXII.); the newsmongers or Quidnunes (Letter CXXX.); ${ }^{1}$ and the men of fashion (Letter LXXXVIII.). In Letter LXXII. Rica describes "a man who was highly pleased with himself." "He had decided, in a quarter of an hour, three questions in morality, four historical problems, and five points in natural philosophy. I never saw so universal a decider; his mind was never suspended by the least doubt. We left the sciences; talked of the news of the times. He decided the news of the times. I was willing to catch him, and said to myself; I must get into my strong fort; I will take refuge in my own country; I talked to him of Persia; but I had scarce spoke four words to him, but he contradicted me twice, upon the authority of Tavernier and Chardin. Hah! said I to myself, what a man is this here? He will presently know all the streets in Ispahan better than myself; I soon determined what part to take: I was silent, I left him to talk; and he yet decides." The question put to Usbek whether happiness is

'Cf. John Gay's poem, The Quidnunkis, in Chalmers, English Poets, London, 1810, Vol. X., p. 503. 
attained by virtue or by self-indulgence is answered by the story of the Troglodites, an ancient Arabian people to whom selfishness brought adversity, and virtue prosperity. ${ }^{1}$ Other stories inserted, after the fashion of the pseudo-letter genre, are The History of Apheridon and Astarte; ${ }^{2}$ a so-called Greek myth; ${ }^{3}$ the story of the Persian Lady Anais; ${ }^{4}$ and the incident of the patient cured of insomnia by reading dull books of devotion. ${ }^{5}$ It is not surprising to read in the Preliminary Reflections: "So great a call was there for the Persian Letters, upon their first publication, that the booksellers exerted their utmost efforts to procure continuations of them. They pulled every author they met by the sleeve, and said, Sir, I must beg the favour of you to write me a collection of Persian Letters." o

The first English collection of pseudo-letters written in imitation of Montesquieu and his predecessors was the Persian Letters of Lord Lyttelton (1735). ${ }^{7}$ Although inferior to Les

${ }^{1}$ Letters XI.-XIV.

${ }^{3}$ Letter CXLII.

${ }^{2}$ Letter LXVII.

- Letter CXLIII.

${ }^{4}$ Letter CXLI.

- P. IV. of Persian Letters cited, p. 175 n., ante.

${ }^{7}$ Cf. App. B, I., No. 28, p. 277. 
Lettres Persanes in literary value, the book needs more comment here beeause it is an English work and is less well known, and also because it directly influenced Goldsmith's Citizen of the World. The Prefatory Letter asserts that these letters are translated from the Persian, acknowledges that they lack the "Eastern sublimity" of the original, and attempts to forestall the aceusation that the character of the Persian is fictitious. Many such counterfeits have appeared both in France and England, the author says, but this is genuine. His defense not only fails to convince the reader but confirms the opinion gained from various authorities on Lyttelton's life and from the book itself, that it is a pseudo-translation written in English by Lyttelton.

The letter-form is used with far less skill than in the Lettres Persanes. Selim the Persian at London is supposed to write all the seventyeight letters to his friend Mirza at Ispahan, and the letters have thus the monotony of a journal instead of the varied interest of letters by several people. Lyttelton makes a slight and ineffectual attempt to imitate the artistic qualities of the dramatic narrative which forms the 
framework of the Lettres Persanes, but the reader can with difficulty disentangle the fragments of plot. In Letter XXIII. Selim's friend Abdalla is introduced, but does not appear again until Letter XLII. He then intrusts his wife Zelis to Selim while he returns to the East to ransom his father from captivity. The thread of the story is lost again until Letter LXXVIII., which recounts Abdalla's adventures and his reunion with Zelis. ${ }^{1}$ Finally, in Letter LXXIX. Selim reveals to Mirza his hopeless love for Zelis and consequent determination to return to Persia. The oriental colouring is as slight as the narrative. The author occasionally remembers to refer to Persia, "the resplendent palace of our emperor," and the seraglio, or to use an oriental phrase. "Madam" (says Selim to the mother of an English girl whom he wishes to marry), "I have a garden at Ispahan, adorned with the finest flowers in the East: I have the Persian jasmine and the tulip of Candahar; but I have beheld an English lily more fair ... and far more sweet." 2 Occasionally, the in-

${ }^{1}$ Abdalla and Zoraide, or Filial and Paternal Love, carries the same story to this point and ends with $\mathrm{Ab}$ dalla's expression of gratitude to Selim. Cf. p. 72, ante.

${ }^{2}$ Letter XXII. Quotations are from the edition of 1774. 
congruity between the Persian and English points of view results in humour. Selim describes a card-party as a sight "very strange to a Persian;... tables ... round which were placed several sets of men and women; they seemed wonderfully intent upon some bits of painted paper . . . in their hands. I imagined at first that they were performing some magical ceremony, and that the figures... on ... the ... paper were a mystical talisman. What more confirmed me in this belief was the grimaces and distortions of their countenances, much like those of our magicians in the act of conjuring. But ... I was told they were at play, and that this was the favourite diversion of both sexes." 1 Again he writes of a visit to a suburban villa, elegant, but so cold that he thought "the great saloon" the family burying-place, and caught a cold, "which," as he said, "took away my voice in the very instant that I was going to complain of what he made me suffer" (Letter XXXII.).

But the author often forgets the Persian

${ }^{1}$ Letter V. Cf. P. Martino, op. cit., p. 289, where reference is made to a similar passage in Dufresny's Amusements. 
point of view; his thin disguise falls off and reveals the grave English gentleman seriously concerned over the shortcomings of English society and government. He uses the pseudoletter merely as a means to a definite satirical end. He comments freely upon the unhappy victims of injustice in the debtors' prison; upon the courts of law, parliament, the evils of parties, "the abuse of the thing called eloquence," the growth and value of the constitution, the faults of the educational system, the soporific effects of fashionable opera, and the immorality of society. $\mathrm{He}$ depicts various types of character. "There is a set of people in this country, whose activity is more useless than the idleness of a monk. They are like those troublesome dreams which often agitate and perplex us in our sleep, but leave no impression behind them when we wake. I have sent thee an epitaph made for one of those men of business, who ended his life and his labours not long ago; ... 'Here lies . . ., who lived threescore and ten years in a continual hurry. He had the honour of sitting in six parliaments, of being chairman in twenty-five committees, and of making three hundred and fifty speeches. . . . He left 
behind him memoirs of his own life, in five volumes in folio. Reader, if thou shouldst be moved to drop a tear for the loss of so considerable a Person, it will be a Singular favour to the deceased; for nobody else concerns himself about it, or remembers that such a man was ever born" (Letter XXV.). Other "Characters" are the good-natured country gentleman, the benevolent bishop, the virtuoso, the vain man, the true wit, and the rough country squire. The last is drawn with real vigour. The squire was vastly enjoying the bear- and bull-baiting; and when Selim and a Frenchman criticized the dreadful cruelty of the sport, he "cast a very sour look at both. . . . He was dressed in a short black wig, had his boots on, and held in his hand a long whip, which, when the fellow fought stoutly, he would crack very loudly by way of approbation, ... [and would say] 'Let me tell you that if more people came hither and fewer loitered in the drawing-room, it would not be worse for Old England" "(Letter III.).

One of the best letters ${ }^{1}$ bears a close resem-

${ }^{1}$ Letter LXVII. The words underlined are found in the parallel passage in Goldsmith. Other similarities are noticeable. 
blance to Letter XIV. in The Citizen of the World: "The other morning a friend . . . told me, with the air of one who brings an agreeable piece of news that there was a lady who most passionately desired the pleasure of my acquaintance, and had commissioned him to carry me to see her. I will not deny to thee, that my vanity was a little flattered with this message: I fancied she had seen me in some public place and had taken a liking to my person; not being able to comprehend what other motive could make her send for a man she was a stranger to, in so free and extraordinary a manner, I painted her in my own imagination very young, and very handsome, and set out with most pleasing expectations, to see the conquest I had made: but when I arrived at the place of assignation, I found a little old woman, very dirty, encircled by four or five strange fellows, one of whom had a paper in his hand, which he was reading to her with all the emphasis of an author." She greeted Selim "with great satisfaction," saying she had long been curious to know a Mahometan and to be initiated into all the mysteries of the Koran in order to perfect a system of theology she had herself contrived. 
"' Madam,' replied I, in great confusion, 'I did not come to England as a missionary.... But if a Persian tale would entertain you, I could tell you one that the Eastern ladies are mighty fond of.' 'A Persian Tale!' cried she, 'Really, sir, I am not used to be so affronted.' At these words she retired into her closet, with her whole train of metaphysicians; and left my friend and me to go away, as unworthy of any further communications with her." Another proof that Goldsmith borrowed from Lyttelton is the similarity of certain names and incidents in Goldsmith's story of the Chinese Philosopher's son and the beautiful captive ${ }^{1}$ to those in the tale of Abdalla in the Persian Letters. In both are to be found the heroine Zelis, the sudden appearance of the beautiful slave to the hero, her account of her master's partiality, her flight with the hero, the separation and final reunion of hero and heroine. In putting in such a story Goldsmith followed the traditional lines of the genre and, as usual, improved upon the crude method of Lyttelton, exemplified in the utterly extraneous, coarse, and inartistic tales of Ludovico and Honoria, ${ }^{2}$ and of Acasto and Sep${ }^{1}$ Cf. pp. 71 and 180, n. 1, ante; and 197, post. ${ }^{2}$ Letter VI. 
timius, ${ }^{1}$ apparently of Italian or Spanish origin. Not until almost the last Letter does Lyttelton introduce the love of Selim for Zelis, - a belated attempt to enliven the tedium by some human interest. The slight sketches of English life break the monotony occasionally, but are not enough to redeem the dullness of the book as a whole. The satire is such as might be expected from a man who has been called amiable, ignorant of the world, "a poor practical politician," and "a gentleman of Elegant Taste in Poetry and Polite Literature." His chief claim to remembrance lies in the fact that he influenced Goldsmith. ${ }^{2}$

${ }^{1}$ Letter XXXI.

' Cf. in regard to Lyttelton (a) The Persian strip'd of his disguise . . . Dublin, 1735, a small pamphlet of twenty-three pages attacking Lyttelton's "late libel intitled Letters from a Persian in England to his friend in Ispahan."

(b) The Persian Letters continued, London, 1736, third edition, "erroneously ascribed to Lord Lyttelton." (Dictionary of National Biography.)

(c) Edward Moore's poem in defense of Lord Lyttelton, The Trial of Selim the Persian for divers high crimes and misdemeanours. (Chalmers: English Poets, London, 1810, Vol. XIV., p. 202.)

(d) The Court Secret a Melancholy Truth, now first translated from the original Arabic by an Adept in the Oriental Tongues, London, 1742, an anonymous work ascribed to Lord Lyttelton, but not included in the third edition of his works. 
The English pseudo-letters, aside from Lyttelton's Persian Letters and Goldsmith's Citizen of the World, are comparatively insignificant. Among them the most popular was Horace Walpole's Letter from $\mathrm{Xo}-\mathrm{Ho},{ }^{1}$ which was written May 12, 1757, and went through five editions in a fortnight. It is a brief, witty satire, aimed chiefly at the injustice of the system of political rewards and punishments, as exemplified in Admiral Byng's recent execution. There are a few good hits at social amusements, at the English weather, and at foibles of the English character in general. The oriental disguise is extremely thin, but is cleverly used to point the satire. For instance, Xo-Ho says: "I thought when a nation was engaged in a great war with a superior power, that they must have council [sic]. I was deceived; reason in China is not reason in England . . . my friend Lien Chi, I tell thee things as they are; I pretend not to account for the conduct of Englishmen; I told thee before, they are incomprehensible." Xo-Ho refers to "our august emperor," and swears by

${ }^{1}$ A Letter from Xo-Ho, a Chinese Philosopher at London, to his friend Lien Chi at Peling, in Works of Horatio Walpole, Earl of Orford, London, 1798, Vol. I., p. 205. 
"Cong Fu-tsee," but the mask does not conceal Walpole's supercilious smile. As a link in the development of pseudo-letters in England, $\mathrm{Xo}-\mathrm{Ho}$ is especially interesting, being in all probability one of the sources of Goldsmith's Chinese Philosopher.

The Citizen of the World is a good illustration . of the tribute paid by Dr. Johnson to Goldsmith: "Nullum quod tetigit non ornavit."

First printed in the form of bi-weekly letters in Newbery's Public Ledger, beginning January 24, 1760 , the book was immediately popular, and was published in 1762 under the title The Citizen of the World, ${ }^{1}$ or Letters from a Chinese Philosopher residing in London to his friends in the East. Numerous editions followed. From what source Goldsmith caught the phrase "Citizen of the World" is unknown. ${ }^{2}$ He may have taken it

${ }^{1}$ Cf. The Citizen of the World, edited by A. Dobson, 2 vols., London, 1893 . Introduction, pp. xi, xii.

${ }^{2}$ The earliest use of the phrase "citizen of the world" in English is believed to be in "England's Path to Wealth and Honour," by Puckle, 1700. In that work is found "An honest man is a citizen of the world. Gain equalizeth all places to me." Cf. Socrates (Plutarch: De Exilio, V.), "I am a citizen not of Athens or of Greece, but of the world;" E. Edwards: Words, Facts, and Phrases, London, 1882, pp. 117, 118; also Dante, 
from a French book which had appeared only a few years before, Le Cosmopolite (1750), by Fougeret de Monbron, and which had been reprinted in 1752 under the title Le Citoyen $d u$ Monde." Byron called it "an amusing little volume full of French flippancy," and drew from it a quotation ${ }^{2}$ which he prefixed to Childe Harold's Pilgrimage. Among Goldsmith's other sources are, of course, Montesquieu and Marana,

"My country is the whole world," De vulg. eloq. lib. 1, cap. 6, quoted by Burckhardt: Civilization of the Renaissance . . . tr. Middlemore . . 1904, pp. 132, 133, and note.

${ }^{1}$ Cf. Nouvelle Biographie Générale . . . sous la Direction de M. le Dr. Hoefer . . Paris, Firmin Didot Frères, Fils et Cie, Editeurs . . . 1865, Tome 35; article on "Monbron," which mentions Le Cosmopolite, 1750, and adds: "Il y a des exemplaires, avec la date de 1752, qui portent le titre: 'Le Citoyen du monde.'” E.H.Coleridge, Works of Lord Byron, London, New York, 1901, Vol. II. (Childe Harold, title-page), gives 1753 instead of 1752; and T. Moore, Works of Lord Byron, London, 1832, Vol. VIII., gives 1798.

2 " $L$ 'univers est une espèce de livre, dont on n'a lu que la première page quand on n'a vu que son pays. J'en ai feuilleté un assez grand nombre, que j'ai trouvé également mauvaises. Cet examen ne m'a point été infructueux. Je haissais ma patrie. Toutes les impertinences de peuples divers, parmi lesquels j'ai vécu, m'ont réconcilié avec elle. Quand je n'aurais tiré d'autre bénéfice de mes voyages que cclui-là, je n'en regretterais ni les frais ni les fatigues." 
possibly also Dufresny. The name Fum-Hoam he probably drew from the Chinese Tales. It is not unlikely that he knew the recent translation of Hau Kiou Chooan, ${ }^{1}$ by Wilkinson. He undoubtedly utilized Lyttelton's Persian Letters.

Like its predecessors, The Citizen of the World is a series of letters written ostensibly by an Oriental describing and satirizing the manners and customs of Europe by sharp contrast with the real or imaginary customs of his native land. Previous pseudo-letters had been interspersed, like the Addisonian periodicals, with episodical stories and character sketches, and The Citizen of the World elaborated both these lines of decoration. The most famous sketches are those of the "Man in Black," "Beau Tibbs," and the "Wooden-legged Soldier." But to the student of oriental fiction the chief interest of these Letters lies in the ease and facility with which Goldsmith handles his oriental material. Instead of attempting a cumbersome description of the Chinese Philosopher, Lien Chi Altangi, the first letter gives brief credentials as to his

${ }^{1}$ Hau Kiou Chooan; or the pleasing History, a translation [by J. Wilkinson] from the Chinese . . . [edited by T. Percy], London, 1761. Cf. App. B, II., No. 28, pp. 299,300 . 
honesty and respectability in a way that would surely appeal to the English public. His friend Fum-Hoam is a shadowy figure, just distinct enough to be a reeeptive correspondent. A touch of romanee is given by the frequent mention of Lien Chi's longing for home and the improbable but interesting love story of his son. The heroine, a beautiful slave, proves to be the nieee of the Man in Black, Lien Chi's best friend in London. The character of the Chinese Philosopher is purposely vague; the eomments on London life are Goldsmith's own. Every now and then he remembers to hold the mask before his face and to drop a sudden remark in charaeter, and the result is a humorous ineongruity. The pieture of London streets where "a great lazy puddle moves muddily along" is more vivid by eontrast to Lien Chi's memory of the golden streets of Nankin. ${ }^{1}$ Ideals of

${ }^{1}$ Cf. Letters from a Chinese Official, being an Eastern View of Western Civilization by G. Lowes Dickinson. New York, McClure, Phillips \& Co., MCMIII. Mr. Dickinson's book is an exceedingly interesting and timely criticism of Western civilization, and an instance of the vitality of the pseudo-letter genre, when the author has something to say. Cf. Mr. William Jennings Bryan's reply: Letters to a Chinese Official, being a Western View of Eastern Civilization. New York, McClure, Phillips \& Co., MCMVI. 
feminine beauty are all the more acutely and quizzically described by praising absolutely opposite Chinese standards. The justice of literary patronage in China is contrasted with the bribery and falsity of the English custom. Absurd English fashions in dress and household decoration, cruelty to animals, and inconsistent funeral rites are freely criticized. Goldsmith employs effectively the indirect method of the satirist who condemns one custom by praising its opposite. He seeks to give verisimilitude by quotations from Confucius, "the Arabian language," "Ambulaachamed the Arabian poet," and "a South American Ode." In the halfserious, half-humorous Preface Goldsmith tells us that "the metaphors and allusions are all drawn from the East. This formality our author [i.e. Lien Chi] carefully preserves. Many of their favourite tenets in morals are illustrated. The Chinese are grave and sententious; so is he. But in one particular the resemblance is peculiarly striking; the Chinese are often dull, and so is he. Nor has my assistance been wanting. We are told in an old romance of a certain knight-errant and his horse who contracted an intimate friendship. 
The horse most usually bore the knight, but, in cases of extraordinary despatch, the knight returned the favour, and carried his horse. Thus, in the intimacy between my author and me, he has usually given me a lift of his Eastern sublimity, and I have sometimes given him a return of my colloquial ease." 1 Usually Goldsmith begins a Letter with an oriental metaphor and soon drops into plain English. Sometimes his philosopher remembers to draw the letter to a close with a figure of speech. Letter II. begins: "Friend of my Heart, May the wings of peace rest upon thy dwelling." In the same letter the ship's progress is compared to the swiftness of an arrow from a Tartar bow. The goddess of Poverty is likened to a veiled Eastern bride supposed to be beautiful, but hideous when the veil is drawn. Vauxhall Gardens look to Lien Chi like the dreams of Mahomet's paradise. But Goldsmith's sense of humour and instinct of artistic restraint show him the absurdities of the pseudo-oriental style, and lead him to use such figures sparingly.

${ }^{1}$ Quotations are from The Citizen of the World, by Oliver Goldsmith, edited by Austin Dobson, London, 1893, 2 vols. 
The tales inserted in the Citizen of the World reveal a similar mastery of material. The majority are stories with a moral or satirical import and exemplify some general proposition. The insincerity and the brevity of effusive affection are amusingly illustrated by a variant of the Matron of Ephesus: the story of Choang the fondest husband and Hansi the most endearing wife (Letter XVIII.). ${ }^{1}$ The virtue of benevolence is set forth in the tale of the good king Hamti's triumphal procession, made up of the poor whose sufferings he had relieved (Letter XXIII.). The Rise and Decline of the Kingdom of Lao (Letter XXV.) is a moralistic tale concerning political evils, and is modeled apparently on the History of the Troglodites in Montesquieu or Lyttelton. False politeness is ridiculed, first directly, and then indirectly, by two amusing letters from the English lady Belinda and the Chinese lady Yaoua (Letter XXXIX.). Each deseribes an absurdly eeremonious eall which

${ }^{1}$ Cf. note on this Letter in Dobson's edition of The Citizen of the World (op. cit., p. 182, n.); W. Seele: Voltaire's Zadig (op. cit., p. 128); and K. Campbell: The Seven Sages of Rome . . Boston, 1907, Introduction, pp. ci-cviii, which gives seventy-six derivates and analogues of the story known as Vidua, of which The Matron of Ephesus is the most famous version. 
her suitor makes upon her father. The folly of avarice is taught by the story of Whang the miller, - a tale not unlike the familiar one of the woman who killed the goose that laid the golden egg (Letter LXX.). Injustice thwarted by quick wit is illustrated in the conclusion of the story of the clever prime minister (Letter CI.). ${ }^{1}$ Unjustly accused of misgovernment, he asked to be banished to a desolate village. His queen granted the request, but could find no such village. Hence she realized the universal prosperity of the country under her vizier's rule, and withdrew the unjust accusation. Several Eastern apologues are also used to illustrate some generalization. The fable of the elephant who prayed to be as wise as man, suffered discontent, and was happy only when restored to his former state of ignorance, exemplifies "the misery of a being endowed with sentiments above its capacity of fruition" (Letter LXXXII.) ; ${ }^{2}$ A Chinese fable, . . Five animals at a meal, sets forth the rapacity of lawyers (Letter XCVIII.); and An Eastern

1 Possibly suggested by Addison's tale, Spectator, No. 512.

${ }^{2}$ Drawn from "the fables of Locman the Indian moralist." 
Apologue of the Genius of Love, illustrates feminine insincerity and "false idolatry" (Letter CXIV.). Similar to this apologue is the author's dream of the Glass of Lao (Letter XLVI.), which reflects the true character of all the ladies who look into it. All prove to be faulty except one. Before her face the mirror remains fair, - because she has been "deaf, dumb, and a fool from the cradle." Two allegories in the manner of Addison and Johnson occur, one of Gardens of Vice and Virtue (Letter XXXI.) ${ }^{\mathbf{1}}$; the other, of the Valley of Ignorance, said by Goldsmith to be drawn from the Zend-Avesta, but resembling the Happy Valley of Rasselas (Letter XXXVII.). In addition to these more or less humorous short stories with a moralizing turn, there is one clever parody in Hamilton's style, of the fairy stories and oriental tales: the story of Prince Bonbenin bonbobbin

${ }^{1}$ Cf. Sir William Chambers's Dissertation on Oriental Gardening ... London, 1772; and Dobson's edition (1893) of The Citizen of the World, Vol. I., n. to p. 52, 1. 4, in which the editor refers to $A n$ Heroic Epistle by William Mason, ridiculing Chambers's Dissertation. Cf. also the satire in verse, Kien Long, a Chinese Imperial eclogue translated from a curious Oriental manuscript and inscribed to the author of An Heroic Epistle to Sir William Chambers, London, 1775. 
bonbobbinet and the white mouse with the green eyes; and one longer romantic narrative: the love and adventures of the Chinese Philosopher's Son and the beautiful Zelis (beginning in Letter VI.). ${ }^{1}$ Several tales of travel are found in the account of the Philosopher's journcy to Europe through countries "where Nature sports in primeval rudeness." In general, Goldsmith's use of tales and fables is similar to Addison's and Johnson's. His purpose is to say something serious under the guise of entertainment, to instruct as well as to amuse. In the mouth of his Chinese Philosopher the half-serious, halfhumorous criticism gains poignancy. ${ }^{2}$

The concept of this central character stimulated Goldsmith's quizzical common sense and keen appreciation of that incongruity which is the soul of humour; and also afforded an op-

${ }^{1}$ Cf. pp. $71 ; 180$ n. $1 ; 185$; and 191, ante.

2 "Goldsmith remembered a quotation from Voltaire made by himself in The Monthly Review for August, 1757: 'The success of the Persian Letters arose from the delicacy of their satire. That satire which, in the mouth of an Asiatie, is poignant, would lose all its force when coming from an European.'" Editor's Prefatory Note to The Citizen of the World in Vol. II., p. 86, Works of Oliver Goldsmith, edited by Peter Cunningham, F.S.A., in four volumes, New York . . 1881. 
portunity to express his democratic sympathies, - his benevolence towards all men, Chinese and English, far and near. This is the more noticeable in contrast with the attitude of polite society towards the East. The Chinese Philosopher is not unduly puffed up by his reception. "The same earnestness," he writes, "which excites them to see a Chinese, would have made them equally proud of a visit from a rhinoceros." The amusing scene (Letter XIV.) - already alluded to (p. 184) - describing Lien Chi's visit to the old lady, ridicules the current fad for grotesque Chinese bric-a-brac. "She took me through several rooms, all furnished, she told me, in the Chinese manner; sprawling dragons, squatting pagodas, and clumsy mandarins were stuck upon every shelf; in turning round one must have used caution not to demolish a part of the precarious furniture. In a house like this, thought I, one must live continually upon the watch; the inhabitant must resemble a knight in an enchanted castle, who expects to meet an adventure at every turning."

In general, the oriental decorations of the book are quite external. Yet the repeated reference to what the author imagines, or pre- 
tends to imagine, is the Chinese attitude of mind or turn of phrase, adds to The Citizen of the World a distinct and admirable element of humour. The book may justly be regarded as one of the best English oriental tales of the period.

Of the numerous French imitations of Marana and Montesquieu only a few of any importance were translated into English, for instance, the Chinese Letters $(1741)^{1}$ of D'Argens, and the Letters of a Peruvian Princess (1748), ${ }^{2}$ by Mme. F. Huguet de Graffigny.

A few other comparatively unimportant satires similar to the pseudo-letters may be mentioned briefly. As early as 1705 appeared The Consolidator, or Memoirs of sundry transactions from the World in the Moon. Translated from the Lunar Language By the Author of the True-Born Englishman. ${ }^{3}$ In this prose satire Defoe imagines the author of these Memoirs journeying from China to the Moon, in a remarkable, feathered flying-machine called the "Consolidator," and eriticizing the state of European society, polities, and letters by compari-

$$
\begin{aligned}
& { }^{1} \text { Cf. App. B, I., No. } 31, \text { p. } 277 . \\
& { }^{2} \text { Cf. App. B, I., No. 38, p. } 278 . \\
& { }^{3} \text { Cf. App. B, I., No. 5, pp. } 269,270 .
\end{aligned}
$$


son and contrast with Lunar and with Chinese conditions. Defoe's Tour through England, (1724-1726), though not satire, is connected with the genre of pseudo-letters in being written as if by a foreigner. In 1730 appeared Paul Chamberlain's translation of Mme. de Gomez's Persian Anecdotes, " a historical romance," purporting to be founded on actual history: "the singular events in the life of Ismael, Sophy of Persia," as related in the memoirs of D'Agout, De la Porte, and De la Forests, ambassadors of France at the Porte. The author protests vigorously against the charge that the romance is fictitious, but the character of the work seems to indicate that the charge is well founded. Upon an incoherent basis of historical fact is built a still more incoherent and rambling structure of fiction, - a panorama of stories concerning innumerable characters, more or less connected with the figures of the two friends, Ismael and Tor. Full of battles, insurrections, crimes, intrigues, - political and romantic, the book is commonplace and of little general value. It is of interest here only because the externals are oriental: the scenes are laid in ${ }^{1}$ Cf. App. B, I., No. 25, p. 276. 
the East; the proper names are Eastern, and there is a slight attempt to reproduce oriental customs. The popularity of the oriental disguise for various purposes is also shown by books like the Perseis or Secret Memoirs for a History of Persia. ${ }^{1}$ The preface to the French original asserts that the book is translated from an English work by an Englishman who made at Ispahan "un assez long séjour." A Key is affixed telling who the different characters are, e.g. Cha-Abbas I. is Louis XIV.; Cha-Sephi I., Louis XV. The history begins with the death of Cha-Abbas and continues through part of the reign of Cha-Sephi I. It is somewhat satirical, and contains more or less court gossip and criticism of various personages, but is stupid reading. The Conduct of Christians made the sport of Infidels, in a letter from a Turkish merchant at Amsterdam to the Grand Mufti at Constantinople on occasion of . . . the late scandalous quarrel among the clergy [by Kora Selym Oglan, pseud.], London, 1717, is a satirical pseudoletter. Milk for Babes, Meat for Strong Men, and Wine for Petitioners, being a Comical, Sarcastical, Theological Account of a late Election at

$$
{ }^{1} \text { Cf. App. B, I., No. 37, p. } 278 .
$$


Bagdad for Cailiff of that City. Faithfully Translated from the Arabick and Collated with the most Authentick Original Manuscripts By the Great, Learned and Most Ingenious Alexander the Coppersmith [W. Boles ?] . . . second edition, Cork, 1731, is a worthless political satire. The Oriental Chronicles of the Times; being the translation of a Chinese manuscript supposed to have been written by Confucius the Sage [a satirical account of events in 1784-1785 in defense of C. J. Fox], London (1785), is arranged in chapters and verses like the Old Testament and is a feeble effort. The Trial and execution of the Grand Mufti, From an ancient Horsleian manuscript found in the Cathedral of Rochester, London (1795?), is a satire on S. Horsley, Bishop of Rochester. A Brief and Merry History of Great Britain Containing an account of the religious customs, etc.,... of the people written originally in Arabick [by Ali Mohammed Hadji, pseud.]. Faithfully rendered into English by A. H. [A. Hillier], London (1710?), is a carping and coarse diatribe on English manners and life, with rare references to the superiority of Eastern ways, in the manner of the Turkish Spy, but far inferior. 
Smollett's political satire, the History and Adventures of an Atom (1769), ${ }^{1}$ is a pretended account of Japanese events as chronicled by a personified atom, who, by means of ridiculing the Japanese people, actually satirizes the English, e.g. in the description of the Council's going to sleep while discussing the defense of the nation from foreign invaders; or that of the councilor who endeavoured to make a speech and could only cackle. Smollett's introduction is picturesque. He imagines himself meeting "an old maid in black Bombazine," the administratrix of Nathaniel Peacock. She gives him Peacock's manuscript, which recounts how the atom appeared to Peacock and told him of its experiences in Japan. The book as a whole is of trifling value, occasionally humorous or bitterly sarcastic, and often coarse. ${ }^{2}$ Defoe's System of Magic $\left(\mathbf{1 7 2 6 ) ^ { 3 }}\right.$ contains the Story of Ali Abrahazen and the Devil and the Story of the Arabian Magician in Egypt." Finally,

${ }^{1}$ Cf. App. B, I., No. 58 (a), p. 285.

${ }^{2}$ Cf. The Works of Lord Byron . . . edited . . by E. H. Coleridge, London, New York, 1899, Pottry, Vol. II., p. 40, n.†.

${ }^{3}$ Cf. App. B, I., No. 5 (c), p. 270.

"In Novels and Miscellaneous Works of Daniel Defoe, Oxford, London, 1840, Vol. XII., pp. 101-135 and 154-181. 
The Bramine's Journal by Laurence Sterne, an unpublished manuscript now in the British Museum, is an interesting instance of the utilization of the oriental disguise. ${ }^{1}$

Enough has been said to illustrate the tendency in England to use oriental fiction for the purpose of social and political satire. In France such satire was frequently combined with parody of the rambling, complicated structure of many oriental tales, e.g. the frame-tale; and also with ridicule of the "oriental" style and diction. In England there was almost no parody of the narrative form of the oriental tale. Criticism tended rather to parody of the oriental diction and to frank mockery of the entire genre.

In one translation from the French the satire is purely social: Marmontel's Soliman $I I^{2}$

${ }^{1}$ Cf. App. A, pp. 257, 258, post. Swift's descriptive satirical poem, The Virtues of Sid Hamet the Magician's Rod, likewise uses oriental disguise.

${ }^{2}$ Cf. App. B, I., No. 54 (a), p. 284 . It became popular also in dramatic form, The Sultan or a Peep into the Seraglio, a Farce in two Acts, by Isaac Bickerstaffe, first acted 1775; printed, 1784, 1786, 1787. Another of Marmontel's works, - not a tale, but a comédie-ballet, called Zemire et Azor, formed the basis of a popular comic opera, Selima and Azor a Persian Tale, with music by Thomas Linley, Sr., London [1776]. It is a version of the story of Beauty and the Beast. 
(1764). This story, one of the cleverest of all Marmontel's Contes Moraux, recounts briefly the conquest of the great sultan by a pretty European slave, Roxalana, - a conquest so complete that her "little, turned-up nose" overthrows the laws of the empire. In the original preface the author writes: "I proposed to myself to display the folly of those who use authority to bring a woman to reason; and I chose for an example a sultan and his slave, as being two extremes of power and dependence." 1 When the story opens, Soliman, afflicted with ennui, demands in place of the "soft docility" 2 found in his Eastern women, the charms of "hearts nourished in the bosom of liberty." Three European slaves are therefore brought to his seraglio. The first, Elmira, is beautiful and affectionate; the second, Delia, has a charming voice; with each Soliman is content for a brief time. The third is the madcap Roxalana, who expostulates against the restraints of the seraglio with such vivacity that, despite her lack

'Quoted in Moral Tales by M. Marmontel. Translated from the French . . . New York, 1813, Vol. I.

${ }^{2}$ Quotations that follow are from Marmontel's Moral Tales Selected . . by George Saintsbury, London, 1895. 
of regular beauty, her piquant charm "disconcerts the gravity" of Soliman. "But the great, in his situation, have the resource of silence; and Soliman, not knowing how to answer her, fairly walked off, concealing his embarrassment under an air of majesty." At another time, he says: "But, Roxalana, do you forget who I am, and who you are?" - "Who you are and who I am? You are powerful, I am pretty; and so we are even." She continues to laugh at him, to do exactly as she pleases, and to entertain him with clever satire on European ways and Eastern customs. Finally, in order to impress her, he allows her to see him in all his glory, receiving ambassadors. But the effect on Roxalana is startling. "Get you gone out of my sight," she says to him. . . . "Is this your art of love? Glory and grandeur, the only good things . . . are reserved for you alone, and you would have me love you ! . . . If my lover had but a hut, I would share his hut with him and be content. He has a throne; I will share his throne or he is no lover of mine. If you think me unworthy to reign over the Turks, send me back to my own country where all pretty women are sovereigns." There is nothing for 
Soliman to do but to marry this extraordinary slave "in contempt of the laws of the sultans."

Among the translations from the French showing mingled social and literary satire, Voltaire's tales ${ }^{1}$ take precedence, notably The Black and the White; The White Bull; The Princess of Babylon; Memnon the Philosopher; and Bababec. The scenes of part of Voltaire's Travels of Scarmentado are laid in the East. The Princess of Babylon may be taken to illustrate Voltaire's method. The aged Belus, so the story begins, "thought himself the first man upon earth; for all his courtiers told him so, and his historians proved it." An oracle had ordained that the hand of his daughter, the surpassingly beautiful Formosanta, should be given only to the prince who could bend the bow of Nimrod and kill a ferocious lion. At a gorgeous tournament three. kings strove in vain. Suddenly a handsome youth appeared, riding on an unicorn and bearing a phœnix on his wrist. He bent the bow, saved the life of one of his rivals, sent a love poem to the princess, cut off the lion's head, gracefully drew its teeth, replaced them with magnificent diamonds, and gave the trophy to

$$
{ }^{1} \text { Cf. App. B, I., No. 39, pp. 279, } 281 .
$$


his phœnix. "Beautiful bird," said he, "carry this small homage and lay it at the feet of Formosanta." The great admiration and curiosity aroused, were increased by his sudden departure on receiving news of his father's mortal illness. After this opening scene, the rest of the story recounts the wanderings of the princess through almost all the known countries of Asia and Europe in search of the stranger, until they are finally reunited. The extravagant plot, incident, and diction of the earlier oriental tales are entertainingly parodied, and the travels of the princess and her lover give a good opportunity for keen satire on European customs and ideas. For instance, in one country the princess finds that birds also meet in a grove to worship God, and that they have some parrots that preach wonderfully well. Voltaire's satire strikes the hypocrisy of self-seeking clergy, the frivolity of "at least one hundred thousand" Parisians, and the wickedness of inquisitors who burned their victims "for the love of God." With satire in one hand and praise in the other, he commends reason in the Germans, good government among the English, and ideal government in Russia, which he calls the Cimmerians' land, 
probably meaning that ideal government is yet in Cimmerian darkness.

The Black and the White, a distinct and clever parody on oriental stories and fairy tales, recounts the passion of Rustan for a princess of Cashmire, who proves to be imaginary. $\mathrm{He}$ goes through marvelous adventures under the guidance of a good genius, "the White," and an evil genius, "the Black." But in the end he awakes out of an hour's sleep to find that he has dreamed all his adventures, including the death of his princess and his own mortal wound. "Take heart," said Topaz; "you never were at Kaboul; ... the princess cannot be dead, because she never was born; and you are in perfect health." The White Bull is a similar satire on oriental stories and fairy tales, and also on the miracles of the Old Testament and ignorant worship. The White Bull is the metamorphosed Nebuchadnezzar, who receives human form at the last and marries the princess of Egypt. Other characters are the Witch of Endor, Jonah's whale, Balaam's ass, and the serpent of Eden. Memnon the Philosopher is a satire on the vanity of attempting to be a perfect philosopher. Bababec is a sketch, mocking the folly 
of religious fanatics by describing the Fakir who becomes famous and thinks himself religious because he tortures himself with nails, in contrast with the wisdom of men who live useful, sensible lives. ${ }^{1} \quad$ The Travels of Scarmentado, a satire on persecution for conscience' sake, recounts one incident that recalls The Female Captive (cf. p. 50, ante). The hero hears a fair Circassian say "Alla, Illa, Alla" so tenderly that he thinks the words are expressions of love, and repeats them in his turn. He is accused of having become a Turk by saying those words, and escapes only with a fine. He flees to Persia. In his own words: "On my arrival at Ispahan, the people asked me whether I was for white or black mutton? I told them that it was a matter of indifference to me, provided it was tender. It must be observed that the Persian empire was at that time split into two factions, that of the white mutton and that of the black. The two parties imagined that I had made a jest of them both; so that I found myself engaged in a very troublesome affair at the gates

${ }^{1}$ R. Cambridge's poem, The Fakeer, a Tale, first published in 1756, is admittedly based on Voltaire. Chambers, English Poets, London, 1810, Vol. XVIII., p. 288. 
of the city, and it cost me a great number of sequins to get rid of the white and the black mutton."

In all these tales - even those that are apparently written for mere amusement-Voltaire's genius, masterly command of his material, and intense hatred of hypocrisy and injustice give to his satire a keen and penetrating quality which at once differentiates it from the comparatively care-free and superficial fun of Marmontel, Caylus, Bougeant, and Hamilton.

The three last named are the only other French satirists of any consequence whose works were translated into English in this period. The Oriental Tales $(1745)^{1}$ of Caylus is a good parody of the collections of oriental stories. The frame-tale, itself a satire upon the interminable method of story within story, is briefly as follows: Hudjadge, King of Persia, though gentle by nature, grows tyrannical from insomnia. He commands his jailer on pain of death to find a story-teller who can lull him to sleep. The jailer's beautiful daughter Moradbak offers herself somewhat as Scheherazade does in the Arabian Nights, and succeeds so admirably that the sultan sleeps in peace, re${ }^{1}$ Cf. App. B, I., No. 36, p. 278. 
gains his temper, and marries her. The first tale she tells is the appropriate History of Dakianos and the Seven Sleepers, and the king, "whose eyes had begun to close during the recital, ... came to himself when she had ceased speaking. 'I am satisfied,' said he; . . . 'I listened with some attention to the beginning of the history, but I did not interest myself much for thy little dog, and I was almost asleep with Jemlikha, as if I had been in his cavern; therefore, I know not much of what passed afterwards.' 'If your majesty has the least curiosity . . . I will begin ... again.' - 'No, no,' said the king, "I have enough for the first time.", After another tale "the sultan ... had appeared very wide awake all the time, though he might with reason have dropt asleep at some parts of it." Caylus succeeded only too well with his parody; most of his stories are decidedly soporific. A few familiar tales, such as the Seven Sleepers, and some entertaining stories like Jahia and Meimoune, break the otherwise uniform monotony. For oriental colouring we find the usual references to Mohametan legend: the mountain of Kaf, which surrounds the world and is composed of one emerald; the angel Isra- 
phil ; magical flights; genii and monsters; devout heroes; Solomon's ring; a treasure-cave accessible to an old dervish by means of his magic candlestick; and curious riddles like those in the Persian Tales. The descriptions are fantastic, extravagant, and occasionally coarse. Though the Oriental Tales is said to have been based upon genuine oriental manuscripts, it shows few traces of any such source, and is of value chiefly as exemplifying the tendency towards parody.

The Wonderful Travels of Prince Fan-Feredin, in the country of Arcadia, interspersed with observations historical, geographical, physical, critical, and moral. Translated from the original French of Guillaume Hyacinthe Bougeant, Northampton, n. d., ${ }^{1}$ is an entertaining parody on the heroic romances by name, e.g. Astrea, Palmerin, etc., and on the fairy tales, with occasional satirical remarks on the oriental tales as well.

One of the most popular of all the parodies and satires that followed so rapidly on the heels of the extravagant pseudo-translations in France was Fleur d'Epine, by Count Anthony Hamilton, the author of the Memoirs of Count Grammont. The English version, Thorn-Flower, ${ }^{1}$ Cf. App. B, I., No. 32, pp. 277, 278. 
$1760,{ }^{1}$ lost much of the wit and charm of Hamilton's style, and yet kept, of course, the humour of situation and narrative. How Hamilton began to write these tales, half earnest, half satirical, is quite in keeping with their light and entertaining character. "The conversation happened to turn in a company in which he was present on the Arabian Nights' Entertainments, which were just published; every one highly commended the book; many seemed to hint at the difficulty of writing that species of composition. 'Nothing can be more easy,' replied Count Hamilton, 'and as a proof of it I will venture to write a Circassian tale after the manner of the Arabian Nights' Entertainments on any subject which you can mention.' - 'Fiddlesticks!' (Tarare) replied the other. - 'You have hit it,' said Count Hamilton; 'and I promise you that I shall produce a tale in which Fiddlestick shall be the principal hero.' In a few days he finished this tale, which he called Fleur d'Epine. It was much read and admired in Paris." 2 The popularity is not sur-

1 Translated also as May-Flower, a Circassian Tale, second edition, Salisbury . . L London, 1796. Cf. App. B, I., No. 51, pp. 283, 284.

${ }^{2}$ Quoted in The Cabinet of Irish Literature . . by Charles A. Read. . . . London, 1880, Vol. I., p. 94, n. 2. 
prising, for the story is an exceedingly clever imitation - and parody - of its extravagant predecessors. The author pretends that it is one of the Arabian Nights' Entertainments, and in the introductory scene puts into the mouth of Dinarzade some capital mockery of the longwinded confusion of some of her sister Scheherazade's tales. Throughout, as in Hamilton's other tales, the interruptions and comments by the audience form comic interludes. Hamilton has caught the manner of the earlier stories admirably, and heightens it in ostensible seriousness just enough to bring it within the pale of ridicule. To say that his story is located far in the East is not sufficient. He proceeds to say exactly how far: "two thousand four hundred and fifty leagues from here." His princess, like her prototypes, is superlatively fair; but, moreover, her eyes are so brilliant that men die from her glance as if struck by lightning, and the artist who paints her portrait is obliged to wear smoked glasses. The introduction of the hero is farcical. $\mathrm{He}$ is a disguised prince, and when asked by the caliph what his name is, startles the whole court by replying, “' Tarare!' (Fiddlestick!) 'Tarare!' says the 
caliph; 'Tarare!' say all the counselors; 'Tarare!' says the Chancellor. 'I ask you,' says the caliph, 'what is your name?'-'I know it well, Sire,' he replies. - 'Well, then,' says the caliph. - 'Tarare!' says the other, making a bow. ... 'And why are you named Tarare?' - 'Because that is not my name.' 'And how so?' says the caliph. - 'It is because I have dropped my name to assume this one,' says he. - 'Nothing could be clearer,' says the caliph, 'and yet it would have taken me more than a month to find it out.'" The characterization is purposely colourless, as in the parodied tales. Yet there is occasionally a clever bit of character analysis, such as the account of May-Flower's sudden interest in her rival. In the use of magic, Hamilton's fancy runs riot side by side with his keen sense of the ridiculous; here his parody reaches its highest point. One of the tasks set the hero is the theft from an old witch of the "sounding mare." That remarkable creature carried a golden bell on every hair, and thus made "ravishing music." The ingenious Tarare silenced this music by filling each bell with a kind of glue, mounted the mare with May-Flower, and fled from the pursu- 
ing sorceress. The latter nearly succeeded in coming up with them, when at the last desperate moment, "Sonante," the mare, shook her left ear three times. The prince found in it a little stone, which he threw over his left shoulder. Instantly and just in time to save them there arose out of the ground a protecting wall, only sixty feet high, but so long that one could see neither the beginning nor the end. Other difficulties in the hero's path consisted of the animals that opposed his passage through the forest. "One would say that these accursed beasts knew his purpose, for in place of taking pains to come at him, they merely spread out to right and left; three hydras, ten rhinoceroses, and some half dozen of griffons, gazed upon his progress. He knew the rules of war well enough; so, after having examined the situation and their appearance, he saw their design, and since the sides were not equal, he had recourse to stratagem." One marvelous event is piled upon another until the author breaks out into an apostrophe: "Oh! how great a help are enchantments in the dénouement of an intrigue or end of a tale!"

Another of Count Hamilton's stories, Le 
Bélier, ${ }^{1}$ half parody, half imitation of the fairy tales, incidentally pokes fun at the oriental tales, too. The fair heroine, Alie, insane with love, imagines that she is Scheherazade in the Thousand and One Nights, and that she must at once tell a tale. In the midst of her soliloquy she falls asleep, to be awakened by her father, who is somewhat startled to have her address him as "Great Commander of the Faithful!" The Ram is an enchanted prince who tells a tale to his master, the giant, beginning abruptly: " After the white fox was wounded, the queen did not fail to visit him.' 'Friend Ram,' said the giant, interrrupting him, 'I do not understand that at all. If you would begin at the beginning, you would give me pleasure; these tales that begin in the middle only confuse ${ }^{2}$ my imagination.' - 'Very well,' said the Ram. 'I consent, against the usual custom, to put each event in its place; the beginning of my story shall be at the commencement of my recital."' Later, when the story-teller follows the conventional method in leaving some of his

${ }^{1}$ The Ram, in Select Tales. . . T Translated from the French ... London, 1760.

2 "Embrouiller." 
personages on a magic island at a critical juncture, the giant again objects, and forbids him to leave the island until he has quite finished their story. Of talismans, Hamilton says: "Great was the virtue of ancient talismans, and even greater the faith of those that believed in them." He describes extravagant emotions thus: "Joy, astonishment, and anxiety were simultaneously depicted on the face of the druid, though it is rather difficult to depict them all at once on the same face."

Les Quatre Facardins, ${ }^{1}$ the last in order of composition of Hamilton's tales, is the least interesting. As the author confesses, in his rhymed preface, one who like himself sets out jokingly to imitate and to make fun of such absurdities ends by becoming equally absurd. That is true of The Four Facardins. No oriental tale could be more extravagant in plot and incident. The various adventures of the four princes of the same name, Facardin, are so utterly tangled that the reader, like the giant in Le Bélier, feels as if his imagination were

${ }^{1}$ The Four Facardins, in Select Tales ... translated from the French, London, 1760. Cf. also M. G. Lewis: Romantic Tales, London, 1808. 
becoming "embrouilleee." It is not surprising that the author left the story unfinished. The frame-tale begins hopefully to recount how Prince Facardin of Trebizonde tells his adventures to Sultan Schariar, Scheherazade, and Dinarzade; but, after the other Facardins begin their own stories, the main thread would be hard to follow, were that necessary. Their various adventures include encounters with lions, enchanters, giants, and fair ladies, and are enlivened with fanciful descriptions, sometimes in questionable taste, - and occasional humour. On the whole The Four Facardins is not nearly so entertaining as Hamilton's other tales.

The only English writer who made a deliberate attempt to parody the structure of the oriental tales was Horace Walpole. His Hieroglyphic Tales (1785) ${ }^{1}$ are, as the postscript says, "mere whimsical trifles, written chiefly for private amusement; half a dozen copies only are printed." But even though a mere skit, the book is interesting as a straw to show which way the wind was blowing. The Preface is a rather clever satire on the pretentious, highly

$$
{ }^{1} \text { Cf. App. B, I., No. } 49 \text { (b), p. } 283 .
$$


moralistic, and would-be scholarly prefaces to oriental tales; and informs the reader that "the Hieroglyphic Tales were undoubtedly written a little before the creation of the world ... . and preserved by oral tradition in the mountains of Crampcraggi, an uninhabited island not yet discovered." The seven short stories which make up the book are somewhat similar to Hamilton's. The scene of the first, $A$ New Arabian Nights' Entertainment, is laid in the kingdom of Larbidel. "The other side of the mountain was inhabited by a nation of whom the Larbidellians knew no more than the French nobility do of Great Britain, which they think is an island that somehow or other may be approached by land." The other stories are also parodies: The King and his Three Daughters; The Dice-box; The Peach in Brandy, a Milesian. Tale; Mi Li, a Chinese Fairy Tale; and a Venetian Love-story of two black slaves who prove to be dogs.

Walpole's tone of supercilious mockery toward the oriental tales was typical of critical opinion generally between the middle of the century and the end of our period (c. 1786). Preluded by Pope's ridicule of Ambrose Philips as 
"The bard whom pilfer'd Pastorals renown, Who Turns a Persian Tale for half-a-crown,"

such criticism found its best expression in Goldsmith. The Citizen of the World (Letter XXXIII.) ridicules authors who attempt "to write in the true Eastern style, where nothing is required but sublimity." Lien Chi is amused to hear an English lady say: "Oh, for a history of Aboulfaouris [sic], the grand voyager, of genii, magicians, rocs, bags of bullets, giants, and enchanters, where all is great, obscure, magnificent, and unintelligible;" and even more amused when an author in the company rejoins: "I have written many a sheet of Eastern tale myself ... and I defy the severest critic to say but that I have stuck close to the true manner. I have compared a lady's chin to the snow upon the mountains of Bomek; a soldier's sword to the clouds that obscure the face of heaven. If riches are mentioned, I compare them to the flocks that graze the verdant Tefflis; if poverty, to the mists that veil the brow of mount Baku. I have used thee and thou upon all occasions, I have described fallen stars, and splitting mountains, not forgetting the little Houris who make a pretty figure in every de- 
scription. But you shall hear how I generally begin. 'Eben-ben-bolo, who was the son of Ban, was born on the foggy summits of Benderabassi. His beard was whiter than the feathers which veil the breast of the Penguin; his eyes were like the eyes of doves, when washed by the dews of the morning; his hair, which hung like the willow weeping over the glassy stream, was so beautiful that it seemed to reflect its own brightness; and his feet were as the feet of a wild deer, which fleeth to the tops of the mountains.' There, there, is the true Eastern taste for you; every advance made towards sense is only a deviation from sound. Eastern tales should always be sonorous, lofty, musical, and unmeaning."

Except for the Arabian Nights, many of the oriental tales that had appeared up to 1760 . 1761, when Goldsmith wrote, or even up to the date of Walpole's parody (1785), gave considerable provocation for such criticism. Indeed, to a certain extent, the vogue of these tales was another expression of the tendency more grotesquely manifested in the current craze, likewise ridiculed, for Chinese domestic architecture and house furnishings. "A few years ago," 
William Whitehead writes (World, No. 12, 1753), "everything was Gothic, now it is Chinese." In 1754 William Lloyd describes a country place decorated by "Chinese artists":-

"The trav'ler with amazement sees

A temple, Gothic or Chinese;

With many a bell and tawdry rag on, And crested with a wooden dragon." 1

The World, No. 117, ridicules the "applause so fondly given to Chinese decorations or to the barbarous productions of a Gothic genius which seems once more to threaten the ruin of ... [Greek] . . . simplicity . . . [which is so] . . . superior." The same essay describes a visit to Lady Fiddlefaddle's Chinese dressing-room. She had thrown aside her grandfather's fine Italian pictures for the sake of red dragons, "pagods," and ugly monsters. Just as "the Greek and Roman architecture are discarded for the novelties of China .... [so] Correggio is neglected for gothic designs . . . and the tinsel of a Burletta has more admirers than the gold of Shakespeare." 2 It may be, Warton goes on to

${ }^{1}$ Connoisseur, No. 135. Chalmers, English Poets, London, 1810, Vol. XV., p. 81.

${ }^{2}$ Warton, in Adventurer, No. 139. Cf. also World, Nos. 26, 38, 59, 65, 205; Rambler, 82; Adventurer, 109; 
say, that an attempt to improve this state of learning and taste will be thought "romantic . . and chimerical." The Connoisseur, No. 122 , ridicules the faults of a man of fashion who goes so far as to think the Bible to be "as romantic as the Alcoran." To a writer in the World, No. 70, one redeeming quality in the craze for oriental tales is the fact that some of them "contain useful morals and well-drawn pictures from common life." A later contributor to the same periodical, No. 121, writes to the editor: "Among the many visions related by your predecessors and contemporaries, the writers of periodical essays, I remember few but what have been in the oriental style." And he adds a sentence which may be taken as epitomizing the critical opinion of his contemporaries: "For my own part, I am neither Dervise nor Brachman, but a poet and a true Christian."

Connoisseur, 65, 73; Mirror, 17; Lounger, 79; and Sir William Chambers's Designs of Chinese Buildings, etc., London, 1757. 


\section{CHAPTER V}

\section{LITERARY ESTIMATE}

UPON a general survey of the four groups of oriental tales described in the preceding chapters, one is impressed by the exceedingly diversified nature of the collection, and - paradoxical though the statement may seem - by the presence of a sufficient number of common qualities to give the collection as a whole a distinctive character: it is "the oriental tale in England in the eighteenth century." In form this fiction includes within its wide range the frame-tale, in which stories - sometimes in letter-form - are inclosed; isolated apologues and other short tales used to point the moral of an Addisonian or Johnsonian essay; fantastic tales in which adventure is everything; tales equally fantastic but coloured by satire; 'and tales with the thinnest possible thread of plot to sustain the predominant satiric, moralistic, or philosophic purpose. The characterization is uniformly slight, and tends toward more or less abstract types. The scenc is laid in the Orient, 
from Egypt to China, or in Europe visited by Orientals; and is given a picturesque background of strange Eastern customs, sometimes enriched by allusions to religious or philosophical beliefs, often by lavish use of magic and enchantment. Oriental or pseudo-oriental nomenclature aids in producing the desired effect of remoteness. "The language is usually coloured by oriental phraseology, and is frequently - but not necessarily - figurative and inflated. As might be expected, the amount of local colour, the richness of detail, and the truth to oriental manners and places are greater as the stories approximate genuine Eastern fiction like the Arabian Nights. At the other end of the scale, in thoroughly Anglicized oriental tales, such as Rasselas and Nourjahad, the background is pale and shadowy, details are sparse, and references to Eastern places and customs are rare. But in all this fiction there is a distinctly exotic flavour, distilled through the medium of eighteenth-century ideas.

The general course of development of the genre in England followed the lines of the similar French movement, but with characteristically different emphasis. In France the move- 
ment - preluded by the pseudo-oriental satire, The Turkish Spy - was initiated by highly imaginative oriental translations contemporaneous with the fairy tales of Perrault. It was continued by imitations in which qualities from both oriental tales and fairy tales were blended, - notably extravagant invention and magic; by literary parodies aimed at form and style; and by social satires, ranging from comments on manners to philosophic criticism of life. Finally, the natural decline of the oriental tale as a genre, together with that of the fairy tale, was hastened by the weight of 'extreme license on the one hand and of moralistic didacticism on the other. In England, the Arabian Nights and its companions were warmly welcomed, but there was no sudden efflorescence of imaginative and fanciful fiction as there had been in France. English writers at first contented themselves, as far as imaginative tales were concerned, with translating from the French. It is worth noting that they did not translate the fairy tales of Perrault until 1729. ${ }^{1}$ The blending of the fairy tales with the oriental

${ }^{1}$ Cf. (a) The Blue Fairy Book . . . edited with an Introduction by Andrew Lang . . . [Large Paper], London, 1889. 
tales in France was one of the most striking characteristics of the movement, and the comparative lack of the fairy element in England limited, in so far, the initial scope of the English movement. But in France, after the first furore, no new kinds of purely imaginative oriental stories or fairy tales appcared; while in England, from time to time throughout the century, imaginative oriental tales were written, including realistic stories, a tragic romance, Charoba (translated from a seventeenth-century French version), and a tale of terror,

Introduction: "Though published in 1697, Perrault's Contes de ma Mère l'Oye do not seem to have been Englished till 1729. A version is advertised in a newspaper of that year, but no copy exists in the British Museum."

(b) English Fairy Tales, collected by Joseph Jacobs . . . third edition . . . New York, 1898, p. 229. Notes. "In the middle of the last century the genius of Charles Perrault eaptivated English and Scotch children.... Cinderella and Puss-in-Boots . . . ousted Childe Rowland, and Mr. Fox and Catskin. The superior elegance and clearness of the French tales replaced the rude vigour of the English ones. What Perrault began, the Grimms completed. Tom Tit Tot gave way to Rumpelstilzchen. . . The English Fairy Tale became a mélange confus of Perrault and the Grimms."

(c) The Countess D'Aulnoy's Tales of the Fairies was translated in 1707. 
Vathek. In both countries dramas, especially farces, were based on this fiction. ${ }^{1}$

Satire in France - as suggested above followed two lines of development: the social line inaugurated by Marana, and the literary or parodic, - a natural reaction from the extravagances of the imaginative tales. English satire in oriental guise was chiefly social, occasionally political, rarely parodic. The reaction against the enthusiasm with which the oriental tales had been greeted, was voiced not so much in actual parody as in direct ridicule or critical disapproval. Pope's friend, Bishop Atterbury, was not alone in thinking "the Arabian Tales" "so extravagant, monstrous, and disproportioned" that they "gave a judicious eye pain." 2 Pope's own gibe at the hack-writer who could "turn a Persian tale for half-a-crown" was echoed fifty years later by Goldsmith: "Mr.

${ }^{1}$ Cf. pp. 76, n. 2; 96, n. 1; and 204, n. 2, ante. Dramas based more or less on oriental history appeared from time to time, e.g. Hughes's Siege of Damascus (1720); D. Mallet's Mustapha (1739); Johnson's Irene (1749); Hodson's Zoraida (1780); A. Dow's Zingis, a Tragedy, new edition (1773); and translations of Voltaire's $M a-$ homet, Zara, and Orphan of China. Cf. Dr. Hoops, Present Problems (App. B, II., No. 33, p. 300).

${ }^{2}$ Works of A. Pope . . edited . . by . . Rev. W. L. Bowles, London, 1806, Vol. VIII., pp. 110, 112. 
Tibs [is] a very useful hand; he writes receipts for the bite of a mad dog and throws off an eastern tale to perfection." 1 What there was of parody was directed against the so-called oriental diction and phraseology, while in France parody was aimed chiefly at the narrative form and the extravagance of incident. On the whole, English satire had a narrower range and followed chiefly the line of light and cheerful humour best exemplified in The Citizen of the World. French satire, more pervasive and more penetrating, expressed - especially when touched by the genius of Voltaire and Montesquieu - something of the deep unrest of France in the eighteenth century, the era before the Revolution. Even the contes philosophiques are tinged with satire. The typical English writer of philosophic oriental tales, on the contrary, dwelt in an imaginary country of pure speculation, and entered the world of fact only for the purpose of moralizing.

The emphasis which in France was thrown upon satire fell in England upon philosophy and

${ }^{1}$ Citizen of the World . . . edited by A. Dobson . . . London, 1893, p. 121, note to p. 141, 1.25: "Mr. Tibs (is) a different person, by the way, from the inimitable little Beau." 
morals. From The Vision of Mirza to Rasselas; from Parnell's Hermit to Miss Edgeworth's Murad the Unlucky; throughout the entire period the two tendencies were steadily prominent. At the outset, Addison and Steele set the example of wresting the new imaginative oriental fiction just received from France out of its original shape into something more conformable to their sincere ideas of worthy literature. Dr. Johnson and many others, especially in the periodical essays, intensified this didactic tradition. In literary merit the philosophic tales take precedence over the moralistic, though the latter are far more numerous. Enough has been said in the preceding chapters to make clear the character of the two groups. The questions at present of greater importance in our discussion are the reasons why the genre in England followed the philosophic and moralistic tendencies and the other lines of development mentioned in the preceding paragraphs. How may we account for the presence and more or less general popularity of this fiction in England during the eighteenth century? Why were the imaginative tales so soon diverted to didactic purposes?

The environment into which the Arabian 
Nights and the Persian Tales came was that of an age which expressed itself most naturally in rationalistic prose and satiric verse. The moralizing tendency, characteristic also of the eighteenth century on the continent, has been called a fundamental instinct of the British character; and at that time was so powerful and widespread as to colour all English literature. Even Fielding did not escape, much less the writers of these Eastern stories. The environment proved stronger than the new organism. Too exotic to become easily acclimated, such tales were regarded as entertaining trifles, to be tolerated seriously only when utilized to point a moral. The moralizing tendency and the rationalistic mood were two barriers opposed to the free development of imaginative oriental fiction. A third obstacle was the deference shown to the canons of French classicism. All things French were welcomed, but only those sanctioned by Boileau found lasting and serious consideration; and the sober second thought of Augustan criticism was thus strengthened in its disdain of the oriental tale. Furthermore, a barrier existed in the insularity of English life and thought. Aside from her connection with 
France, England was surprisingly insular in the early eighteenth century. Literary England was confined, in large measure, to London alone, because of the practical difficulties of communicating with the country. Roads were bad, journeys difficult and perilous. Foreign travel was by no means so common as later in the century. The East was indeed the "Far East," chiefly used as a figure of speech for fabulous wealth or excessive tyranny. Usually the contrast was drawn in favour of England. Dyer, in his poem, The Fleece, even praises the happy English sheep in comparison with the less favoured sheep of other lands. Mohammedanism was regarded as an imposture and Buddhism was practically unknown. It was not until the victories of Clive in India and the era of expansion under the elder Pitt that England took any vital interest in the Orient, - an interest first expressed in literature by direct translations from oriental language in the last quarter of, the century. In the earlier decades, England, on the whole prosperous and peaceful under Walpole's long rule, was satisfied with her insularity; a feeling voiced by Shenstone in the poem entitled, Declining an invitation to visit 
foreign Countries, he takes Occasion to intimate the Advantages of his own. ${ }^{1}$

But, even had there been no such obstacles to overcome in the environment, a barrier to the free imaginative development of the oriental tale would have existed in the character of the first eighteenth-century translations of oriental fiction. They lacked too frequently not only the graphic detail, which in accounts of far distant lands fascinates the reader, but also the deeper elements of characterization that make the whole world kin and are the most potent means of breaking down superficial barriers between alien peoples. When Galland prepared his version of the Arabian Nights for European readers, he omitted not only the coarseness of the original, but also many of its interesting minutiæ, details which give to our later versions - Burton's and Payne's, for instance - the charm of good tales of travel, and produce in the reader the vivid sense of actually being in the picturesque Orient. The French and English successors of Galland followed him in this respect and fell short even of his achieve-

'Shenstone's Poems, in Chalmers, English Poets . . . London, 1810, Vol. XIII., p. 272. 
ment. Hardly any English writers until past the middle of the century knew or apparently cared to know the East well, either through travel or through books; hence the pale and colourless quality of their oriental fiction. ${ }^{1}$ Beckford was the first to introduce much picturesque detail, and in so doing anticipated the methods of Moore, Southey, Byron, and their successors.

The lack of vivid descriptions, however, was far less serious than the presence of alien elements without the saving grace of deep human interest. Unlike Gothic legend, Celtic poem, or English ballad, the oriental tale formed no intimate part of the national heritage. Something latent or sleeping in the nature of the English people was roused during this century by a sudden revival of interest in things their ancestors had loved and lived with; and Percy's Reliques, Walpole's Castle of Otranto, the Poems of Ossian, struck a responsive chord. But the oriental tale was alien; and incident, atmosphere, fancies, understood and liked by Eastern listeners, seemed too grotesque and incredible

${ }^{1}$ Dr. Johnson (Rambler, No. 122) commends Knolles's History of the Turks, but declares the subject foreign and uninteresting, a remote and barbarous nation "of which none desire to be informed." 
to make more than a limited appeal to untraveled English readers." They welcomed, rather, with characteristic heartiness the homely, realistic background of Defoe's stories. If the oriental tale had emphasized the more fundamental elements of human character - the passions of love, hate, ambition, revenge - in addition to the spirit of adventure and delight in the picturesque and the mysterious, then whatever was alien in setting or incident would have been no barrier. For instance, the oriental custom most frequently alluded to by English writers throughout the century is the suttee. They were impressed not only by the outlandish barbarity of the custom, but also by the universal ideal of supreme fidelity in love and heroic devotion to religious belief. Witness also the strong appeal made to-day to Western imaginations by modern versions of Afghan ballads afire with passion; or by romantic legends like that of the Persian sculptor, Farhad, and the Princess Schirin. ${ }^{1}$

${ }^{1}$ Persia, Past and Present . . b by A. V. W. Jackson . . . New York, 1906, p. 226. Cf. also The Power of Bible Poetry, by J. H. Gardiner in Atlantic Monthly, September, 1906 (Vol. XCVIII., pp. 384-394). 
But in spite of all these barriers to the free imaginative development of this fiction, - the rationalistic classicism; the moralistic, philosophic, and satiric moods; the insularity of the English people; and the alien characteristics of the oriental tale, - nevertheless, the presence and the genuine if limited popularity of this fiction in eighteenth-century England are undeniable facts. The reasons behind these facts will bring us to the question of the ultimate significance of the genre as a manifestation of the Romantic spirit.

The first and obvious reason for the welcome given the oriental tale by the London of Pope and Addison - despite Bishop Atterbury's censure - was that it came from France. Especially since 1660, French influence had prevailed in England, French literary critics were regarded as authoritative, and French fashions in literature were followed. Since, then, the vogue of the oriental tale was so great in France, it was naturally echoed in England. That the fairy tales - equally popular in France - did not cross the Channel at that time may be due to the fact that Perrault drew directly from French folk-lore, and hence made an espe- 
cial appeal to the French people; and that the Countess D'Aulnoy and other aristocratic ladies gave to the stories they retold from Straparola a prestige only local. Moreover, the fairy tales - charming, as they are - lack the quality possessed by the Arabian Nights, - what we have called "the sense of reality in the midst of unreality," a quality particularly attractive to English readers.

The same fact of French influence aceounts largely for the favourable reception given to the Turkish Spy, and later to the Lettres Persanes. The popularity of such oriental pseudo-letters in England was a part of a general European tendency. ${ }^{1}$ Similarly England had shared in a

${ }^{1}$ Cf. The Literary Remains of John Evelyn . . . edited . . . by William Upcott . . . second edition . . L London, 1834. On p. xiii Evelyn's Tyrannus or the Mode (1661) is mentioned as a "very curious and rare pamphlet to be found . . . in the second volume of the Evelyn papers," a pamphlet in which the author argues for the superiority of the Persian fashion of dress over the English. Charles II. adopted the costume for a short while, probably as a result of Evelyn's reasoning. On pp. 141-167 is printed Evelyn's A Character of England as it was lately presented in a letter to a nobleman of France (1651; third edition, 1659), a satiric jeu d'esprit, in which the author assumes the guise of a Frenchman and gives a "character" of England from the French point of view. He concludes: "In summe, my Lord, I have found so many particulars 
widely diffused interest in an analogous form of satire; that of Boccalini's Ragguagli di Parnaso, a type generally known and frequently imitated throughout seventeenth-century Europe. $^{1}$ Boccalini had imagined Apollo, king of Parnassus, conducting discussions among his courtiers, - men of genius from every nation and age, - and passing criticism on political and literary questions; Boccalini himself being the reporter who brought these "Advices" from Parnassus to Europe. The analogy between such satire and that of Marana is striking. In one sense Apollo and the departed shades, observing Europe from the remote regions of mythology, were forerunners and equivalents of the later learned Turkish spies, Persian travelers, and Chinese philosophers from the Far East. ${ }^{2}$

worthy of reproof ... that to render you a veritable account of England as it is at present I must pronounce with the poet, - Difficile est satyram non scribere."

${ }^{1}$ Cf. Trajano Boccalini's Einfluss auf die Englische Literatur, by R. Brotanek, in Archiv für das Studium der neueren Sprachen u. Literaturen, Vol. CXI. (n. s. XI.), 1903 ; cf. also Spectator, No. 514, Steele's Vision of Parnassus; Swift, Journal to Stella, Saturday, April 28th, 1711; and others.

${ }^{2}$ At the present writing there is no proof for, or against, a causal relation; it is possible that Boccalini influenced Marana, but in the absence of satisfactory 
Another reason for the welcome given the Arabian Nights and The Persian Tales is found in connection with the history of the novel. The elements of interest essential to great narrative art are plot, character, and background. Of these essentials it has been said that the Sir Roger de Coverley papers possess two: admirable characterization and well-defined background; and that the absence of plot alone denies to Sir Roger de Coverley the name of the first English novel.". Almost exactly contemporary with the De Coverley papers appeared the Arabian Nights; and, in the light of what has just been said, the auspicious reception of these oriental tales gains new significance. Stories of pure adventure, in fantastic and often brilliant setting, sometimes emotional or sentimental, never strong in characterizationthey offered just that element of plot which

evidence I do not wish to imply anything more than an interesting and suggestive analogy. Cf. P. Toldo. Dell' Espion di Giovanni Paolo Marana e delle sue attinenze con le Lettres Persanes del Montesquieu, in Giornale Storico, Vol. XXIX., pp. 46-79; esp. 53; and Antonio Belloni, in Vol. VII. of Storia Litteraria d'Italia . . I Il Seicento . . Milano, 1898-1899, p. 374.

${ }^{1}$ Cf. W. Raleigh, The English Novel . . . New York, 1904. Fifth cdition, p. 120. 
was lacking in the periodical sketches. The plot, indeed, is frequently strong only in incident, and is tangled in construction. Yet, in the Arabian Nights, there are several.tales that, in certain respects, deserve to be called classical; Ali Baba and the Forty Thieves, or Zeyn Alasnam and the King of the Genii, for instance, despite all their oriental decorations, are admirably simple and well-proportioned; and the Arabian Nights, as a whole, is a treasure-house of story perhaps unsurpassed in literature. Nothing so rich in adventurous incident appeared in England until Robinson Crusoe (1719); and in plot nothing so well-constructed as some of these tales until Fielding's masterpieces. Historians of English fiction have insufficiently recognized the fact that the oriental tale was one of the forms of literature that gave to the reading public in Augustan England the element of plot which, to a certain extent, supplemented that of character, afforded by sketches like the De Coverley papers. The English novel, as a recent writer has pointed out in his admirable outline of its history, is particularly rich in the variety of elements assisting in its development. Of the seventeenth century he writes: 
"The heroic romance died and left no issue. And the influence that the century exercised on the growth of pure fiction, the foundations it laid for the coming novel, are to be sought, not in the writers of romance, but in the followers of other branches of literature, often remote enough from fiction, in satirists and allegorists, newspaper scribes and biographers, writers of travel and adventure, and fashionable comic playwrights." 1 Yet the translators of oriental fiction in the early eighteenth century "writers of romance" in one sense though they were - deserve a place among these diverse influences. The Arabian Nights was the fairy godmother of the English novel.

But the love of story for the story's sake was not the only or the chief reason for the welcome given the Arabian Nights and its immediate successors. In France, the popularity of these fantastic and marvelous stories, restless in plot and exuberant in colour, had testified to a truant desire to escape from the strict artistic rules and classical ideals of masters like Boileau. Conditions were similar in England. Pseudoclassicism was the natural literary ideal of the

$$
{ }^{1} \text { W. Raleigh, op. cit., p. } 109 .
$$


men gathered in the coffee-houses around Pope and Addison. The rule of reason, of order, of good sense, was unquestioned; and, to so keen and clever a society, the satiric verse of Pope was ideal poetry. But even the author of the Essay on Criticism allowed his fancy to stray at times beyond the well-defined limits of traditional art. He enjoyed the Arabian Tales, commended them to his friend, Bishop Atterbury, ${ }^{1}$ and planned himself to write a "wild" Eastern tale." Lady Montagu did much to excite and to gratify curiosity concerning Turkish life by her entertaining letters from Constantinople. ${ }^{3}$ Swift read the Arabian Nights and fairy tales. He writes to Stella: "I borrowed one or two idle books of Contes des Fées and have been

${ }^{1}$ Works of A. Pope . . edited by Rev. W. L. Bowles, London, 1806, Vol. VIII., pp. 110-112; Vol, IX., p. $372, \mathrm{n}$.

${ }^{2}$ Spence; op. cit., on p. 77, n. 2 ; p. 169 . "After reading the Persian Tales (and I had been reading Dryden's Fables just before them) I had some thoughts of writing a Persian Fable; in which I should have given full loose to description and imagination. It would have been a very wild thing if $I$ had executed it, but might not have been unentertaining."

${ }^{3}$ During her husband's embassy there, 1711-1718. Letters and Works of Lady Mary Wortley Montagu . . . new edition, 2 vols., London, 1887. The date of the first edition of Turkish Letters was 1763. 
reading them these two days, although I have much business upon my hands." 1 Goldsmith dreamed ardently of a journey to the Far East, 2 and Dr. Johnson himself came somewhat under the oriental spell. The men of the eighteenth century were not devoid of passion and imagination; they were not without a love for the country, though they liked the town far better; they were not without an appreciation of nature, though they preferred cultivated plains to "horrid Alps"; but they considered it bad form to express such feelings in polite society or in serious literature. Oppressed by the bare and hard rationalism of the day, people craved more and more earnestly adequate food for their imagination, their fancy, their emotion. This hunger explains the growing interest in varied fields of artistic activity: the popularity of the new Italian operas and of Handel's oratorios, the vogue of the bourgeois drama, the interest in Hogarth's realistic art, and the appearance of nature poetry like Thomson's Seasons.

${ }^{1}$ Swift's Journal to Stella. A.D. 1710-1713, edited . . . by F. Ryland, London, 1897 , p. 327. Letter XL., January $26,1711-1712$.

${ }^{2} \mathrm{Cf}$. numerous references in Oliver Goldsmith . . . by W. Irving. Hudson edition . . . New York, 1864. 
To the general though gradual romantic expansion of outlook there are many witnesses; and it is significant to note that the strand of interest in the Orient is interwoven with other romantic threads. As early as 1692, Sir Wil- . liam Temple shows interest in Norse poetry and mythology, in Indian and Chinese life and art. ${ }^{1}$ Addison soon follows with his defense of Chevy Chase; Ambrose Philips, the translator of the Persian Tales, also edits old English ballads, and Bishop Percy, toward the end of the period, manifests a curious range of interest: English ballads, Northern antiquities, Chinese literature, etc. ${ }^{2}$ Similarly in France, Caylus, Pétis de la Croix, and Galland had been antiquarians as well as orientalists. In such a widening of outlook the Romantic Movement resembles the Renaissance.

The chief reason, then, for the popularity of the oriental fiction was its romantic character. No wonder that the growing demands of the

${ }^{1}$ Works of Sir William Temple, Bart., Vol. III., London, 1757, pp. 304-393; Of heroic Virtue, pp. 430-472. An essay upon Ancient and Modern Learning.

${ }^{2}$ To this list other names might be added, e.g. that of Clara Reeve, author of The Old English Baron and editor of Charoba. 
reaction against pseudo-classicism found a certain satisfaction in these extraordinary tales, which brought into the comparatively gray and colourless life of Augustan England the fascinating marvels of oriental legend, encompassed, even in the translations from the French, by something of the magical atmosphere and strange glamour of the East. It would be as difficult as superfluous to analyze the world-wide charm of these tales. The caliph in disguise, wandering the streets of Bagdad in search of adventure, appeals to the same naive sense of delight that is excited by Richard Cœur-de-Lion or Robin Hood. There is in most people at all times something of the child's love of the marvelous. In the eighteenth century a special reason for the popularity of these tales lay in the fact that they offered to the reactionary spirit, always characteristic of romanticism, romantic themes and treatment, and voiced the romantic mood. In varying degree these stories show a love of adventure and of mystery; a desire to excite the feelings of surprise, horror, or delight; a child's joy in the extravagant, the unusual, and the exotic; and an equally childlike desire to achieve the 
apparently impossible. The Persian Tales is tinged with sentimentalism; Anglicized tales such as Rasselas sound a decided note of subjectivity and melancholy; Vathek is unreal and "wild." It is interesting to find Horace Walpole calling his Castle of Otranto "so wild a tale," for just this quality of wildness in both the oriental and the Gothic tale manifests romantic longings. In the one there is the reactionary desire to escape to the far-away, mysterious East, - the remote in space; in the other, the desire to return to the Middle Ages, - the remote in time; in both, the longing for picturesque colouring, for magical atmosphere, for strangeness, coupled sometimes with beauty, sometimes with horror.

But, it may be said, the oriental tale is romantic only in external qualities, and should be classed as pseudo-romantic. Every romantic revival passes through a stage of what may be called pseudo-romanticism or, more accurately, superficial romanticism, gradually deepening and strengthening as it grows toward its culmination. The movement known in literary history as the Romantic Movement in England began almost imperceptibly early in the eigh- 
teenth century. Its sources were as diverse as those of the English novel. If we take as the highest standards of English romanticism the picturesque, objective mediævalism of Scott; the deep spirituality of Wordsworth; the intense subjectivity of Emily Bronte; Shelley's "cloudless clarity of light"; the strange beauty of Keats's verse, - the sense of melancholy, of mystery, of sympathy with sorrow found in all great romantic poets, - then the beginnings of English romanticism seem what they are, mere beginnings, so remote from the great romantic literature that the difference in degree amounts to a difference in kind. From this point of view, critical analysis, noting that the Gothic tale and the oriental tale lack the more subtle and essential elements of the romantic spirit, justly regards them as romantic only in externals.

Yet romanticism is a relative term; and if all that is not romantic in the highest sense be dismissed as unromantic, there is great danger of ignoring the gradual evolution of the profounder elements of the romantic spirit and of overlooking the genuine romanticism latent or obscured in early romantic art. Critics of classicism, who regard solely the highest forms 
in which that literary tendency embodies itself, often pay the penalty of losing perspective, of disregarding evolution. If the great classics Homer, Asschylus, Virgil - be taken as the norm, then works of the later Greek or Roman periods, or the so-called "classic" period in France, may be regarded justly as pseudoclassical. At the same time, genuinely classical qualities are present in Racine and Corneille, and must be recognized, together with the equally obvious pseudo-classical elements, as contributing to the evolution of French classicism. Here, again, it is a question of the point of view. Criticism may consider a work of art in the light of the absolute standard, - the ideal, - and may also consider it in relation to the evolution of literary types or tendencies.

In judging a romantic revival, such criticism finds its task at once peculiarly difficult and peculiarly interesting; for the very nature of romanticism is elusive, and its methods are those of symbolism and suggestion rather than of clear definition. Yet, taking a broad view over the entire romantic revival in England, - and the same holds true of France in even greater de- 
gree, - one can see clearly that the orientalism and pseudo-orientalism of the eighteenth century distinctly preluded the use of oriental material by the romantic writers of the early nineteenth century. As Allan Ramsay and Thomson prepared the way for Burns and Wordsworth, so, less obviously, but none the less truly, the translators and writers of the oriental tale, together with historians and travelers, were forerunners of Southey, Moore, Byron, Matthew Arnold, Fitzgerald, and many others, on to Kipling in the present day.

Moreover, the oriental tale directly contributed romantic elements to the imaginative inheritance of later writers. Its influence is clearly traceable throughout the entire nineteenth century. We have seen that the History of Charoba was the acknowledged inspiration of Landor's Gebir. Vathek exerted great influence on Byron's youthful work, an influence easily understood if one recalls the mockery, the sensuousness, and the brilliant setting of Beckford's masterpiece, and especially the sinister horror of the catastrophe. ${ }^{1}$ Barry Cornwall drew more definitely from Vathek in his brief ${ }^{1}$ Cf. App. A, pp. 258, 259, Byron. 
poem, The Hall of Eblis.' Beckford himself borrowed directly from the Adventures of $A b$ dalla and the Mogul Tales. ${ }^{2}$ Lewis may have derived his tale of terror, The Monk, from a Turkish Tale. ${ }^{3}$ Possibly Swift also drew from the Turkish Tales. ${ }^{4}$ Smollett makes Lydia, the sentimental country heroine of Humphrey Clinker, compare the "grandeur" of London to the dazzling enchantments of oriental story." Southey explicitly states his indebtedness to the New Arabian Nights for the idea of Thalaba.4 James Thomson (1834-1882), with equal frankness, acknowledges his obligation to the Arabian Nights, in the case of The Doom of a City. Tennyson's early poem, Recollections of the Arabian Nights, is a good instance of the strong appeal made to youthful imagination by the splendours of

\section{" the golden prime}

Of good Haroun Alraschid." 5

${ }^{1}$ Cf. Source of the Hall of Eblis by B. Cornwall, by $\mathbf{H}$. Jantzen, Archiv für das Studium der neueren Sprachen $u$. Literaturen ... Vol. CVIII. (n. s. VIII.), 1902, p. 318 et seq.

${ }^{2}$ Cf. Chap. I., pp. 36-38. $\quad{ }^{3}$ Cf. Chap. I., p. 27.

${ }^{4}$ Cf. App. A, pp. 259-262, Swift; 262, 263, Smollett; 263 , Southey and Thomson.

${ }^{5}$ Cf. on the "goodness" of Haroun Alraschid, J. Payne: The Book of the Thousand Nights and One Night, in nine volumes . . . London, 1884, Vol. IX. Concluding Essay. 
Wordsworth and Scott, as schoolboys, came eagerly under the spell.

"The tales that charm away the wakeful night In Araby"

were to Wordsworth a precious treasure, setting free the child's imagination. ${ }^{1}$ Part of the romantic charm of Venice in Wordsworth's eye, was that

"Once did she hold the gorgeous East in fee."

Scott's mature imagination also retained an interest in the Orient; witness The Talisman, The Surgeon's Daughter, Count Robert of Paris, and possibly the arrow contest in The Monastery. ${ }^{2}$ De Quincey, in one of the most interesting passages in his Autobiography, ${ }^{3}$ after disparaging remarks concerning Sindbad and Aladdin, goes on to say that one solitary section

${ }^{1}$ Cf. App. A, pp. 263-265, Wordsworth; 265, Scott; 265, 266, Dickens; 266, Thackeray.

${ }^{2}$ V. Chauvin, Bibliographie des ouvrages arabes, Vol. VI., \$286 n., "Pari Banou." In Waverley, Chap. V., Scott refers to Prince Hussain's tapestry and Malek's flying sentry-box. The subtitle of The Betrothed is A Tale of the Crusaders, but the story is in no respects oriental.

${ }^{3}$ The Collected Writings of Thomas De Quincey... edited by David Masson, Edinburgh, 1889, Vol. I., pp. 127-130. Cf. Revue des deux Mondes, 1896, Vol. 138, pp. 121, 122. 
of the latter story "fixed and fascinated" his gaze: the incident of the murderous magician, - who could gain the lamp only by the aid of a pure child, - listening with ear to the ground in order to distinguish the footsteps of his innocent young victim thousands of miles away. Dickens in David Copperfield, Thackeray in Vanity Fair and The Virginians, and Stevenson in many passages, testify to a fondness for oriental tales. Instances might be multiplied, but enough have been given to show clearly that the oriental tales, from the early versions of the Arabian Nights on, have had a distinct value in stimulating the imagination of numerous writers and countless readers. ${ }^{1}$ In all these cases, the vital and life-giving elements in this fiction have been the picturesque and suggestive details about strange oriental customs; mysterious ideas like metempsychosis; entertaining narrative; richness of invention, - in short, the romantic qualities. These have constituted the

${ }^{1}$ Cf. V. Chauvin, op. cit., Vol. VI., for influence of Arabian tales on European writers. Of course nineteenth-century authors were influenced also by versions of the Arabian Nights later than those of the period under discussion, e.g. those of J. Scott, Burton, Lane, Payne, etc. 
chief charm of oriental story from the time of Addison to the present day.

It must always be remembered that the oriental tale met with disapproval as well as with favour. The full significance of the genre is understood only when we recognize it as a test of the public opinion of the age concerning romanticism, and not merely as a witness to the romantic mood. On the one hand, condemned by typical men of letters as "wild" and "romantick," it reveals the strength of Augustan classicism as the law of the land; on the other, welcomed with enthusiasm, persisting in one form or another throughout the century, utilized even by such defenders of the classical stronghold as Dr. Johnson, ${ }^{1}$ it testifies, by its mere presence, to the new spirit of romanticism.

But before the death of the last great classicist of the century new forces were already at work, which were to bring the Orient much nearer to England than ever before. The growth of the Indian empire, of commercial intercourse with the East, and of the new democratic belief in the brotherhood of the whole

${ }^{1}$ On one aspect of the duality in Dr. Johnson's nature, cf. The Prayers of Dr. Johnson, edited by W. A. Bradley, New York, 1902, pp. 84, 85. 
world, helped to break down England's insularity and to awaken a fresh interest in the Orient. In letters, this modern spirit was first expressed by the increased number of travelers' accounts, and by the accompanying activity of orientalists under the guidance of Sir William Jones. Direct translations from oriental languages into English made a notable contribution to English knowledge of Eastern life and literature, and had a large share in turning the imaginations of nineteenth-century poets and story-tellers toward the use of oriental material. A fresh chapter in the history of oriental influence upon England thus opened. This chapter - still in the making - has been distinguished throughout its entire course by actual first-hand knowledge of the Orient, - one vital characteristic which throws it into sharp contrast with the chapter discussed in the present volume. But to consider even the beginnings of the modern period, in the new scholarly movement inaugurated by Sir William Jones, would carry us beyond the limits of our subject. By the time the new movement was well under way, the oriental tale of the eighteenth century had done its work and had passed on its inheritance to its successors. 


\section{APPENDIX A}

\section{NOTES}

Page 204, Sterne. The manuscript of Sterne's Bramine's Journal, now in the British Museum (Add. Ms. 34,527), is exhibited with the following note: "The Bramine's Journal, being Sterne's Journal addressed to Mrs. Eliza Draper after her departure for India. It extends from 13 April (1767) to 4 August with a postscript on 1 Nov. and is entirely in the author's hand. It is full of expressions of extreme devotion, and was discontinued on the arrival of Mrs. Sterne. At the beginning is a note (evidently prefixed with a view to publication) stating that the names are fictitious and the whole translated from a French manuscript. The page exhibited contains the record for 17 June: 'I have brought your name Eliza! and Picture into my Work [The Sentimental Journey, see the page exhibited above, No. 23] where they will remain when you and $I$ are at rest forever. - Some annotator or explainer of my works in this place will take occasion to speak of the Friendship which subsisted so long and faithfully betwixt Yorick and the Lady he speaks of.' See also the letter of W. M. Thackeray exhibited in Case VII., No. 44, written after reading the Ms. [Add. Ms. 
34,527]. Bequeathed in 1894 by T. W. Gibbs, Esq." In Case VII. the letter exhibited reads as follows: “ He wasn't dying, but lying, I'm afraid — God help him - a falser and wickeder man it's difficult to read of. ... . Of course any man is welcome to believe as he likes for me except a parson: I can't help looking upon Swift and Sterne as a couple of traitors and renegades - . . . with a scornful pity for them in spite of their genius and greatness." "Dated 12 Sept. [1851] Holograph. [Add. Ms. 34,527, f. 75.] Bequeathed in 1894 by T. W. Gibbs, Esq."

Page 251, note 1, Byron. On Byron's indebtedness to the oriental tale, ef. (a) Die Belesenheit des jungen Byrons . . . Dissertation . . von Ludwig Fuhrmann, Berlin, 1903, pp. 60, 61, also 5, 6.

(b) Byron's und Moore's Orientalische Gedichte, Eine Parallele . . Dissertation . . von O. Thiergen. Leipzig, 1880.

(c) Byron und Moore ... Dissertation ... von Edgar Dawson. Leipzig, 1902, p. 60.

(d), (1), Childe Harold, Canto I., 22, note by editor. Works of Lord Byron . . . edited by T. Moore, in 14 vols., Vol. VIII. London, 1832: "'Vathek' (says Lord Byron in one of his diaries) was one of the tales I had a very early admiration of. For correctness of costume, beauty of description, and power of imagination, it far surpasses all European imitations; and bears such marks of originality, that those who have visited the East will find some difficulty in believing it to be no more than a translation. As an Eastern tale, even 
Rasselas must bow before it: his ' happy valley' will not bear a comparison with the "Hall of Eblis.'"

(2) The Siege of Corinth, same edition, Vol. X., p. 131, Byron acknowledges that an idea in certain lines was drawn from Vathek, and then goes on to say, "[Vathek is] a work to which I have before referred; and never recur to, or read, without a renewal of gratification."

(3) The Giaour, same edition, Vol. IX., p. 178,

"To wander round lost Eblis throne; And, fire unquenched, unquenchable, Around, within thy heart shall dwell;" etc.

(4) Manfred, Act II., Sc. 4, p. 112 and notes. Poetry, Vol. IV., of The Works of Lord Byron . . . edited by E. H. Coleridge . . L London . . . New York, 1901. Byron's note at beginning of the scene, "The Hall of Arimanes - Arimanes on his Throne, a Globe of Fire, surrounded by the Spirits."

Page 252, note 4, Swift. (In strict compliance with our avowed exclusion of Hebrew literature from our subject, the following note would be omitted. But since the Turkish Tales is little known to-day, the student of Swift may find it convenient to have access to this curious story here.) In the Turkish Tales, the story of the King of Aad, a distorted legend ${ }^{2}$ based

1 I am informed by Professor Charles C. Torrey of Yale University, that this legend, of the duel between Moses and "Auj" (Og, King of Bashan), is found in the oldest Arabic history of Egypt, written about the middle of the ninth century A.D. 
on the conflict of the Children of Israel with Og, King of Bashan and the Sons of Anak, reads as follows [abridged from H. Weber : Tales of the East, Edinburgh, 1812, Vol. III., p. 198]:-

"Aoudge-Ibn-Anak, King of Aad, being informed that the prophet Mousa, at the head of 600,000 Israelites, was coming to preach the Jewish religion to him, sent an army. ... The prophet was strangely surprised when he saw the King of Aad's troops . . . whose children were above an hundred feet high. His zeal then cooled a little; and before coming into action, . . . he sent twelve doctors to tell their prince that it was a great pity such proper men should be ignorant of God. This compliment was not difficult to remember; and yet the doctors forgot it when they came into the presence of Aoudge, who was cutting his nails with a terrible large axe. This monstrous king, seeing the prophet's twelve doctors so affrighted that they could not speak one word, began to laugh so loud that the echo resounded for the space of fifty leagues around; he then put them all into the hollow of his left hand, and turning them about like ants with the little finger of his right hand, he said, 'If these wretched animals would but speak, we would give them to our children for playthings.' After this, he put them into his pocket and marched [against] the Israelites. When he came [near], he pulled their twelve doctors out of his pocket; but they were no sooner on the ground than they fled with all possible speed, and never looked behind them. The Jews, terrified with 
the enormous size of their enemies, abandoned their prophet. Their wives attempted in vain to animate and embolden them; but their timorous husbands forced them with them in their flight, saying, 'Let us fly, and leave the affair to the prophet. The Lord hath no occasion for anybody besides himself to work a miracle.' Mousa ... then marched singly against the people of Aad. The terrible Aoudge expected him unconcerned ... and lanced a rock at him, which had crushed the prophet if God had not sent an angel in the shape of a bird, which, with one peck of his bill, cleft the rock in two. ... Mousa then ... by a prodigious effort of the Omnipotent Power became 70 cubits higher than his natural stature; he then flew into the air for the space of 70 cubits, and his rod was 70 cubits long, with which he touched Aoudge's knee, and that prince died suddenly. The people of Aad immediately fled, and the Israelites returned to offer their service to the prophet; who said to them, 'Since you are so timorous, as not to have courage enough to follow the generous counsel of your wives, God will make you wander in the lands of Teyhyazousi, for the space of 40 years.' "

Cf. in a Voyage to Lilliput, in Gulliver's Travels, edited by G. R. Dennis, London, 1899, Vol. VIII., p. 30, of Prose Works of J. Swift, edited by Temple Scott, the incident of Gulliver's putting into his pocket five Lilliputians, who had shot arrows at him. "As to the sixth, I made countenance as if I would eat him alive. The poor man squalled terribly ... but . . . looking 
mildly . . . I set him gently on the ground, and away he ran. I treated the rest in the same manner, taking them one by one out of my pocket. ..." The picture of Aoudge holding the doctors in his hand and putting them into his pocket is quite in the manner of Swift; the mockery of the doctors and the ironical description of the courageous wives of the Jews, and of the miracle, is thoroughly Swiftian in spirit. Yet the similarity may be chance coincidence. Cf. Dennis, op. cit., Introduction, p. xxiii, on the sources of Gulliver's Travels.

Page 252, note 4, Smollett. Cf. The Works of Tobias Smollett . . . Edinburgh, 1883. On pp. 497, 498 of The Expedition of Humphrey Clinker, Lydia Melford writes about London to her friend Miss Letitia Willis at Gloucester: "All that you read of wealth and grandeur in the Arabian Nights' Entertainments and the Persian Tales, concerning Bagdad, Diabekir, Damascus, Ispahan, and Samarkand, is here realized. . . . Ranelagh looks like the enchanted palace of a genie, adorned with the most exquisite performances of painting, carving, and gilding, enlightened with a thousand golden lamps that emulate the noonday sun; crowded with the great, the rich, the gay, the happy, and the fair; glittering with cloth of gold and silver, lace, embroidery and precious stones. While these exulting sons and daughters of felicity tread this round of pleasure, or regale in different parties and separate lodges, with fine imperial tea and other delicious refreshments, their ears are entertained with the most 
ravishing delights of music, both instrumental and vocal. . . . I really thought myself in paradise."

Page 252,n.4, Southey. Cf. Thalaba the Destroyer. In the Preface to the fourth edition, Cintra, 1800, quoted on p. 6 of Vol. IV., Poetical Works of R. Southey, Boston, 1880, Southey writes: "In the continuation of the Arabian Tales, the Domdaniel is mentioned, a seminary of evil magicians, under the roots of the sea. From this seed the present romance has grown." Page 252, n. 4, James Thomson (1634-1882). Cf. Poetical Works of James Thomson, edited . . . by B. Dobell in 2 vols., London, 1895, Vol. II., p. 109, The City of Dreadful Night. Thomson says, p. 442, note 3 , "The city of the statues is from the tale of Zobeide in the History of the Three Ladies of Bagdad and the Three Calendars. This episode and the account of the Kingdoms of the Sea in Prince Beder and - impressed my boyhood more powerfully than anything else in the Arabian Nights."

Page 253, n. 1, Wordsworth. Cf. The Prelude, Book V. The Poetical Works of William Wordsworth, edited . . . by E. Dowden in 7 vols., 1.460 et seq., Vol. VII., London, 1893.

"A precious treasure had I long possessed,

A little yellow, canvas-covered book, A slender abstract of the Arabian Tales; And, from companions in a new abode, When first I learnt, that this dear prize of mine Was but a block hewn from a mighty quarry That there were four large volumes, laden all With kindred matter, 'twas to me, in truth, A promise scarcely earthly. Instantly, 
With one not richer than myself, I made

A covenant that each should lay aside

The moneys he possessed, and hoard up more,

Till our joint savings had amassed enough

To make this book our own. Through several months,

In spite of all temptation, we preserved

Religiously that vow; but firmness failed,

Nor were we ever masters of our wish.

And when thereafter to my father's house

The holidays returned me, there to find

That golden store of books which I had left,

What joy was mine! How often ...

For a whole day together, have I lain

Down by thy side, O Derwent! murmuring stream,

On the hot stones, and in the glaring sun,

And there have read, devouring as I read,

A gracious spirit o'er this earth presides, And o'er the heart of man : invisibly

It comes, to works of unreproved delight,

And tendency benign, directing those

Who care not, know not, think not what they do.

The tales that charm away the wakeful night

In Araby, romances; legends penned

For solace by dim light of monkish lamps;

Fictions, for ladies of their love, devised

By youthful squires; adventures endless,

Dumb yearnings, hidden appetites, are ours,

And they must have their food. Our childhood sits, Our simple childhood, sits upon a throne

That hath more power than all the elements.

... Ye dreamers, then

Forgers of daring tales! we bless you then.

Imposters, drivellers, dotards, as the ape

Philosophy will call you: then we feel

With what, and how great might ye are in league,

Who make our wish, our power, our thought a deed, 
An empire, a possession, - ye whom time And seasons serve; all Faculties to whom Earth crouches, the elements are potter's clay, Space like a heaven filled up with northern lights, Here, nowhere, there, and everywhere at once."

Page 253, n. 1, Scott. Cf. Autobiography in Lockhart's Life of Scott, in five vols., Vol. I., p. 29, Boston, 1902.

"In the intervals of my school hours I had always perused with avidity such books of history or poetry or voyages and travels as chance presented to menot forgetting the usual, or rather ten times the usual quantity of fairy tales, eastern stories, romances, \&c. These studies were totally unregulated and undirected. My tutor thought it almost a sin to open a profane book or poem." Cf. also references such as that in Waverley, Chap. V., to Prince Hussein's tapestry, and "Malek's flying sentry box"; and in the Introduction to Quentin Durward to the "generous Aboulcasem."

Page 253, n. 1, Dickens. (1) David Copperfield, Chap. IV. "My father had left a small collection of books. . . . From that blessed little room, Roderick Random, Peregrine Pickle, Humphrey Clinker, Tom Jones, The Vicar of Wakefield, Don Quixote, Gil Blas, and Robinson Crusoe, came out, a glorious host, to keep me company. They kept alive my fancy, and my hope of something beyond that place and time [his dreary childhood], - they, and the Arabian Nights and the Tales of the Genii, - and did me no harm."

(2) When a child, Dickens wrote a tragedy called 
Misnar, the Sultan of India, founded on the Tales of the Genii. See Life of Dickens by John Forster, Vol. I., pp. 7, 29, 34; also Chauvin, op. cit., IV., p. 11.

Page 253, n. 1, Thackeray. Cf. (1) Vanity Fair, Chap. V. "On a sunshiny afternoon ... poor William Dobbin ... w was lying under a tree in the playground, spelling over a favorite copy of the Arabian Nights - apart from the rest of the school - quite lonely and almost happy.... Dobbin had for once forgotten the world and was away with Sinbad the Sailor in the Valley of Diamonds or with Prince Ahmed and the Fairy Peribanon in that delightful cavern where the prince found her, and whither we should all like to make a tour." Chap. III. "She [Becky] had a vivid imagination; she had, besides, read the Arabian Nights and Guthrie's Geography."

(2) The Virginians, Chap. XXIII. Hetty Lambert "brought out 'The Persian Tales' from her mamma's closet." Chap. XXX. Harry Warrington writes home of reading "in French the translation of an Arabian Work of Tales, very diverting."

(3) Roundabout Papers. In the paper "On a Lazy, Idle Boy," Thackeray refers to "a score of whitebearded, white-robed warriors, or grave seniors of the city, seated at the gate of Jaffa or Beyrout, and listening to the story teller reciting his marvels out of The Arabian Nights."

(4) Eastern Sketches contains many references to the pleasure Thackeray has always taken in the Arabian Nights, e.g. pp. 338, 339, of Works, Vol. X. 


\section{APPENDIX B. I.}

\section{CHRONOLOGICAL TABLE}

A list of the more important oriental tales published in English during the period under consideration. The order of arrangement is determined by the date of the earliest edition extant. The works of each author are grouped under his name. Editions given immediately after the titles are first editions uniess otherwise stated. Editions starred are those referred to in the text or notes.

Abbreviations: $\mathrm{Sp} .=$ Spectator $; \mathrm{Gu} .=$ Guardian; $\mathrm{Fr} .=$ Freeholder Ra. $=$ Rambler $; \mathrm{Adv} .=$ Adventurer $;$ Wo. $=$ World $;$ Con. $=$ Connoisseur $; \mathrm{Ba} .=$ Babler $; \mathrm{Id} .=$ Idler $; \mathrm{Mir} .=$ Mirror; Obs. $=$ Observer $;$ tr. $=$ translated .

1. 1687. Marana, Giovanni Paolo. Letters writ by a Turkish Spy, who liv'd five and forty years... at Paris: giving an Account ... of the most remarkable transactions of Europe ... from 1637 to 1682 [tr. from French, by W. Bradshaw, and edited by Robert Midgley, M.D.], 8 vols., London, 16871693. Twenty-second edition, $1734 ; \ldots$ edition, * 1748; twenty-sixth edition, 1770 .

2. 1700, Brown, Thomas. Amusements Serious and Comical Calculated for the Meridian of London, separately published in 1700; and also in the Works of Thomas Brown, in three volumes, with a Character of the author by James Drake, M.D., *1707-1708. 
Cf. the four volumes in the Boston Athenæum; (a) the title-page of the first volume reads, The Works of Thomas Brown, Serious, Moral, Comical and Satyrical In Four Volumes, containing Amusements [then follows table of contents of all four volumes]. To which is prefixed a Character of Mr. Brown and his Writings, by James Drake, M.D. The Fourth edition, Corrected, with large Additions, and a Supplement, London. Printed for Samuel Briscoe, 1715; (b) the title-page of the third volume reads, The Third Volume of the Works of Mr. Tho. Brown, Being Amusements, Serious and Comical, Calculated for the Meridian of London. Letters Serious and Comical to Gentlemen and Ladies. Eneas Sylvius's Letters in English. A Walk around London and Westminster, Exposing the Vices and Follies of the Town. The Dispensary, a Farce. The London and Lacedemonian Oracles. The Third Edition, with large Additions. London, Printed for Sam. Briscoe, and sold by J. Morphew near Stationers' Hall,* 171- [date imperfect, conjecture: 1711]. In the last-named volume, "A Walk around London and . . . the Town," p.244, is entitled also, The Second Part of the Amusements Serious and Comical.

3. 1700. [Avery, John]?

(a) The Life and Adventures of Captain John Avery ... now in possession of Madagascar written by a person who made his escape from thence, 1700.

(b) The King of the Pirates, being an account of the Famous Enterprises of Captain Avery, the Mock 
King of Madagascar, with His Rambles and Piracies, wherein all the Sham Accounts formerly publish'd of him, are detected. In two Letters from Himself: one during his Stay at Madagascar and one since his Escape from thence, London, 1720. [According to J. K. Langton in Dict. Nat. Biog. article, "John Avery," (b) has been attributed to Defoe, and both $(a)$ and $(b)$ are "fiction, with scarcely a substratum of fact"].

4. Between 1704 and 1712. Arabian Nights Entertainments: consisting of One Thousand and One Stories, told by the Sultaness of the Indies, to divert the Sultan from the Execution of a bloody vow . . ., containing a better account of the Customs, Manners, and Religion of the Eastern Nations, viz.: Tartars, Persians and Indians, than is to be met with [in] any Author hitherto published. Translated into French from the Arabian MSS. by M. Galland, ... and now done into English from the third Edition in French. . . . The fourth Edition, London, Printed for Andrew Bell, In 12 [vols. 1-6], *1713-1715. First edition, date unknown; second edition, $* 1712$; edition called the fourteenth edition, London, $* 1778$, 4 vols. [ = " the oldest edition which $I$ have seen containing the latter half of Galland's version." W. F. Kirby in App. II., p. 467, Vol. X., of Burton's Arabian Nights, Benares, 1884].

5. 1705. Defoe, Daniel.

(a) The Consolidator: or Memoirs of Sundry Transactions from the World in the Moon, Translated 
from the Lunar Language. By the Author of the True-Born Englishman, London, . . . *1705.

(b) The Farther Adventures of Robinson Crusoe, London, $* 1719$.

(c) A System of Magic, London, *1726.

6. 1707. Arimant and Tamira; an eastern tale [in verse] In the manner of Dryden's fables; By a gentleman of Cambridge. London, 1707.

7. 1708. Turkish Tales; consisting of several Extraordinary Adventures: with the History of the Sultaness of Persia and the viziers. Written Originally in the Turkish Language by Chec Zade, for the use of Amurath II., and now done into English. London . . J Jacob Tonson, *1768. Cf. also No. 15 (b) below: 1714, Persian and Turkish Tales compleat.

8. 1708. Abu Jaafar Ebn Tophail. The Improvement of Human Reason, exhibited in the Life of Hai Ebn Yokdhan; Written in Arabick above 500 years ago, by Abu Jaafar Ebn Tophail. . . . Translated by Simon Ockley ...., London ....*1708; another edition, 1711. The first English version was published in 1674, anonymously, with the title "An Account of the Oriental Philosophy . . . [etc.]." Cf. Brit. Mus. Catalogue under "Abu Jaafar Ebn Tophail," and Dict. Nat. Biog. under "Geo. Ashwell" (16121695). Cf. for full title of Ockley's translation, pp. 126,127 , ante.

9. (1710?). Ali Mohammed Hadji (pseud.). A brief and merry History of Great Britain, containing an account of the religion, customs . . . etc. of the people, written 
originally in Arabick by Ali Mohammed Hadji. . . . Faithfully rendered into English by A. Hillier, London (1710?). Another edition, $* 1730$.

10. 1711. Bidpai. Principal eighteenth-century versions. (1) Esop Naturalized, in a collection of fables and stories from Esop . . . Pilpay and others ... London, $* 1711$; another edition, 1771 ; (2) The Instructive and Entertaining Fables of Pilpay, an ancient Indian Philosopher, containing a number of excellent rules for the conduct of persons of all ages. London, 1743. [This is a reproduction of the 1679 version, "Made for the Duke of Gloucester."] Other editions, 1747, 1754; fifth edition, 1775; sixth edition, 1789. Cf. Chauvin, Bibliographie, II., pp. 33, 40, 70, and Table opposite p. 1. The earliest English version of Bidpai is Sir Thomas North's Morall Philosophie of Doni . . 1570.

11. 1711. Addison, Joseph.

[Sp. No. 50, April 27, 1711. Observations by four

Indian Kings.]

Sp. No. 94, June 18, 1711. (1) Mahomet's journey to the seven heavens. (2) The adventures of the Sultan of Egypt.

Sp. No. 159, Sept. 1, 1711. The Vision of Mirza. Sp. No. 195, Oct. 13, 1711. Story of sick king cured by exercise with drugged mallet.

[Sp. No. 237, Dec. 1, 1711. Jewish tradition concerning Moses.]

Sp. No. 289, Jan. 31, 1711-1712. Story of the dervish who mistakes a palace for an inn. 
Sp. No. 293, Feb. 5, 1711-1712. Persian fable of drop of water which became a pearl.

Sp. No. 343, April 3, 1712. Story of Pug the monkey. Sp. No. 349, April 10, 1712. Story of courageous Muli Moluc, Emperor of Morocco.

Sp. No. 511, Oct. 16, 1712. (1) Persian marriageauction. (2) Merchant who purchased old woman in a sack.

Sp. No. 512, Oct. 17, 1712. Story of Sultan Mahmoud and his vizier.

Sp. No. 535, Nov. 13, 1712. Story of Alnaschar.

Gu. No. 99, July 4, 1713. Persian story of just sultan. Gu. No. 167, Sept. 22, 1713. Story of Helim and Abdallah.

Sp. No. 557, June 21, 1714. Letter to the King of Bantam.

Sp. Nos. 584 and 585, Aug. 23 and 25, 1714. Story of Hilpa, Harpath, and Shalum.

Fr. No. 17, Feb. 17, 1716. Persian Emperor's riddle. 12. 1712. Unknown Contributors to Guardian and Spectator.

Gu. No. 162, Sept. 16, 1712. Story of Schacabac and the Barmecide.

Sp. No. 578, Aug. 9, 1714. Story of Fadlallah and Zemroude.

Sp. No. 587, Aug. 30, 1714. Story of Mahomet, Gabriel, and the black drop of sin. Sp. No. 604, Oct. 8, 1714 . Vision at Grand Cairo. Sp. No. 631, Dec. 10, 1714. Story of the dervise who forgot to wash his hands. 
13. 1713. Pope, Alexander.

Gu. No. 61, May 21, 1713. Fable of the traveller and the adder.

14. 1712. Steele, Sir Richard.

Sp. No. 545, Nov. 25, 1712 . Letter from the Emperor of China to the Pope.

Gu. No. 148, Aug. 31, 1713. Story of the Santon Barsisa.

15. 1714. Persian Tales.

(a) The Thousand and One Days, Persian Tales. Translated from the French by Mr. Ambrose Philips. London, *1714-1715. [Cf. Chauvin, Bibliographie, IV., pp. 123-127.] Third edition, 1722 ; fifth, 1738; sixth, 1750; *seventh, 1765; other editions, 1781, 1783.

(b) The Persian and the Turkish Tales compleat [sic] Translated formerly from those languages into French [or rather compiled] by M. Pétis de la Croix . . . [assisted by A. R. Le Sage] and now into Englsh [sic] from that translation by . . Dr. King, and several other hands. To which are added; Two letters from a French Abbot to his friend at Paris, giving an account of the island of Madagascar; and of the French Embassador's reception by the King of Siam. London, *1714.

(c) Cf. Edward Button, A New Translation of the Persian Tales, London, 1754; and the anonymous Persian Tales designed for use and entertainment, *Coburg, 1779-1781.

16. 1717. Kora Selyn Oglan (pseud.). The Conduct of 
Christians made the sport of Infidels in a letter from a Turkish merchant at Amsterdam to the Grand Mufti at Constantinople on occasion of . . . the late scandalous quarrel among the clergy, $* 1717$.

17. 1720. Brémond, G. De. The Beautiful Turk, Translated from the French original, Printed in the Year 1720. [London.] This is another translation of the French tale by G. de Brémond translated "by B. B." as Hattige or the amours of the King of Tamaran, published in Amsterdam, 1680; and also in Vol. I., *1679 or 1683 (?) in R. Bentley's Modern Novels.

18. 1722. (Dec. 11, 1721.) Parnell, Thomas. The Hermit, printed posthumously in Poems on Several Occasions. - Written by Dr. Thomas Parnell, late Arch-Deacon of Clogher : and pubtished by Mr. Pope. London, *1722 (Dec. 11, 1721). For numerous volumes containing this poem, see Brit. Mus. Catalogue. 19. 1722. Aubin, Mrs. Penelope. The Noble Slaves, or the Lives and Adventures of Two Lords and Two Ladies (in Aubin's Histories and Novels), London, *1722. Another edition, Dublin, (1730); also in Mrs. E. Griffith's collection, 1777.

20. 1722. Mailly [or Mailli], Chevalier de. The Travels and Adventures of three princes of Sarendip. Intermixed with eight delightful and entertaining novels, translated from the Persian [or rather the Italian of Chr. Armeno] into French, an [sic] from thence done into English. London, *1722.

21. 1725. Segrais, J. Regnauld de. Bajazet or The 
Imprudent Favorite, in Five Novels Translated from the French. London, *1725.

\section{1725. Gueullette, Thomas Simon.}

(a) Chinese Tales, or the wonderful Adventures of the Mandarin Fum-Hoam translated from the French [of T. S. Gueullette]. London, 1725. Another translation, Chinese Tales ... Fum-Hoam ... translated by the Rev. Mr. Stackhouse, London, n.d. (Cook's pocket edition of select novels). Another edition, *1781.

(b) Mogul Tales . . Now first translated into English . . With a prefatory discourse on the usefulness of Romances. London, $* 1736$. Second edition, 1743.

(c) Tartarian Tales, or a thousand and one Quarters of Hours, Written in French by the celebrated Mr. Guelletee [sic] Author of the Chinese, Mogul and other Tales. The whole now for the first time translated into English by Thomas Flloyd. London, printed for J. and R. Tonson in the Strand, $* 1759$. Another edition, Dublin, printed for Wm. Williamson, Bookseller, at Mæcenas's Head, Bride St., 1764; another edition, London, 1785; printed in the Novelist's Magazine, 1785.

(d) Peruvian Tales related in one thousand and one hours, by one of the select virgins of Cuzco to the Ynca of Peru . . . Translated from the original French by S. Humphreys (continued by J. Kelly). Fourth edition. London, 1764. Another edition, 1786.

23. 1729. Bignon, Jean Paul. Adventures of Abdalla, 
Son of Hanif, sent by the Sultan of the Indies to make a Discovery of the island of Borico . . . translated into French from an Arabick manuscript . . by $M r$. de Sandisson [pseud.] . . . done into English by William Hatchett. . . . London, * 1729. Second edition, $* 1730$.

24. 1730. Montesquieu, C. de Secondat, Baron de. Persian Letters Translated by Mr. Ozell. London, *1730. Third edition, 1731; sixth edition, anon., Edinburgh, $* 1773$.

25. 1730. Gomez, Mme. Madeleine Angelique (Poisson) de. Persian Anecdotes; or, Secret memoirs of the Court of Persia. Written originally in French, for the Entertainment of the King, by the celebrated Madame de Gomez, Author of La Belle Assemblee. Translated by Paul Chamberlain, Gent. London *1730. The title in the British Museum Catalogue reads, " The Persian Anecdotes . . . Persia, containing the history of those two illustrious heroes, Sophy-Ismael, surnamed the Great, and Tor, King of Ormus, etc. [Translated from the French by P. Chamberlen.] London, 1730."

26. 1731. [Boles, W.?] Milk for Babes, Meat for Strong Men and Wine for Petitioners, Being a Comical, Sarcastical, Theological Account of a late Election at Bagdad, for Cailiff of that City. Faithfully Translated from the Arabick, and Collated with the most Authentic Original Manuscripts. By the Great, Learned and Most Ingenious Alexander the Copper Smith. . . S Second edition, Cork, *1731. 
27. 1733. [D'Orville, Adrien de la Vieuville.] The Adventures of Prince Jakaya or the Triumph of Love over Ambition, being Secret Memoirs of the Ottoman Court. Translated from the Original French.... London, *1733.

28. 1735. Lyttelton, George, First Baron (1709-1773). Letters from a Persian in England to his friend at Ispahan. London, *1735. Fifth edition, 1774; printed also in Harrison's British Classicks, Lopdon, *1787-1793. Vol. I.; and in numerous editions of Lyttelton's Works. See Brit. Mus. Catalogue.

29. 1735. Crébillon, C. P. Jolyot de.

(a) The Skimmer, or the history of Tanzai and Neardarné (a Japanese tale), tr. from the French. - 1735. Another edition, 1778.

(b) The Sopha, a moral tale, tr. from the French (a new edition). . . . London, 1781.

30. 1736. The Persian Letters, continued. Third edition, London, *1736 [" erroneously ascribed to Lord Lyttelton," Dict. Nat. Biog.].

31. 1739. Boyer (Jean Baptiste de) Marquis d'Argens. Chinese Letters; being a philosophical, historical, and critical correspondence between a Chinese Traveler at Paris and his countrymen in China, Muscovy, Persia, and Japan. Translated ... into [or rather written in] French by the Marquis d'Argens; and now done into English.... London, *1741.

32. (17-?). Bougeant, G. H. The Wonderful Travels of Prince Fan-Feredin, Translated from the French 
[of G. H. Bougeant, *1735], Northampton, n.d. For full title, cf. p. 213, ante.

33. 1741. Haywood, Mrs. Eliza. The Unfortunate Princess, or the Ambitious Statesman, containing the Life and surprizing [sic] Adventures of the Princess of Ijaveo [Ijaves], Interspers'd with several curious and entertaining Novels. London, $* 1741$.

34. 1742. Collins, William. Persian Eclogues, Written originally for the entertainment of the Ladies of Tauris and now translated, $* 1742$; reprinted $* 1757$ as Oriental Eclogues.

35. 1744. The Lady's Drawing Room . . . interspersed with entertaining and affecting Novels. London, *1744 [contains The History of Rodomond and the Beautiful Indian, and The History of Henrietta de Bellgrave].

36. 1745. Caylus, A. C.P. de Tubières, Comte de. Oriental Tales, collected from an Arabian Manuscript in the Library of the King of France. . . London, *1745. Another edition (1750?).

37. 1745. Vieux-maisons, Mme. de or Pecquet, A. (?). The Perseis, or secret memoirs for a History of Persia [a political satire], translated from the French with a key. ... London, *1745. Another edition, 1765 .

38. 1748. Graffigny, F. Huguet de. Letters written by a Peruvian Princess, translated from the French [of $\mathrm{F}$. Huguet de Graffigny]. London, 1748. Another edition, Dublin, *1748. Another translation, The Peruvian Letters, translated from the French, with an 
additional original volume by $R$. Roberts. London, 1774.

39. 1749. Voltaire, F. M. Arouet de.

1749. (a) Zadig, or the Book of Fate, an Oriental History, translated from the French original of $M$. Voltaire, London, printed for John Brindley, etc., *1749 A version by F. Ashmore, London, 1780; another edition, 1794. Also in (1) The Works of $M$. de Voltaire Translated from the French with Notes, Historical and Critical. By T. Smollett, M.D., T. Francklin, M.A., and others, Vols. I.-XXV., London . . . 1761-1765; Vol. XI., . . . London . . . 1762 ; in (2) The Works of M. de Voltaire. Translated from the French with Notes, Historical, critical and Explanatory. By T. Francklin, D.D., Chaplain to his Majesty, and late Greek Professor in the University of Cambridge, T. Smollett, M.D., and others. A new edition, 38 vols., 1778-1761-1781, Vol. XI. . . . London . . . 1779; and in (3) Romances, Tales and Smaller Pieces of M. de Voltaire, Vol. I., . . . London. . . . 1794.

1754. (b) Babouc or the World as it goes. By . . Voltaire. To which are added letters, etc. London, *1754. Also in (1) Works, Vol. XI., 1762; in (2) Works (new edition), Vol. XI., 1779; and in (3) Romances, 1794, all cited above under Zadig.

1762. (c) A Letter from a Turk concerning the Faquirs, and his Friend Bababec, in (1) Works, Vol. XIII., 1762 (?); in (2) Works, new edition, Vol. 
XIII., 1779; and in (3) Romances, 1794, all cited above under Zadig.

1762. (d) History of the Travels of Scarmentado. Written by himself, in (1) Works, Vol. XII., *1762 (?); in (2) Works, new edition, Vol. XII., 1779; and in (3) Romances, 1794, all cited above under Zadig.

1762. (e) Memnon; or Human Wisdom. [Memnon the Philosopher] in (1) Works, Vol. XIII., *1762 (?); in (2) Works, new edition, Vol. XIII., 1779; and in (3) Romances, 1794, all cited above under Zadig. 1763. (f) History of a Good Bramin in (1) Works, Vol. XXVI., *1763; and in (2) Works, new edition, Vol. XIX., 1780, both cited above under Zadig. Also printed separately as follows: The History of a Good Bramin to which is annexed an essay on the reciprocal contempt of nations proceeding from their vanity. London, 1795 [no author or translator given].

1765. (g) The Black and the White, in (1) Works, Vol. XXV., *1765; and in (3) Romances, 1794, both cited above under Zadig.

1769. (h) The Princess of Babylon. London, *1769. Also in (1) Works . . . Vol. XXV., 1770; and in (3) Romances, 1794, both cited above under Zadig.

1774. (i) The White Bull [tr. by J. Bentham], *1774. Also in (3) Romances, 1794, cited above under Zadig.

1774. (j) The Hermit, an Oriental Tale. Newly 
translated from the French of $M$. de Voltaire [being a chapter of Zadig], 1774.

[N.B. - Apparently Voltaire's oriental sketches: André des Touches at Siam, A Conversation with a Chinese, and An Adventure in India, as well as the Letters of Amabed, were not translated into English in the eighteenth century.]

40. 1750. Johnson, Samuel.

Ra. No. 38 , July 28,1750 . Hamet and Raschid.

Ra. No. 65, Oct. 1750. Obidah, the son of Abensima, and the Hermit.

Ra. No. 120, May 11, 1751. Nouradin the Merchant and his son Almamoulin.

Ra. No. 190, Jan. 11, 1752. Morad the son of Hanuth and his son Abonzaid.

Ra. Nos. 204, 205, Feb. 29, March 3, 1752. Seged, Lord of Ethiopia.

1759. The Prince of Abissinia [sic], a Tale [= Rasselas]. London, 1759. Second edition, 1759; another edition, Dublin, $1759 ;. .$. ninth edition, 1793.

Id. No. 75, Sept. 22, 1759. Gelalledin.

Id. No. 99, March 8, 1760. Ortogrul of Basra.

Id. No. 101, March 22, 1760. Omar, Son of Hassan.

41. 1750? The History of Abdallah and Zoraide, or Filial and Paternal Love. . . . To which is added The Maiden Tower or a Description of an Eastern Cave, Together with Contentment, a Fable. London *(1750?). 
42. 1752. Hawkesworth, John.

Adv. No. 5, Nov. 21, 1752. The Transmigrations of a Soul.

Adv. Nos. 20, 21, 22, Jan. 13, 16, 20, 1753. The Ring of Amurath.

Adv. No. 32, Feb. 24, 1753. Omar the Hermit and

Hassan.

Adv. No. 72, July 14, 1753. The Story of Amana and Nouraddin.

Adv. No. 76, July 28, 1753. The Story of Bozaldab. Adv. No. 91, Sept. 18, 1753. Yamodin and Tamira. Adv. No. 114, Dec. 8, 1753 . Almet the Dervise.

Adv. No. 132, Feb. 9, 1754 . Carazan.

1761. Almoran and Hamet: an Oriental Tale. London, 1761, 2 vols. Second edition, London, 1761; another edition, 1780; another, London (1794?).

43. 1753. Moore, E.

Wo. No. 40, Oct. 4, 1753. Prince Ruzvanchad and the princess Cheheristany, The Infelicities of Marriage. 44. 1754. Cambridge, Richard Owen.

(a) Wo. No. 72, May 16, 1754 . Princess Parizade.

(b) The Fakeer, a Tale [in verse], - 1756.

45. 1754. Colman and Thornton.

Con. No. 21, June 20, 1754. Story of Tquassaouw and Knonmquaiha.

46. 1754. Le Camus, A. Abdeker, or the art of preserving beauty. Translated from an Arabic manuscript [or rather from the French of A. Le Camus]. London, *1754. Another edition, Dublin, 1756.

47. 1754. Murphy, Arthur, Esq. Works of A.Murphy 
in 7 volumes. London, 1786 . Vol. VI. contains the Gray's Inn Journal, in No. 64 of which, Jan. 5, 1754, is a tale (entitled, Aboulcasem of Bagdad), said to be by "my friend Capt. Gulliver."

48. 1755. Transmarine, Mr. [pseud.]. The Life and surprizing [sic] Adventures of Friga Reveep ... Written in French by himself and translated into English by Mr. Transmarine, *1755. For full title, cf. pp. 48, 49, ante.

49. 1757. Walpole, Horace.

(a) A Letter from Xo-Ho, a Chinese Philosopher at London to his friend Lien Chi at Peking, *1757.

(b) Hieroglyphic Tales. Strawberry Hill, *1785. 50. 1760. Goldsmith, Oliver.

(a) The Citizen of the World, first printed in form of bi-weekly letters in Newbery's Public Ledger beginning Jan. 24, 1760 . First edition, London, *1762. 2 vols. Other editions, 1769, 1774, 1796.

(1765). (b) Asem, an Eastern Tale: or a vindication of the wisdom of Providence in the moral government of the world *(1765 or 1759?). Cf. footnote to p. 125 , ante.

51. 1760. Hamilton, Antoine, Count.

1760. (a) The History of the Thorn-Flower [= MayFlower], in (1) Select Tales of Count Hamilton, Author of the Life and Memoirs of the Count de Grammont, Translated from the French. In two volumes. Vol. I., London ... 1760; and (2) History of May-Flower, A Circassian Tale, second edition . . . Salisbury . . . London, 1796. 
(b) The Ram, in (1) 1760, cited above under The History of the Thorn-Flower.

(c) The History of the Four Facardins, in Vol. II. of (1), 1760, cited above under The History of the Thorn-Flower.

52. 1762. Langhorne, John. Solyman and Almena. Probably $* 1762$. Second edition, London, 1764 ; also edition in 1781; and one in East Windsor, Connecticut, 1799.

53. 1764. Ridley, James, Rev., Chaplain to the East India Company [Morell, Sir C. = pseud.]. Tales of the Genii; or . . . Delightful Lessons of Horam, the Son of Asmar . . . tr. from the Persian Manuscript by Sir C. Morell, 1764. 2 vols. Also editions 1780, $* 1785, * 1794$.

\section{1764. Marmontel, J. F.}

1764. (a) Soliman II. in (1) Moral Tales by M. Marmontel, *1764-1766 (?). Vol. I. . . . London . . . *1764; in (2) Moral Tales, by M. Marmontel. In three Volumes. Vol. I., Edinburgh, 1768; in (3) Moral Tales, by M. Marmontel Translated from the French, by C. Dennis and R. Lloyd. In three Volumes. Vol. I., London ... 1781; in (4) another edition of (3) Vol. I., Manchester . . . [1790 (?)]; in (5) Moral Tales by M. Marmontel. Translated from the French. In two Volumes. Vol. I. Cooke's edition . . . London . . . (1795); and in (6) Moral Tales by M. Marmontel. Vol. I. A new edition ... London . . . 1800.

1766 (?). (b) Friendship put to the Test in (1) Vol. 
III. *(1766?) of (1) cited above under Soliman II.; in (2) Vol. III. (1768) of (2) cited above under Soliman II.; in (3) Vol. III., 1781, of (3) cited above under Soliman $I I . ;$ in $(4)=(4),(1790$ ?), cited above under Soliman II.; in (5) $=(5),(1795)$, cited above under Soliman II.; in (6) Marmontel's Tales, Selected and abridged for the Instruction and Amusement of Youth, by Mrs. Pilkington ... London . . 1799; and in $(7)=(6), 1800$, cited above under Soliman II.

1799. (c) The Watermen of Besons, in (6) cited above under Friendship put to the Test.

55. 1767. [Kelly, Hugh.]

Ba. June 18, [1767]. Orasmin and Elmira, an Oriental Tale. Also printed in Harrison's British Classicks, Vol. VI., London, $* 1794$.

56. 1767. Sterne, Laurence. The Bramine's Journal.

Written 1767, unpublished Ms. in the Additional Ms. 34,527, in British Museum.

57. 1767. [Sheridan, Mrs. Frances (Chamberlaine).]

The History of Nourjahad. By the editor of Sidney Biddulph; Dublin, $* 1767$. Other editions, London, 1788, and 1792.

58. 1769. Smollett, Tobias G.

1769. (a) The History and Adventures of an Atom by Nathaniel Peacock [i.e. T. Smollett]. London, 2 vols., *1749 [1769]. Tenth edition, London, 2 vols., 1778 ; Edinburgh, 1784 ; London, 1786.

1773. (b) The Orientalist: A Volume of Tales after the Eastern Taste. By the Author of Roderick 
Random, Sir Lancelot Greaves, \&c., and others . . . Dublin, *1773.

59. 1769. Musgrave, Sir W. The Female Captive [i.e. Mrs. Crisp] a Narrative of Facts which happened in Barbary in 1756 written by herself. London, *1769, 2 vols.

60. 1769. D'Alenzon Mons. The Bonze or Chinese Anchorite, an Oriental Epic Novel Translated from the Mandarine Language of Hoamchi-vam, a Tartarian Proselite, by Mons. D'Alenzon. . . . London, *1769, 2 vols. [also 1770 ?]. Cf., for full title, p. 126, n. 1 , ante.

61. 1770. Chatterton, Thomas.

(a) Narva and Mored, an African Eclogue, first printed in London Magazine, May, *1770; and reprinted in the Miscellanies, *1778.

(b) The Death of Nicou, an African Eclogue, first printed in London Magazine, June, *1770; and reprinted in the Miscellanies, *1778.

(c) Heccar and Gaira, an African Eclogue, printed in the Supplement to the Miscellanies, *1784; (written Jan. 1770).

62. 1774. Vaucluse, Made Fauques [or Falques] de. The Vizirs, or the Enchanted Labyrinth, an Oriental Tale. London, *1774, 3 vols.

63. 1774. Johnstone, Charles.

(a) The History of Arsaces, Prince of Betlis, by the editor of Chrysal. London, $* 1774$.

(b) The Pilgrim, or a Picture of Life, in a series of letters written mostly from London by a Chinese 
philosopher to his friend at Quang-Tong, containing remarks upon the Laws, Customs and Manners of the English and other Nations . . L London *[1775], 2 vols. Other editions, London, 1775; Dublin, 1775.

64. 1776. Irwin, Eyles.

(a) Bedukah, or the Self-Devoted. An Indian Pastoral. By the Author of Saint Thomas's Mount. . . . London . . .*1776.

(b) Eastern Eclogues; Written during a Tour through Arabia, Egypt, and other parts of Asia and Africa, In the Year 1777, . . L London, . . *1780. [Contents: Eclogue I. Alexis: or The Traveller. Scene: The Ruins of Alexandria. Time: Morning ... Eclogue II. Selima, or the Fair Greek. Scene: A Seraglio in Arabia Felix. Time: Noon ... Eclogue III. Ramah; or the Bramin. Scene: The Pagoda of Conjeveram. Time: Evening ... Eclogue IV. The Escape, or, the Captives. Scene: The Suburbs of Tunis. Time: Night. ... .]

65. 1779. Richardson, Mr. "Professor of Humanity at Glasgow."

Mir. No. 8, Feb. 20, 1779. The Story of the Dervise's Mirror.

66. (178-?) Moir, The Rev. J. Gleanings, or Fugitive Pieces, London *(178-?), [contains Hassan]. 67. 1782. Scott, John (d. 1783). Oriental Eclogues in volume entitled The Poetical Works of John Scott, London, *1782. [The Arabian Eclogue in this collection was written by 1777 .] 
68. 1782. Scott, Helenus, M.D. The Adventures of a Rupee wherein are interspersed . . . anecdotes Asiatic and European. London, $* 1782$.

69. 1783. Chilcot, Harriet (afterward Mezière). Ormar and Zabria; or the Parting Lovers, an Oriental Eclogue, in volume entitled Elmar and Ethlinda, a Legendary Tale and Adalba and Ahmora, an Indian [ = Peruvian] Tale: with other pieces ... London . . . 1783 .

70. 1785. Reeve, Clara. The Progress of Romance, through Times, Countries and Manners, with Remarks on the good and bad effects of it, on them respectively, in a course of evening conversations. By C.R., author of the English Baron, The Two Mentors, etc. . . . Dublin, *1785 [contains The History of Charoba, extracted from the History of Ancient Egypt, Translated by J. Davies, *1672, from the French of Monsieur Vattier, written originally in the Arabian tongue by Murtadi. [Cf. Part II. of this Bibliography, No. 48.] Clara Reeve modernized the language of Davies's translation somewhat].

71. (1785?) Confucius the Sage (pseud.). The Oriental Chronicles of the times; being the translation of a Chinese manuscript supposed to have been written by Confucius the Sage, London *(1785?).

72. (1785?) Cumberland, Richard.

Obs. No. 14 (1785 ?), Abderama.

73. 1786. Beckford, William.

(a) History of the Caliph Vathek. English, *1786; French, $* 1787$. 
(1) The title-page of the first English edition reads: An Arabian tale from an unpublished $m s$., with notes critical and explanatory, London, 1786. On p. v, another title is given: The History of the Caliph Vathek, with notes. The notes were by the translator, Samuel Henley, D.D.

(2) The book had been written between Jan. 1782 and Jan. 1783, in French by Beckford, and was published in French by him in 1787, one edition at Lausanne, another at Paris. [Cf. Part II. of this Bibliography, No. 5, (1), Garnett's edition.]

(b) The Story of Al Raoui - a tale from the Arabick. London, *1799. Given in Memoirs of $W m$. Beckford by C. Redding. London, $* 1859$. Vol. I., p. 217.

74. 1786. The Baloon, or Aerostatic Spy. A Novel containing a series of adventures of an aerial traveller [contains the Eastern Tale of Hamet and Selinda]. London, *1786. 2 vols.

75. 1787. Bage, Robert. The Fair Syrian (a novel), *1787. See La Belle Syrienne, Roman en trois parties; par l'auteur du Mont-Henncth et des Dunes de Barrham. Traduit de l'Anglois . . *1788.

76. 1788. The Disinterested Nabob, a novel interspersed with genuine descriptions of India, its manners and customs. London, *1788. 3 vols. [Second edition.]

77. 1789. Berquin, Arnaud. The Blossoms of Morality, - by the Editor of the Looking-Glass for the Mind. London, *1789. Also, 1796. 
78. (1790?) Cooper, J. The Oriental Moralist or the Beauties of the Arabian Nights Entertainments. Translated from the original [i.e. from Galland's French version] and accompanied with suitable reflections adapted to each story by the Rev. Mr. Cooper, author of the History of England, etc., London*(1790?). Cf. also The Beauties of the Arabian Nights Entertainments consisting of the most entertaining Stories, London, 1792.

79. 1790. Knight, Ellis Cornelia. Dinarbas, a Tale: being a continuation of Rasselas, Prince of Abissinia [sic], London, $* 1790$. Third edition, London, 1793; fourth edition, London, $* 1800$. Also printed in same volume with S. Johnson's Rasselas . . . Greenfield, Mass., 1795.

80. 1790. Caraccioli, Louis Antoine de. Letters on the Manners of the French . . w written by an Indian at Paris. Translated from the French by Chas. Shillito. Colchester, $* 1790$.

81. 1792. [New Arabian Nights.] Arabian Tales, or a continuation of the Arabian Nights Entertainments ... newly tr. from the original Arabic into French by Dom Chavis . . . and M. Cazotte . . and tr. from the French into English by Robert Heron, Edinburgh and London, *1792. 4 vols. Another edition, London, 1794, 3 vols.

82. (1795?) The Arabian Pirate, or authentic history and fighting adventures of Tulagee Angria [a chapbook], Newcastle.

83. (1795?) The Trial and Execution of the Grand 
Mufti, from an ancient Horsleian manuscript, found in the Cathedral of Rochester. . . London *(1795?). 84. 1796. The Siamese Tales, Being a Collection of Stories told to the son of the Mandarin Sam-Sib, for the Purpose of Engaging his mind in the Love of Truth and Virtue, with an historical account of the Kingdom of Siam. To which is added the Principal Maxims of the Talapoins. Translated from the Siamese, London, 1796. Another edition, Baltimore . . . 1797.

85. 1796. [Mathias, T. J.] The Imperial Epistle from Kien Long, Emperor of China to George III., King of Great Britain in the year 1794. Translated into English from the original Chinese ... [pseudo-oriental satire in verse,] London, $* 1796$. Other editions, 1798, 1802; and Philadelphia, 1800.

86. 1796. Klinger, F. M. von. The Caliph of Bagdad, Travels before the Flood, an Interesting Oriental record of men and manners in the antediluvian world, interpreted in fourteen evening conversations between the Caliph of Bagdad and his court, tr. from Arabic [ = translated from the German of F. M. von Klinger], London, *1796. Cf. also No. 93 below, Lewis: Amorassan.

87. 1797. Addison, Mr. Interesting Anecdotes, Memoirs, Allegories, essays and poetical fragments, tending to amuse the fancy and inculcate morality, London, *1797. 16 vols.

88. 1799. Du Bois, Edward. The Fairy of Misfortune; or the Loves of Octar and Zulima, an Eastern Tale 
Translated from the French by the Author of a Piece of Family Biography. The Original of the above Work is supposed to be in the Sanskrit in the Library of the Great Mogul. London, *1799.

89. 1800. Pilkington, Mrs. [Mary P.].

(a) The Asiatic Princess, a tale. London, *1800. 2 vols.

(b) A Mirror of the Female Sex. Historical Beauties for Young Ladies, intended to lead the female mind to the Love and Practice of Moral Goodness, Designed Principally for the use of Ladies Schools: London, *1804. [Third Edition] contains The Governor's wife of Minchew; The Princess of Jaskes; The Empress of China; Amestris, Queen of Persia; Inkle and Yarico [West-Indian, not oriental, taken from Addison, $S p$. No. 11, March 13, 1710-1711].

90. (1800?) Day, Thomas. Moral Tales by Esteemed Writers [contains The Grateful Turk], London *(1800?).

91. 1802. Crookenden, Isaac. Romantic Tale. The Revengeful Turk or Mystic Cavern. London, *1802. 92. 1804. Edgeworth, Maria. Popular Tales [contains Murad the Unlucky] —, 1804; second edition, London, 1805.

93. 1808. Lewis, Matthew Gregory. Romantic Tales. London, *1808, 4 vols. Contains The Anaconda, an East Indian Tale, in Vol. II. ; The Four Facardins, an Arabian tale [in part a translation, and in part an original continuation by Lewis, of Hamilton's 
tale, Les Quatre Facardins] in Vols. II. and III.; and Amorassan or the spirit of the frozen ocean, an Oriental Romance [in part a close translation from Der Faust der Morgenländer by F. M. von Klinger] in Vol. IV. 


\section{APPENDIX B. II.}

BOOKS OF REFERENCE, CRITICAL, HISTORICAL, ETC.

An alphabetical list of the books most useful in a study of this subject. Standard references of obvious value, e.g. the Dictionary of National Biography, Boswell's Johnson, Chalmers's English Poets, Lane's Arabian Nights, etc., are, with a few exceptions, omitted.

1. Arabian Nights.

(a) Burton, Sir Richard F. A Plain and literal translation of the Arabian Nights' Entertainments, now entitled the Book of the Thousand Nights and a Night, with introduction, explanatory notes on the manners and customs of Moslem men and a terminal essay upon the history of the nights (in 10 vols.), Benares, 1885. Printed by the Kamashastra Society for private subscribers only. Cf. especially in Vol. X., Burton's Terminal Essay, and W. F. Kirby's Bibliography of the Thousand and One Nights and their imitations.

(b) Payne, John. The Book of the thousand nights and one night ... done into English prose and verse . . . by John Payne. New York, 1884. 9 vols. (Villon Society Publications; Vols. III.-IX., published in London.) Cf. especially essay at end 
ravishing delights of music, both instrumental and vocal. . . . I really thought myself in paradise."

Page 252, n.4, Southey. Cf. Thalaba the Destroyer. In the Preface to the fourth edition, Cintra, 1800, quoted on p. 6 of Vol. IV., Poetical Works of R. Southey, Boston, 1880, Southey writes: "In the continuation of the Arabian Tales, the Domdaniel is mentioned, a seminary of evil magicians, under the roots of the sea. From this seed the present romance has grown."

Page 252, n. 4, James Thomson (1634-1882). Cf. Poetical Works of James Thomson, edited . . by B. Dobell in 2 vols., London, 1895, Vol. II., p. 109, The City of Dreadful Night. Thomson says, p. 442, note 3 , "The city of the statues is from the tale of Zobeide in the History of the Three Ladies of Bagdad and the Three Calendars. This episode and the account of the Kingdoms of the Sea in Prince Beder and — impressed my boyhood more powerfully than anything else in the Arabian Nights."

Page 253, n. 1, Wordsworth. Cf. The Prelude, Book V. The Poctical Works of William Wordsworth, edited . . . by E. Dowden in 7 vols., 1.460 et seq., Vol. VII., London, 1893.

“A precious treasure had I long possessed,

A little vellow, canvas-covered book, A slender abstract of the Arabian Tales; And, from companions in a new abode, When first I learnt, that this dear prize of mine Was but a block hewn from a mighty quarry That there were four large volumes, laden all With kindred matter, 'twas to me, in truth, A promise scarcely earthly. Instantly, 
With one not richer than myself, I made

A covenant that each should lay aside

The moneys he possessed, and hoard up more,

Till our joint savings had amassed enough

To make this book our own. Through several months,

In spite of all temptation, we preserved

Religiously that vow; but firmness failed,

Nor were we ever masters of our wish.

And when thereafter to my father's house

The holidays returned me, there to find

That golden store of books which I had left,

What joy was mine! How often ...

For a whole day together, have I lain

Down by thy side, O Derwent! murmuring stream,

On the hot stones, and in the glaring sun,

And there have read, devouring as I read,

A gracious spirit o'er this earth presides, And o'er the heart of man : invisibly It comes, to works of unreproved delight, And tendency benign, directing those Who care not, know not, think not what they do. The tales that charm away the wakeful night In Araby, romances; legends penned For solace by dim light of monkish lamps; Fictions, for ladies of their love, devised By youthful squires; adventures endless,

Dumb yearnings, hidden appetites, are ours, And they must have their food. Our childhood sits, Our simple childhood, sits upon a throne That hath more power than all the elements.

Forgers of daring tales! we bless you then. Imposters, drivellers, dotards, as the ape Philosophy will call you: then we feel With what, and how great might ye are in league, Who make our wish, our power, our thought a deed, 
An empire, a possession, - ye whom time And seasons serve; all Faculties to whom Earth crouches, the elements are potter's clay, Space like a heaven filled up with northern lights, Here, nowhere, there, and everywhere at once."

Page 253, n. 1, Scott. Cf. Autobiography in Lockhart's Life of Scott, in five vols., Vol. I., p. 29, Boston, 1902.

"In the intervals of my school hours I had always perused with avidity such books of history or poetry or voyages and travels as chance presented to menot forgetting the usual, or rather ten times the usual quantity of fairy tales, eastern stories, romances, \&c. These studies were totally unregulated and undirected. My tutor thought it almost a sin to open a profane book or poem." Cf. also references such as that in Waverley, Chap. V., to Prince Hussein's tapestry, and "Malek's flying sentry box"; and in the Introduction to Quentin Durward to the "generous Aboulcasem."

Page 253, n. 1, Dickens. (1) David Copperfield, Chap. IV. "My father had left a small collection of books. . . . From that blessed little room, Roderick Random, Peregrine Pickle, Humphrey Clinker, Tom Jones, The Vicar of Wakefield, Don Quixote, Gil Blas, and Robinson Crusoe, came out, a glorious host, to keep me company. They kept alive my fancy, and my hope of something beyond that place and time [his dreary childhood], - they, and the Arabian Nights and the Tales of the Genii, - and did me no harm."

(2) When a child, Dickens wrote a tragedy called 
Misnar, the Sultan of India, founded on the Tales of the Genii. See Life of Dickens by John Forster, Vol. I., pp. 7, 29, 34; also Chauvin, op. cit., IV., p. 11.

Page 253, n. 1, Thackeray. Cf. (1) Vanity Fair, Chap. V. "On a sunshiny afternoon . . . poor William Dobbin . . . was lying under a tree in the playground, spelling over a favorite copy of the Arabian Nights - apart from the rest of the school - quite lonely and almost happy.... Dobbin had for once forgotten the world and was away with Sinbad the Sailor in the Valley of Diamonds or with Prince Ahmed and the Fairy Peribanon in that delightful cavern where the prince found her, and whither we should all like to make a tour." Chap. III. "She [Becky] had a vivid imagination; she had, besides, read the Arabian Nights and Guthrie's Geography."

(2) The Virginians, Chap. XXIII. Hetty Lambert "brought out 'The Persian Tales' from her mamma's closet." Chap. XXX. Harry Warrington writes home of reading "in French the translation of an Arabian Work of Tales, very diverting."

(3) Roundabout Papers. In the paper "On a Lazy, Idle Boy," Thackeray refers to "a score of whitebearded, white-robed warriors, or grave seniors of the city, seated at the gate of Jaffa or Beyrout, and listening to the story teller reciting his marvels out of The Arabian Nights."

(4) Eastern Sketches contains many references to the pleasure Thackeray has always taken in the Arabian Nights, e.g. pp. 338, 339, of Works, Vol. X. 


\section{APPENDIX B. I.}

\section{CHRONOLOGICAL TABLE}

A list of the more important oriental tales published in English during the period under consideration. The order of arrangement is determined by the date of the earliest edition extant. The works of each author are grouped under his name. Editions given immediately after the titles are first editions unless otherwise stated. Editions starred are those referred to in the text or notes.

Abbreviations: Sp. $=$ Spectator; Gu. $=$ Guardian; $\mathrm{Fr}_{\mathbf{r}}=$ Freeholder $;$ Ra. $=$ Rambler $;$ Adv. $=$ Adventurer $;$ Wo. $=$ World ; Con. $=$ Connoisseur $;$ Ba. $=$ Babler $; \mathrm{Id} .=$ Idler; Mir. $=$ Mirror; Obs. $=$ Observer $;$ tr. $=$ translated .

1. 1687. Marana, Giovanni Paolo. Letters writ by a Turkish Spy, who liv'd five and forty years... at Paris: giving an Account ... of the most remarkable transactions of Europe ... from 1637 to 1682 [tr. from French, by W. Bradshaw, and edited by Robert Midgley, M.D.], 8 vols., London, 16871693. Twenty-second edition, $1734 ; \ldots$ edition, * 1748; twenty-sixth edition, 1770.

2. 1700, Brown, Thomas. Amuscments Serious and Comical Calculated for the Meridian of London, separately published in 1700; and also in the Works of Thomas Brown, in three volumes, with a Character of the author by James Drake, M.D., *1707-1708. 
Cf. the four volumes in the Boston Athenæum; (a) the title-page of the first volume reads, The Works of Thomas Brown, Serious, Moral, Comical and Satyrical In Four Volumes, containing Amusements [then follows table of contents of all four volumes]. To which is prefixed a Character of Mr. Brown and his Writings, by James Drake, M.D. The Fourth edition, Corrected, with large Additions, and a Supplement, London. Printed for Samuel Briscoe, 1715; (b) the title-page of the third volume reads, The Third Volume of the Works of Mr. Tho. Brown, Being Amusements, Serious and Comical, Calculated for the Meridian of London. Letters Serious and Comical to Gentlemen and Ladies. Eneas Sylvius's Letters in English. A Walk around London and Westminster, Exposing the Vices and Follies of the Town. The Dispensary, a Farce. The London and Lacedemonian Oracles. The Third Edition, with large Additions. London, Printed for Sam. Briscoe, and sold by J. Morphew near Stationers' Hall,* 171- [date imperfect, conjecture: 1711$]$. In the last-named volume, " $A$ Walk around London and . . . the Town," p. 244, is entitled also, The Second Part of the Amusements Serious and Comical.

3. 1700. [Avery, John]?

(a) The Life and Adventures of Captain John Avery ... now in possession of Madagascar written by a person who made his escape from thence, 1700.

(b) The King of the Pirates, being an account of the Famous Enterprises of Captain Avery, the Mock 
King of Madagascar, with His Rambles and Piracies, wherein all the Sham Accounts formerly publish'd of him, are detected. In two Letters from Himself: one during his Stay at Madagascar and one since his Escape from thence, London, 1720. [According to J. K. Langton in Dict. Nat. Biog. article, "John Avery," $(b)$ has been attributed to Defoe, and both (a) and (b) are "fiction, with scarcely a substratum of fact "].

4. Between 1704 and 1712. Arabian Nights Entertainments: consisting of One Thousand and One Stories, told by the Sultaness of the Indies, to divert the Sultan from the Execution of a bloody vow . . ., containing a better account of the Customs, Manners, and Religion of the Eastern Nations, viz.: Tartars, Persians and Indians, than is to be met with [in] any Author hitherto published. Translated into French from the. Arabian MSS. by M. Galland, ... and now done into English from the third Edition in French. . . . The fourth Edition, London, Printed for Andrew Bell, In 12 [vols. 1-6], *1713-1715. First edition, date unknown; second edition, *1712; edition called the fourteenth edition, London, $* 1778$, 4 vols. [ $=$ " the oldest edition which I have seen containing the latter half of Galland's version." W. F. Kirby in App. II., p. 467, Vol. X., of Burton's Arabian Nights, Benares, 1884].

5. 1705. Defoe, Daniel.

(a) The Consolidator: or Memoirs of Sundry Transactions from the World in the Moon, Translated 
from the Lunar Language. By the Author of the True-Born Englishman, London, . . * *1705.

(b) The Farther Adventures of Robinson Crusoe, London, *1719.

(c) A System of Magic, London, *1726.

6. 1707. Arimant and Tamira; an eastern tale [in verse] In the manner of Dryden's fables; By a gentleman of Cambridge. London, 1707.

7. 1708. Turkish Tales; consisting of several Extraordinary Adventures: with the History of the Sultaness of Persia and the viziers. Written Originally in the Turkish Language by Chec Zade, for the use of Amurath II., and now done into English. London . . . Jacob Tonson, *1768. Cf. also No. $15(b)$ below: 1714, Persian and Turkish Tales compleat.

8. 1708. Abu Jaafar Ebn Tophail. The Improvement of Human Reason, exhibited in the Life of Hai Ebn Yokdhan; Written in Arabick above 500 years ago, by Abu Jaafar Ebn Tophail. . . . Translated by Simon Ockley..., London ....*1708; another edition, 1711. The first English version was published in 1674, anonymously, with the title " $A n A c$ count of the Oriental Philosophy . . . [etc.]." Cf. Brit. Mus. Catalogue under "Abu Jaafar Ebn Tophail," and Dict. Nat. Biog. under "Geo. Ashwell" (16121695). Cf. for full title of Ockley's translation, pp. 126,127 , ante.

9. (1710?). Ali Mohammed Hadji ( $p s e u d$.$) . A brief and$ merry History of Great Britain, containing an account of the religion, customs . . . etc. of the people, written 
originally in Arabick by Ali Mohammed Hadji. . . . Faithfully rendered into English by A. Hillier, London (1710?). Another edition, $* 1730$.

10. 1711. Bidpai. Principal eighteenth-century versions. (1) Esop Naturalized, in a collection of fables and stories from Esop . . Pilpay and others... London, *1711; another edition, 1771 ; (2) The Instructive and Entertaining Fables of Pilpay, an ancient Indian Philosopher, containing a number of excellent rules for the conduct of persons of all ages. London, 1743. [This is a reproduction of the 1679 version, "Made for the Duke of Gloucester."] Other editions, 1747, 1754; fifth edition, 1775; sixth edition, 1789. Cf. Chauvin, Bibliographie, II., pp. 33, 40, 70, and Table opposite p. 1 . The earliest English version of Bidpai is Sir Thomas North's Morall Philosophie of Doni . . 1570.

11. 1711. Addison, Joseph.

[Sp. No. 50, April 27, 1711. Observations by four Indian Kings.]

Sp. No. 94, June 18, 1711. (1) Mahomet's journey to the seven heavens. (2) The adventures of the Sultan of Egypt.

Sp. No. 159, Sept. 1, 1711. The Vision of Mirza. Sp. No. 195, Oct. 13, 1711. Story of sick king cured by exercise with drugged mallet.

[Sp. No. 237, Dec. 1, 1711. Jewish tradition concerning Moses.]

Sp. No. 289, Jan. 31, 1711-1712. Story of the dervish who mistakes a palace for an inn. 
Sp. No. 293, Feb. 5, 1711-1712. Persian fable of drop of water which became a pearl.

Sp. No. 343, April 3, 1712. Story of Pug the monkey. Sp. No. 349, April 10, 1712. Story of courageous Muli Moluc, Emperor of Morocco.

Sp. No. 511, Oct. 16, 1712. (1) Persian marriageauction. (2) Merchant who purchased old woman in a sack.

Sp. No. 512, Oct. 17, 1712. Story of Sultan Mahmoud and his vizier.

Sp. No. 535, Nov. 13, 1712. Story of Alnaschar.

Gu. No. 99, July 4, 1713. Persian story of just sultan.

Gu. No. 167, Sept. 22, 1713. Story of Helim and Abdallah.

Sp. No. 557, June 21, 1714. Letter to the King of Bantam.

Sp. Nos. 584 and 585, Aug. 23 and 25, 1714. Story of Hilpa, Harpath, and Shalum.

Fr. No. 17, Feb. 17, 1716. Persian Emperor's riddle.

12. 1712. Unknown Contributors to Guardian and Spectator.

Gu. No. 162, Sept. 16, 1712. Story of Schacabac and the Barmecide.

Sp. No. 578, Aug. 9, 1714. Story of Fadlallah and Zemroude.

Sp. No. 587, Aug. 30, 1714. Story of Mahomet, Gabriel, and the black drop of sin.

Sp. No. 604, Oct. 8, 1714. Vision at Grand Cairo. Sp. No. 631, Dec. 10, 1714. Story of the dervise who forgot to wash his hands. 
13. 1713. Pope, Alexander.

Gu. No. 61, May 21, 1713. Fable of the traveller and the adder.

14. 1712. Steele, Sir Richard.

$S p$. No. 545, Nov. 25, 1712 . Letter from the Emperor of China to the Pope.

Gu. No. 148, Aug. 31, 1713. Story of the Santon Barsisa.

15. 1714. Persian Tales.

(a) The Thousand and One Days, Persian Tales. Translated from the French by $\mathrm{Mr}$. Ambrose Philips. London, *1714-1715. [Cf. Chauvin, Bibliographie, IV., pp. 123-127.] Third edition, 1722 ; fifth, 1738; sixth, 1750; *seventh, 1765; other editions, 1781, 1783 .

(b) The Persian and the Turkish Tales compleat [sic] Translated formerly from those languages into French [or rather compiled] by $M$. Pétis de la Croix ... [assisted by A. R. Le Sage] and now into Englsh [sic] from that translation by . . Dr. King, and several other hands. To which are added; Two letters from a French Abbot to his friend at Paris, giving an account of the island of Madagascar; and of the French Embassador's reception by the King of Siam. London, *1714.

(c) Cf. Edward Button, A New Translation of the Persian Tales, London, 1754; and the anonymous Persian Tales designed for use and entertainment, *Coburg, 1779-1781.

16. 1717. Kora Selyn Oglan (pseud.). The Conduct of 
Christians made the sport of Infidels in a letter from a Turkish merchant at Amsterdam to the Grand Mufti at Constantinople on occasion of . . . the late scandalous quarrel among the clergy, $* 1717$.

17. 1720. Brémond, G. De. The Beautiful Turk, Translated from the French original, Printed in the Year 1720. [London.] This is another translation of the French tale by G. de Brémond translated "by B. B." as Hattige or the amours of the King of Tamaran, published in Amsterdam, 1680; and also in Vol. I., *1679 or 1683 (?) in R. Bentley's Modern Novels.

18. 1722. (Dec. 11, 1721.) Parnell, Thomas. The Hermit, printed posthumously in Poems on Several Occasions. - Written by Dr. Thomas Parnell, late Arch-Deacon of Clogher: and published by Mr. Pope. London, *1722 (Dec. 11, 1721). For numerous volumes containing this poem, see Brit. Mus. Catalogue. 19. 1722. Aubin, Mrs. Penelope. The Noble Slaves, or the Lives and Adventures of Two Lords and Two Ladies (in Aubin's Histories and Novels), London, *1722. Another edition, Dublin, (1730); also in Mrs. E. Griffith's collection, 1777.

20. 1722. Mailly [or Mailli], Chevalier de. The Travels and Adventures of three princes of Sarendip. Intermixed with eight delightful and entertaining novels, translated from the Persian [or rather the Italian of Chr. Armeno] into French, an [sic] from thence done into English. London, *1722.

21. 1725. Segrais, J. Regnauld de. Bajazet or The 
Imprudent Favorite, in Five Novels Translated from the French. London, *1725.

\section{1725. Gueullette, Thomas Simon.}

(a) Chinese Tales, or the wonderful Adventures of the Mandarin Fum-Hoam translated from the French [of T. S. Gueullette]. London, 1725. Another translation, Chinese Tales ... Fum-Hoam ... translated by the Rev. Mr. Stackhouse, London, n.d. (Cook's pocket edition of select novels). Another edition, $* 1781$.

(b) Mogul Tales . . . Now first translated into English ... With a prefatory discourse on the usefulness of Romances. London, *1736. Second edition, 1743.

(c) Tartarian Tales, or a thousand and one Quarters of Hours, Written in French by the celebrated $M r$. Guelletee [sic] Author of the Chinese, Mogul and other Tales. The whole now for the first time translated into English by Thomas Flloyd. London, printed for $\mathrm{J}$. and R. Tonson in the Strand, *1759. Another edition, Dublin, printed for Wm. Williamson, Bookseller, at Mæcenas's Head, Bride St., 1764; another edition, London, 1785; printed in the Novelist's Magazine, 1785.

(d) Peruvian Tales related in one thousand and one hours, by one of the select virgins of Cuzco to the Ynca of Peru ... Translated from the original French by S. Humphreys (continued by J. Kelly). Fourth edition. London, 1764. Another edition, 1786 .

23. 1729. Bignon, Jean Paul. Adventures of Abdalla, 
Son of Hanif, sent by the Sultan of the Indies to make a Discovery of the island of Borico . . . translated into French from an Arabick manuscript . . by Mr. de Sandisson [pseud.] . . . done into English by William Hatchett. . . . London, * 1729. Second edition, *1730.

24. 1730. Montesquieu, C. de Secondat, Baron de. Persian Letters Translated by Mr. Ozell. London, *1730. Third edition, 1731; sixth edition, anon., Edinburgh, *1773.

25. 1730. Gomez, Mme. Madeleine Angelique (Poisson) de. Persian Anecdotes; or, Secret memoirs of the Court of Persia. Written originally in French, for the Entertainment of the King, by the celebrated Madame de Gomez, Author of La Belle Assemblée. Translated by Paul Chamberlain, Gent. London *1730. The title in the British Museum Catalogue reads, " The Persian Anecdotes . . . Persia, containing the history of those two illustrious heroes, Sophy-Ismael, surnamed the Great, and Tor, King of Ormus, etc. [Translated from the French by P. Chamberlen.] London, 1730."

26. 1731. [Boles, W.?] Milk for Babes, Meat for Strong Men and Wine for Petitioners, Being a Comical, Sarcastical, Theological Account of a late Election at Bagdad, for Cailiff of that City. Faithfully Translated from the Arabick, and Collated with the most Authentic Original Manuscripts. By the Great, Learned and Most Ingenious Alexander the Copper Smith. . . . Second edition, Cork, $* 1731$. 
27. 1733. [D'Orville, Adrien de la Vieuville.] The Adventures of Prince Jakaya or the Triumph of Love over Ambition, being Secret Memoirs of the Ottoman Court. Translated from the Original French.... London, *1733.

28. 1735. Lyttelton, George, First Baron (1709-1773). Letters from a Persian in England to his friend at Ispahan. London, *1735. Fifth edition, 1774; printed also in Harrison's British Classicks, London, *1787-1793. Vol. I.; and in numerous editions of Lyttelton's Works. See Brit. Mus. Catalogue.

29. 1735. Crébillon, C. P. Jolyot de.

(a) The Skimmer, or the history of Tanzai and Neardarné (a Japanese tale), tr. from the French.-1735. Another edition, 1778.

(b) The Sopha, a moral tale, tr. from the French (a new edition). . . L London, 1781.

30. 1736. The Persian Letters, continued. Third edition, London, *1736 [" erroneously ascribed to Lord Lyttelton," Dict. Nat. Biog.].

31. 1739. Boyer (Jean Baptiste de) Marquis d'Argens. Chinese Letters; being a philosophical, historical, and critical correspondence between a Chinese Traveler at Paris and his countrymen in China, Muscovy, Persia, and Japan. Translated ... into [or rather written in] French by the Marquis d'Argens; and now done into English.... London, *1741.

32. (17-?). Bougeant, G. H. The Wonderful Travels of Prince Fan-Feredin, Translated from the French 
[of G. H. Bougeant, *1735], Northampton, n.d. For full title, cf. p. 213, ante.

33. 1741. Haywood, Mrs. Eliza. The Unfortunate Princess, or the Ambitious Statesman, containing the Life and surprizing [sic] Adventures of the Princess of Ijaveo [Ijaves], Interspers'd with several curious and entertaining Novels. London, $* 1741$.

34. 1742. Collins, William. Persian Eclogues, Written originally for the entertainment of the Ladies of Tauris and now translated, $* 1742$; reprinted $* 1757$ as Oriental Eclogues.

35. 1744. The Lady's Drawing Room . . . interspersed with entertaining and affecting Novels. London, *1744 [contains The History of Rodomond and the Beautiful Indian, and The History of Henrietta de Bellgrave].

36. 1745. Caylus, A. C.P. de Tubières, Comte de. Oriental Tales, collected from an Arabian Manuscript in the Library of the King of France. . . . London, *1745. Another edition (1750?).

37. 1745. Vieux-maisons, Mme. de or Pecquet, A. (?). The Perseis, or secret memoirs for a History of Persia [a political satire], translated from the French with a key. ... London, *1745. Another edition, 1765.

38. 1748. Graffigny, F. Huguet de. Letters written by a Peruvian Princess, translated from the French [of $\mathrm{F}$. Huguet de Graffigny]. London, 1748. Another edition, Dublin, *1748. Another translation, The Peruvian Letters, translated from the French, with an 
Perrault, Charles, xxiii, 228, Robinson Crusoe, 12, 129, 130, 238.

Perseis, 201.

Persian Anecdotes, 200, 201.

Persian Eclogues, 52, 53.

Persian Letters, by Lyttelton. 72 n. 1, 160, 178-186, 190; by Montesquieu, see Lettres Persanes, Les.

Persian Tales, 13-25, 81, 233, 241, 248; see also Pétis de la Croix.

Persian Tales of Inatulla, $92 \mathrm{n.} 1$.

Peruvian Tales, see Gueullette.

Pétis de la Croix, xxiv, 24, 246 ; see also Persian Tales.

Philips, Ambrose, 221, 222, 246; see also Persian Tales.

Pied Piper of Hamelin, The, 34.

Pilkington, Mrs. Mary P., 50.

Pococke, Edward, xxii, 130 n. 2.

Pope, Alexander, 77, 221, 222, 230, 238, 243, 244.

Princess of Babylon, The, 207209.

Progress of Romance, The, 55.

Quatre Facardins, Les, 219, 220.

Ragguagli di Parnaso, 240.

Ram, The, 218, 219.

Rasselas, xv, xxvi, 103, 110, $123,124,140-154,227,232$, 248; see also Dinarbas, 103, 104.

Recollections of the Arabian Nights, 252.

Reeve, Clara, 55, 246 n. 2.

Ridley, Rev. J., 102.

Robber Caliph, The, 42, 44, 45. 242 ; Farther Adventures of, 48.

Romance of an Hour, The, $76 \mathrm{n} .2$.

Romanticism, $x v-x x i i i$, Chap. V.

Romantic Tales, 51.

Santon Barsisa, The, 27, 28, 81.

Scott, John, 52, 54.

Scott, Sir Walter, 253.

Seged, Lord of Ethiopia, 123, 124.

Segrais, J. Regnauld de, Bajazet, 46.

Selima and Azor, 204 n. 2.

Sendebar, xix, 26.

Seven Sages of Rome, The, 26.

Sheridan, Mrs. Frances, 97.

Smollett, T., 203, 252.

Soliman II., 106, 204-207.

Solyman and Almena, 97, 99100.

Southey, Robert, xvii, 42, 54, 70, 236, 251, 252.

Spectator, see Addison and Steele.

Steele, Sir Richard, 27, 79, 170,232 ; see Addison.

Sterne, Laurence, 204.

Stevenson, R. L., 254.

Story of Ali Abrahazen and the Devil, 203.

Story of the Arabian Magician in Egypt, 203.

Sultan, or a Peep into the Seraglio, The, 204 n. 2.

Swift, J., 162, 204 n. 1, 244 ; Gulliver's Travels, 29.

System of Magic, A, 203.

Tales of the Genii, 102, 103.

Tartarian Tales, see Gueullette. Tatler, 79.

Temple, Sir William, 246. 
Tennyson, A., 252.

Thackeray, W. M., 254.

Thalaba, see Southey.

Thomson, James (1832-1882), 252.

Thorn-Flower, 214-217.

Thousand and One Days, see Persian Tales.

Thousand and One Nights, see Arabian Nights.

Tour through England, 200.

Travels and Adventures of the Three Princes of Serendip, 29-31.

Travels of Scarmentado, 207, 210.

Trial and Execution of the Grand Mufti, The, 202.

Turkish Spy, The, xvii, 157$162,228,239$.

Turkish Tales, 25-29, 80, 252.

Unfortunate Princess, The, 52.

Vathek, xvii, xxvi, 37-41, Zadig, 126, 132-138; see also

$\bigvee 43$ n. 1, 61-71, 230,248, 251. Hermit, The.
Vision of Mirza, The, 110, 112-114, 126, 232.

Vizirs, The, 102.

Voltaire, F. M. A. de, 68, 70, 126 ; "contes philosophiques," 132-140, 231, and 144-151 (Candide); satiric tales, 156, 157, 207211, 231.

Walpole, Horace, 29 n. 3, 157, $187,188,220,221,223$, $236,248$.

Watermen of Besons, The, 73, $75,76$.

White Bull, The 207, 209.

Whitehead, William, 224.

Wonderful Travels of Prince Fan-Feredin, The, 213.

Wordsworth, W., 253.

World, 224, 225.

World as It Goes, The, 138140. 


\section{Studies in Comparative Literature}

\section{A HISTORY OF LITERARY CRITICISM IN THE RENAISSANCE}

With Special Reference to the Influence of Italy in the

Formation and Development of Modern Classicism

By JOEL ELIAS SPINGARN

Cloth, I2mo pp. $x i+330 \quad \$ 1.50$, net

ROMANCES OF ROGUERY

An Episode in the History of the Novel

By FRANK WADLEIGH CHANDLER

In Two Parts. - Part I.: “The Picaresque Novel in Spain.”

Cloth, 12mo pp. ix $+483 \quad \$ 2.00$, net

SPANISH LITERATURE IN THE ENGLAND OF THE TUDORS

BY JOHN GARRETT UNDERHILL

$\begin{array}{lll}\text { Cloth, } 12 \mathrm{mo} & \text { pp. } \mathrm{x}+43^{8} \quad \$ 2.00, \text { net }\end{array}$

THE CLASSICAL HERITAGE OF THE MIDDLE AGES

BY HENRY OSBORN TAYLOR

Sometime Lecturer in Literature at Columbia University Author of "Ancient Ideals"

Cloth, I 2 mo pp. xvi $+400 \quad \$ 1.75$, net

THE ITALIAN RENAISSANCE IN ENGLAND

BY LEWIS EINSTEIN

Illustrated Cloth, I2mo $\quad$ pp. xvii $+420 \quad \$ 1.50$, net

THE MACMILLAN COMPANY, Agents

66 Fifth Arenue, New York 


\section{Studies in Comparative Literature}

Platonism in English Poetry of the Sixteenth and Seventeenth Centuries

BY JOHN SMITH HARRISON

Cloth, I2mo pp. xi $+235 \quad \$ 2.00$, net

\section{Irish Life in Irish Fiction}

By HORATIO SHEAFE KRANS

Cloth, I $2 \mathrm{mo}$

pp. vii +338

$\$ 1.50$, net

The English Heroic Play

By LEWIS NATHANIEL CHASE

Cloth, 12mo pp. xii $+250 \quad \$ 2.00$, net

The Oriental Tale in England

By MARTHA PIKE CONANT

${ }^{*}{ }^{*}$ Other numbers of this series will be issued from time to time, containing the results of literary research or criticism by the students or officers of Columbia University, or others associated with them in study, under the authorization of the Department of Comparative Literature.

\section{THE MACMILLAN COMPANY, Agents}

66 Fifth Avenue, New York 


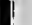





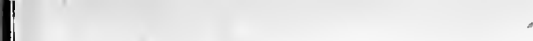
. 



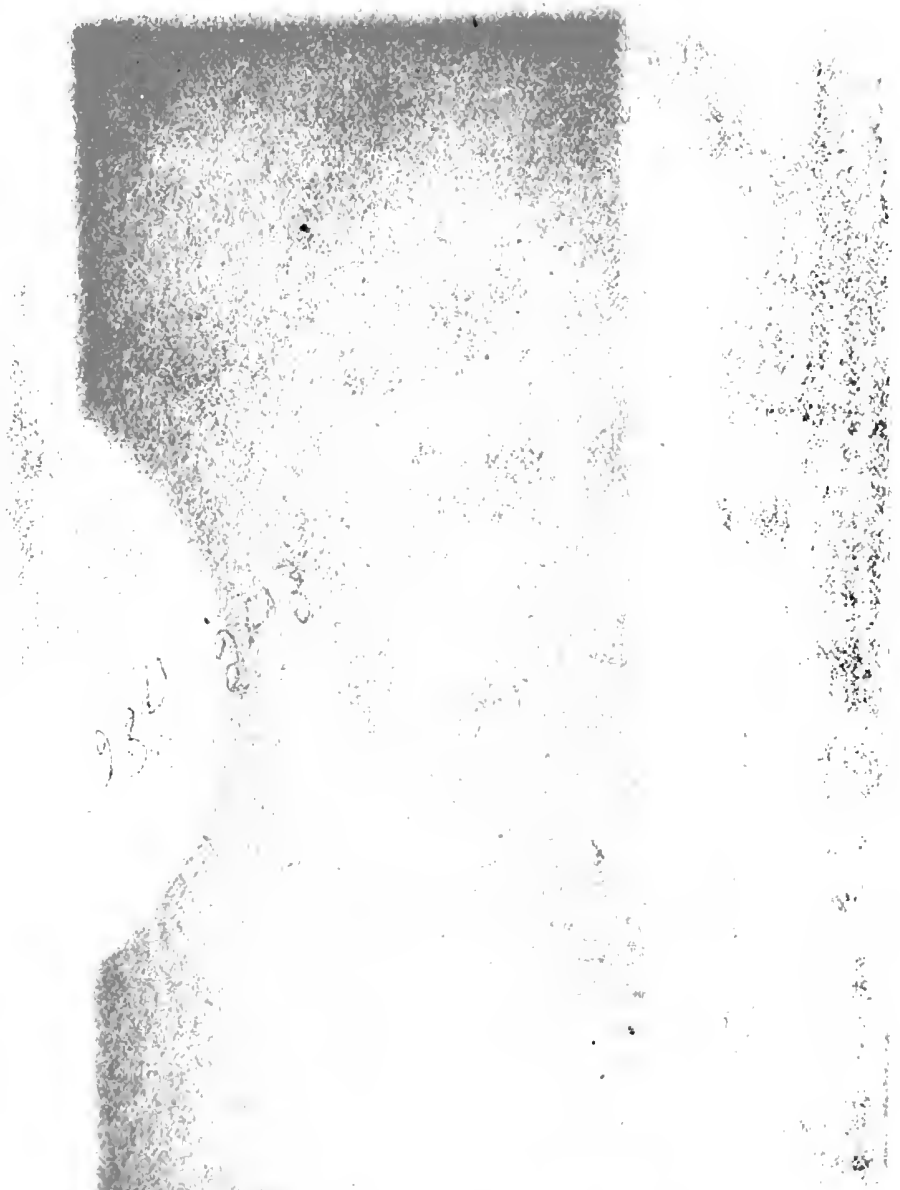


PR

858

0706
Conant, Martha Pike The oriental tale in England

\section{PLEASE DO NOT REMOVE \\ CARDS OR SLIPS FROM THIS POCKET}

UNIVERSITY OF TORONTO LIBRARY 
$!$

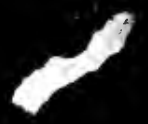

